\title{
SIGMUND MÉNDEZ
}

\section{Reflexiones teóricas de Leonardo da Vinci sobre la "fantasia"}

$\mathrm{E}$ mblemática del Renacimiento, la figura de Leonardo (Vinci, I452-Amboise, I5 I9) representa la expresión cimera de la conciencia artística volcada al mundo como conjunto animado de phainómena, de parousíai visuales para la aprehensión anímica y su representación material. Su obra plástica es, por sí misma, el más elocuente testimonio de esa pasión del ojo ante la realidad. Acompañando el despliegue de sus trabajos pictóricos figura también la rica veta de sus cuadernos de apuntes, que componen la bitácora reflexiva del maestro que deja constancia de su incansable actitud inquisitiva, que se extiende, en un constante crescendo teórico, desde los últimos años de la década de I480 en Milán —aunque aun retrotraíbles a su etapa florentina- hasta su periodo final en Italia. Como es sabido, no llegan a fraguarse en una exposición secuencial y organizada del pensamiento leonardesco, a pesar de que su autor aspiró de cierto a la composición de un Libro di Pittura. ${ }^{\text {I Sin }}$

I. De más larga fortuna ha sido la denominación Trattato della Pittura (París: Appresso Giacomo Langlois, I65I), la célebre editio princeps con las ilustraciones de Nicolas Poussin, texto que parte de un manuscrito a su vez desprendido del Codex Urbinas (Biblioteca Vaticana, lat. I270), editado por vez primera por Guglielmo Manzi, bajo el título Trattato della Pittura (Roma: Stamperia de Romanis, I8I7). Este manuscrito se realizó hacia la década de I540 por cuenta de Giovanni Francesco Melzi ("Meltius"), alumno de Leonardo en el periodo final de su vida y heredero y custodio de sus cuadernos; organizado con base en éstos y quizá — dada su devota fidelidad a los textos leonardescos — siguiendo un plan prescrito por el propio Leonardo, tiene como incipit: "Libro di Pittura, di Messer Lionardo da Vinci, pittore e scultore fiorentino". Véase la "Introduzione" de Pedretti y la "Nota al testo" de Vecce en su edición que restituye este título de índole más quattrocentesca: Leonardo da Vinci, Libro 
embargo, tanto sus reflexiones pictóricas como las de temas científicos diversos conforman —en esa cualidad esencialmente fragmentaria que en buen grado marcó su creación entera - un complejo archipiélago gráfico-sígnico que no deja por ello de constituir, según opinaba Schlosser, "el más grandioso monumento" de la literatura artística italiana ${ }^{2}$ cuya unidad es articulada por las convicciones del artista y la infrangible disciplina de su proceso indagador ante los fenómenos naturales y los secretos del arte. El pintor parece asumir para sí la apertura originaria del lumen naturale del hombre; las notas leonardescas tienen a veces el valor de auténticas "iluminaciones", para usar el término benjaminiano; se les podría llamar "epifanías”, revelaciones vivientes de la naturaleza de las cosas al ojo del artista. Su teoría del arte es, en el sentido más puro del término, theoría: contemplación. Pero supone el penetrante mirar de un pintor, es decir, de un productor de formas cuyo ver es también un hacer; la suya es, por tanto — para usar una expresión de Francisco de Holanda-, una "contemplação activa", 3 una contemplación creadora.

Ciertamente, las reflexiones teóricas leonardescas se dan dentro del primado epistémico de la visión. Ya en el célebre comienzo de la Metafísica, evocado por Leonardo, ${ }^{4}$ Aristóteles señaló que, entre los sentidos, el más estimado de todos es el de la vista..$^{5}$ La razón es de orden epistemológico: la vista es, entre aquéllos, el que nos permite conocer más. ${ }^{6}$ La disputa de los sentidos, protagonizada las más de las veces por la vista y el oído, cubre un extenso

di Pittura. Codice Urbinate lat. I270 nella Biblioteca Apostolica Vaticana, ed. Carlo Pedretti, transcr. Carlo Vecce, vol. I (Florencia: Giunti, I995), II-8I y 83-I23. Para una opinión contrapuesta y problematizadora sobre la organización del Libro, véase Claire Farago, "How Leonardo da Vinci's Editors Organized His Treatise on Painting and How Leonardo Would Have Done It Differently", en Leonard's Writings and Theory of Art, ed. Claire Farago (Nueva York/Londres: Garland, 1999), 417-438.

2. Julius Schlosser,Die Kunstliteratur. Ein Handbuch zur Quellenkunde der neueren Kunstgeschichte (Viena: Anton Schroll \& Co., I924), I63.

3. Francisco de Holanda, Da pintura antigua. Tratado de Francisco de Hollanda. Contém: a) Livro primeiro-parte theorica, b) Livro segundo-Dialogos em Roma, ed. Joaquim de Vasconcellos, $2^{\text {a }}$ ed. (Porto: Renascença Portuguesa, 1930), 66.

4. "Naturalmente li omini boni disiderano sapere". Leonardo da Vinci, Codex Atlanticus [Milán: Biblioteca Ambrosiana], i I gv a, en Leonardo da Vinci, Scritti scelti, ed. Anna Maria Brizio, $2^{a}$ ed. (Turín: Torinese, 1996), 170.

5. Aristóteles, Metaphysica I, 980a23-24, en ed. W. D. Ross (Óxford: Clarendon, 1970).

6. En contraste, Platón indica su principalía acotando sus límites "pues la vista llega a ser en nosotros el más agudo entre los sentidos del cuerpo, donde no se ve el pensamiento". Phaedrus 250d3-4, en ed. I. Burnet (Óxford: Clarendon, I90I). 
recorrido en la historia de Occidente; es posible que aquélla no haya encontrado nunca un apólogo más fervoroso que Leonardo, ${ }^{7}$ para quien el ojo es el "juez universal de todos los cuerpos". ${ }^{8}$ La universalidad de sus posibilidades cognoscitivas es, de esta forma, el fundamento de su principalía: "El ojo, al que se llama ventana del alma, es la vía principal por donde el sentido común puede más copiosa y magníficamente considerar las infinitas obras de la naturaleza". En Leonardo puede encontrarse la cima de esa tendencia de la baja Edad Media y el temprano Renacimiento de exaltar las artes plásticas a través del ojo. Para él, la capacidad misma de la comprensión del hombre parece tener una mediación visual como determinante primario de verdad; como en el verbo griego eido, para Leonardo "mirar" es "comprender"Io y en ello está la llave maestra para penetrar los misterios de la naturaleza.

¿Qué sitio puede ocupar la phantasía dentro de la órbita de un consumado naturalismo científico-artístico? Desde las nociones modernas de aquélla como creación libre de formas más allá de la inmediata realidad sensible, pareciere que no hay mucho lugar a un papel de relieve. Sin embargo, un aspecto significativo de la teoría leonardesca para la comprensión de la phantasía como concepto estético es que puede clarificar, de varios modos, aspectos a veces olvidados de la polivalencia originaria de la palabra y sus ramificaciones semánticas. Pues, en sus primeros momentos, y antes de notoriamente designar

7. Sugería Croce: "e si potrebbe dire che ciò che veramente adora, non è lo spirito, ma l'occhio". Benedetto Croce, "Leonardo filosofo", en Leonardo da Vinci. Conferenze fiorentine (Milán: Fratelli Treves, 1910), 232-233.

8. "universale giudice di tutti i corpi". Leonardo da Vinci, "Il Libro della pittura", Codex Atlanticus, Ior, en Da Vinci, Scritti scelti, I83 y The Literary Works of Leonardo da Vinci. Compiled and Edited from the Original Manuscripts, ed. Jean Paul Richter, 2 vols. (Londres: Sampson Low/ Marston/ Searle \& Rivington, I883), $\$ 52$.

9. "L'occhio, che si dice finestra dell'anima, è la principale via donde il comune senso può più copiosa e magnificamente considerare le infinite opere di natura". Da Vinci, Codex Atlanticus, 99r-v, en Da Vinci, Scritti scelti, 203; The Literary Works, ed. Richter, $\$ 653$ y Da Vinci, Libro di Pittura, $\$$ I9, I42 [ca. I 492]. Luego, quitarse la vista voluntariamente (como Demócrito), por razones de no estorbar su pensamiento, es para Leonardo incuestionable muestra de "pazzia" y acto "stoltissimo". Da Vinci, Libro di Pittura, \$ I6, I4I [ca. I500-I505].

Io. La primacía epistemológica del ver ha sido señalada con agudeza por san Agustín, Confessiones X, 35, 54, en Confessionum libri XIII, vol. 27 de Corpus Christianorum Series Latina, ed. Lucas Verheijen (Turnhout: Brepols, 198I), I84. Heidegger ha recordado, a la luz del inicio de la Metafísica, el pasaje agustiniano en sus reflexiones sobre "la constitución fundamental de la vista" ("Die Grundverfassung der Sicht"); véase Martin Heidegger, Sein und Zeit, I $8^{\mathrm{a}}$ ed. (Tubinga: Max Niemeyer, 200I), I70-17I. 
una facultad interior, el vocablo griego significó "aparición”, "representación”, o, simplemente —y de manera más originaria—, "presentación”, es decir, el aparecer de un objeto como presencia manifiesta inmediatamente dada a los sentidos. Tal es el sesgo principal del significado que muestra su temprano empleo por parte de Platón, quien de hecho llegó a colocar la palabra en términos de equivalencia significativa con la "sensación": "Luego, la apariencia [phantasía] y la sensación [aísthesis] son lo mismo" (Theaetetus I52cI; ed. I. Burnet). Posteriormente, en Aristóteles designará más bien a la percepción interior del objeto in absentia; y, a partir de ahí, se desprenderá a otras esferas que comportan un grado de evocación "libre" de las cosas del mundo, como las producidas por el sueńo. Ahora bien, en el caso de Leonardo encontramos, bajo la nomenclatura de términos asociados como "ingenio" y "sentido común", un conjunto de marcas que esbozan el hacer del artista como producto de las facultades internas que constituyen una bisagra perceptivo-representativa; el espacio conceptual adonde apuntan ha sido, desde la Antigüedad, cubierto por la proteica phantasía, valor que, a través de las propias palabras fantasia e immaginazione, no deja de confirmar su pervivencia semántica en el entorno de la Italia de finales del siglo Xv y principios del Xvi.

\section{La teoría leonardesca de los sentidos interiores}

El procesamiento cognoscitivo de las imágenes llevó a Leonardo a la especulación sobre los "sentidos interiores", cuyas definiciones y localización corporal específica fueron asunto de discusión milenaria para médicos y filósofos. ${ }^{\text {I }}$ En primer término, es conveniente destacar un distingo básico de dos potencias asumido por el artista: por un lado, el sensus communis - concepto de prosapia aristotélica ${ }^{\mathrm{I2}}$ y de largo uso en las teorías del alma medievales y

I I. Sobre este tema, véase la sucinta monografía de E. Ruth Harvey, The Inward Wits. Psychological Theory in the Middle Ages and the Renaissance (Londres: The Warburg Institutel University of London, I975).

I2. Véase sobre todo lo expuesto en el De anima III, I-2, 424b22-427a I6, en ed. W. D. Ross (Óxford: Clarendon, 1984); Aristóteles habla, en primer término, de los “sensibles comunes", es decir, datos no específicos de un sentido particular sino comunes a ellos, como el movimiento, la figura, el tamaño, el número, etcétera (4I8a IO-20); pero también el término puede ser acaso entendido como la "parte sensitiva" unitaria del alma (De sensu et sensibilibus 449a7, en Parva naturalia, ed. W. D. Ross [Óxford: Clarendon, I955]), y realmente a manera de un "sentido 
renacentistas - como colector in praesentia de los varios sentidos; y, por el otro, la imaginatio, imaginativa o phantasía, cuyas imágenes "le nacen" en la interioridad sin la vista del objeto, el cual "entra por el ojo al sentido común, pero la imagen de tal cuerpo no entra en ese sentido, sino nace allí, en el ojo tenebroso". ${ }^{13}$ Tal noción corresponde a la ya para entonces largamente

común" general a partir de la sugerente mención conjunta con el "pensamiento" (De partibus animalium IV, 686azI, en ed. P. Louis [París: Les Belles Lettres, 1956]). Se trata de cierto de un concepto complejo en las reflexiones de Aristóteles y no definidamente caracterizado, cuya particularidad central es, según sugería Ross, la "naturaleza común" a los sentidos particulares (William David Ross, Aristotle [Londres: Methuen, I923], I40). Por su parte, reconociendo que no se trata de un "término técnico" fijado por el filósofo, Gregoric sugiere separar el concepto de "sentido común" de la acción respecto de los "sensibles comunes" (De anima III, I, 425a27), y explicarlo — relacionando De partibus animalium (IV, 686a3 I), De memoria (450a10), en Parva naturalia, ed. Ross, y De anima (III, 7, 43 I b5) - como "the 'sensory capacity of the soul" que "unifies the perceptual and the imaginative capacity" (Pavel Gregoric, Aristotle on the Common Sense [Óxford: Oxford University Press, 2007], 204). Pareciere una interpretación excesiva cuando menos en lo que toca a la phantasía, que si bien requiere de las sensaciones como el noûs de los phantásmata, realiza su operación in absentia (contrariamente a lo que propone el ejemplo en De anima 43Ib5), aunque la definición de 429aI-2 ("un movimiento generado por la sensación en acto"; por ello, como apunta Michael Davis, The Soul of the Greeks. An Inquiry [Chicago/Londres: Chicago University Press, 20I I], 39: "phantasia [...] is ultimately understood as a modification of sense") y el contexto del importante pasaje del De memoria, 450a (discutido con detalle por Gregoric, Aristotle on the Common Sense, 99-I I I) justifiquen este modo extensivo de la "sensación" (aisthesis), acotado o contradicho en otros pasajes (el deslinde en III, 3, 427bi4-I5; o la enunciación de una phantasía logistiké, 433b29; o bien el apunte de Metaphysica IV, 5, Iorob3). Sin embargo, este mismo crítico focaliza la pertinencia del término y el concepto histórico de sensus communis aristotélico a su significado básico en la tradición: "the higher-order perceptual power emerging from the unity of the perceptual capacity of the soul" (Gregoric, Aristotle on the Common Sense, 206). En todo caso, se trata de nociones complejas e inestables (Gregoric acepta, sobre una propuesta de interpretación sistemática de la capacidad sensitiva, que "Aristotle's notion of imagination is notoriously problematic"), como testimonia la milenaria discusión en torno a ellas, donde se estableció el deslinde entre sensus communis y la phantasía de modo confuso o llegó a asumirse su equipolencia total. De modo singular, esa lectura más vasta del sentido aristotélico original se vuelve quizá oportuna respecto del senso comune en Leonardo, cuya principalía alcanza incluso un grado intolerable para aquélla. Por otra parte, nótese que el centro de la "sensación" corresponde, según Aristóteles, al corazón (De partibus animalium II, IO, 656a27-29); la tradición médica desde Alcmeón, sin embargo, impuso a la postre el cerebro como lugar de las funciones superiores, donde ubicaron las teorías medievales al sensus communis como facultad unitaria superior de los sentidos.

I3. "entra per l'occhio al senso comune, ma la immaginazione di tale corpo non entra in esso senso, ma lì nace, in l'occhio tenebroso". Da Vinci, Libro di Pittura, \$ I5, I40 [ca. I500- 
codificada, desde las lecciones aristotélicas, de la phantasía como imago in absentia rei. ${ }^{\text {I }}$

Cabe notar otra variante nominal con la que Leonardo vierte conceptos semejantes:

La pintura te representa al instante su esencia en la virtud visiva, y por el propio medio donde la impresiva recibe los objetos naturales, y aún al mismo tiempo en que se compone la proporcionalidad armónica de las partes que componen el todo, que complace al sentido; y la poesía refiere lo mismo, pero con un medio menos

I505]. O bien, en la poesía no accede la cosa por la vista, "manda le medesime cose al comun senso per la via de l'audito". Da Vinci, Libro di Pittura, \$22, I45 [ca. I490-I 492].

I4. Véase por ejemplo: J. Freudenthal, Über den Begriff des Wortes "Phantasía" bei Aristoteles (Gotinga: Adalbert Rente, I863), I6; Ross, Aristotle, I43; RenéLefebvre, "La crise dela phantasia: originalité des interprétations, originalité d'Aristote”, en De la phantasia à l'imagination, eds. Danielle Lories y Laura Rizzerio (Lovaina/Namur/París/Dudley, Massachusetts: Peeters/ Société des Études Classiques, 2003), 4I. Será un elemento común en las definiciones medievales de la imaginatio, a partir de fuentes como Boecio: "Imaginatio quoque, tametsi ex sensibus uisendi formandique figuras sumpsit exordium, sensu tamen absente sensibilia quaeque collustrat non sensibili sed imaginaria ratione iudicandi". Philosophiae consolatio V, 4 [prosa] 37, 98-IoI; vol. 94 de Corpus Christianorum Series Latina, ed. Ludovicus Bieler (Turnhout: Brepols, 1957), 97; por ejemplo, en un tratado seudo-agustiniano, atribuido a Alcher de Clairvaux: "Imaginatio est ea vis animae, quae rerum corporearum corporeas percipit formas, sed absentes. Sensus namque formas in materia percipit, imaginatio extra materiam: et ea vis quae exterius formata, sensus dicitur, eadem usque ad intimum traducta, imaginatio vocatur [...] Imaginatio est vis animae, quae figuram corporearum rerum absente corpore sine exteriori sensu dignoscit". [Seudo-] san Agustín, De spiritu et anima; XI, vol. 40 de Patrologia Latina (París: J.-P. Migne, I845), col. 786 y XXXVIII, cols. 808-809. Kilwardby: "Nec est intelligendum hic ymaginem acquisitam spiritu sensitiuo de se gignere ymaginem in ymaginatiuum, sed eandem ipsam sentiendo acquisitam efficere sensacionem in presentia sensibilis, et postea ymaginacionem in eiusdem absencia”. De spiritu fantastico, q. 3, I 43, en Robert Kilwardby, On Time and Imagination. De Tempore, De Spiritu Fantastico, ed. Osmund Lewry, Auctores Britannici Medii Aevi 9 (Óxford: The British Academy and Oxford University Press, 1987), 88-89. O bien, santo Tomás: "vis imaginativa format sibi aliquod idolum rei absentis, vel etiam nunquam visae". Summa theologiae I, q. 85, art. 2, ra3; en Opera omnia, vol. 2, Summa contra gentiles, Autographi deleta, Summa theologiae, ed. Roberto Busa (Stuttgart-Bad Cannstatt: Frommann, I980), 3ira. Posteriormente, seguirá siendo un rasgo distintivo de phantasía-imaginatio reconocido como tal en la tradición filosófica europea; el propio Kant señalará: "Die Einbildungskraft (facultas imaginandi) [ist...] ein Vermögen der Anschauungen auch ohne Gegenwart des Gegenstandes". Anthropologie in pragmatischer Hinsicht 25, en Immanuel Kant, Werke, ed. Wilhelm Weischedel, vol. 6 (Fráncfort del Meno: Insel, 1964), 466. 
digno que el ojo, pues lleva a la impresiva más confusamente y con más demora las figuraciones de las cosas nombradas, lo que no hace el ojo, medio verdadero entre el objeto y la impresiva. ${ }^{\text {Is }}$

Según este apunte, la información de los sentidos, ya sea la vista o el inferior oído ("Tanto el ojo es más presto que el oído en su oficio como mejor conserva la semejanza de las cosas impresas en él"), ${ }^{16}$ pasa a la "facultad impresiva". Esta designación es prácticamente exclusiva de Leonardo, y cabe conjeturarla como una derivación de la vis apprehensiva ${ }^{17}$ cuyo valor es "doubtless to emphasize its receptive function" ${ }^{18}$ Dicha "potencia aprehensiva" resulta una denominación plurívoca, con el valor general de las varias facultades o "sentidos interiores", 19 y puede entonces servir para nombrar tanto al sensus y a la

I5. "La pittura ti rapresenta in un subito la sua essenzia nella virtù visiva, e per il proprio mezzo, donde la impressiva riceve li obbietti naturali, et ancora nel medesimo tempo, nel quale si compone l'armonica proporzionalità delle parti che compongono il tutto, che contenta il senso; e la poesía referisce il medesimo, ma con mezzo meno degno che l'occhio, il quale porta nella impressiva più confusamente e con più tardità le figurazioni delle cose nominate che non fa l'occhio, vero mezzo infra l'obbietto e la impressiva [...]" Da Vinci, Libro di Pittura, $\$$ 23, I 46 [ca. I 490-I 492]. También las semejanzas de las cosas en la poesía "non passano alla impressiva per la via della virtù visiva come la pittura”. Da Vinci, Libro di Pittura, $\$ 2, \mathrm{I} 32[c a .1500-1505]$.

I6. "Tanto quanto l'occhio in suo offizio è più presto che l'orecchio, tanto più riserva la similitudine delle cose in esso impresse". Da Vinci, Codex Atlanticus, 25ora, en Da Vinci, Scritti scelti, I80. Además, según Ficino, la belleza es más propia de la vista que del oído: "pulchritudinem magis etiam ad uisum pertinere, quam auditum: quia uidelicet uisus \& lumen similiora intelligentiae sunt quam auditus \& sonus". In Plotinum. In librum de pulchritudine commentarius I, en Marsilio Ficino, Opera, \& quae hactenus extitere, \& quae in lucem nunc primum prodiere omnia..., vol. 2 (Basilea: Ex Officina Henricpetri, I576), I574-I575.

I7. Según sugiere Mary Pardo, "Memory, Imagination, Figuration: Leonardo da Vinci and the Painter's Mind", en Leonard's Writings, ed. Farago, I32 y I49-I50, n. 52.

I8. Charles D. O'Malley y J. B. de C. M. Saunders, Leonardo on the Human Body (Nueva York: Dover, I983), 364.

I9. Incluso de modo teórico, según indica Avicena, es posible plantear la convergencia de las "potencias aprehensivas" en una sola facultad cognoscitiva que aprehende lo inteligible por sí misma y que también subsume en ella los demás “instrumentos” sensibles a su servicio: "an omnes vires apprehendentes sint una vis et an ipsa habeat apprehensiones per seipsam quae sunt intelligibiles, et alias apprehensiones per instrumenta quae sunt diversae secundum diversitatem instrumentorum" (I, IV, 84-87). Avicenna Latinus, Liber De Anima seu sextus De Naturalibus, ed. Simone van Riet, vol. I, Partes I-III (Lovaina: Brill, I972), 70. En todo caso, el término es operativo para los "sentidos interiores", como apunta John Blund: 
imaginatio, uno que aprehende la "cosa presente" y la otra la "cosa ausente", ${ }^{20}$ como al intellectus o la ratio (aquellas facultades captan los singulares, éstas los universales"). ${ }^{21}$ Entonces Leonardo habría adaptado nominalmente para tal efecto un derivado de imprimerelimpressione a partir de la perdurable metáfora de las "impresiones" sensoriales, que proviene de la Antigüedad helénica y perdura en las lenguas modernas. Tratándose de "sensaciones", corresponde a la imagen del anillo impreso en la cera al modo en que la expuso Aristóteles (De anima II, I2, 424aI7-20; De memoria 450a30-32), y al sensus como "potencia aprehensiva de afuera" (vis apprehensiva deforis), que recibiría — según la aplicación de Avicena meditada por John Blund- del ens la prima impressio en el alma. ${ }^{22}$

"Vis autem apprehensiva deintus est sensus communis, et vis ymaginativa, et vis estimativa, et vis memorialis et reminiscibilis" (vI, 6I). Iohannes Blund, Tractatus de anima, eds. D. A. Callus y R. W. Hunt, Auctores Britannici Medii Aevi 2 (Londres: The British Academy/ Oxford University Press, I970), I8.

20. De acuerdo con santo Tomás: "Sed circa apprehensionem sensus sciendum est quod est quaedam vis apprehensiva quae apprehendit speciem sensibilem sensibili re praesente, sicut sensus proprius, quaedam vero quae apprehendit eam re absente, sicut imaginatio; et ideo semper sensus apprehendit rem ut est, nisi sit impedimentum in organo vel in medio, sed imaginatio ut plurimum apprehendit rem ut non est, quia apprehendit eam ut praesentem cum sit absens: et ideo dicit Philosophus in IV Metaphysicae [I4] quod sensus non est dicens falsitatis sed phantasia." Quaestiones disputatae. De veritate, q.I, art. I I, res., en Santo Tomás de Aquino, Le questioni disputate, ed. Roberto Coggi, vol. I, La verità (Questioni I-9) (Bolonia: Edizioni Studio Domenicano, I992), I62. Dicho distingo sobre el sensus como en principio mayor garante de verdad sobre las cosas resultaba, en efecto, pertinente para la visión leonardesca.

2I. "Est autem quaedam vis apprehensiva universalium, scilicet intellectus vel ratio, quaedam autem vis apprehensiva est singularium, scilicet sensus vel phantasia." Quaestiones disputatae. De malo, q. 8, art. 3, res., en Santo Tomás de Aquino, Le questioni disputate, ed. Roberto Coggi, vol. 7, Il male (De malo). Questioni 7-I6 (Bolonia: Edizioni Studio Domenicano, 2003), 200.

22. Según Avicena: "Dicemus igitur quod res et ens et necesse talia sunt quod statim imprimuntur in anima prima impressione" (I, v). Avicena, Liber de Philosophia prima siue Scientia divina I-IV, ed. Simone van Riet, intr. Gérard Verbeke (Lovaina y Leiden: E. Peeters, I977), 3I. De acuerdo con Blund: "Sensus est vis apprehensiva rei presentis in quantum ipsa est presens per inmutatione receptas in instrumento corporeo ab extrinseco advenientes [...] Quod solum singulare sentiatur testantur omnes auctores de sensu loquentes. Sed quod sensus apprehendat universalia videtur posse ostendi. // Ens est prima anime impressio, ut dicit Avicenna, unde per se cadit in intellectum. Quicquid autem in sensum cadit est ens. Quod autem in intellectum cadit, tum est ens tum est non-ens. Ergo potius dicetur quod ens, secundum quod ens cadit in sensum quam in intellectum et ens dicetur prima 
Dicho discrimen, sin embargo, no queda expresado en los modelos generales considerados por el artista. Debe notarse que Leonardo maneja criterios de clasificación de las potencias interiores que pueden considerarse relativamente "originales" respecto de las más tradicionales, como, por ejemplo, la que por esos años ilustró Albrecht Dürer (Caput phisicum [sic]) para el libro de Ludovicus de Prussia (I 498) (fig. I). ${ }^{23}$ En un temprano estudio de cráneo (Codex Windsor, RL I2626r, ca. I487-I489) hay un esquemática representación de los tres ventrículos cerebrales; ${ }^{24}$ al anterior (conectado con los ojos) se le adjudican la imprensiva y el intelletto; al medio (al que se vinculan los oídos) se le atribuyen el senso commune y la volonta; y al posterior, la memoria ${ }^{25}$ (la más estable de las potencias en la movediza cartografía cerebral de la Antigüedad al Renacimiento) (fig. 3). Este cuadro es ciertamente anómalo, por proponer, en primer término, al intelletto en una posición frontal, ${ }^{26}$ cuando, en todo caso,

esse anime impressio secundum sensum et non secundum intellectum. Sed ens est primum universale aggregans omnia in sua intentione universali; ergo universale cadit in sensum" (viII, 84-85). Blund, Tractatus de anima, 23. De haberlas conocido, probablemente hubieran resultado atractivas a Leonardo varias de estas argumentaciones contempladas por el maestro oxoniense del siglo XIII (aunque acotadas seguidamente: "et nunquam cadit ens, secundum quod ens, in sensum, sed in quantum est sub aliquo accidente sensibili, ut calore et albedine, et consimilibus", Blund, Tractatus de anima, 23), quien de cualquier modo remarca la unidad epistemológica de la experiencia y la validez fundamental del conocimiento de los entes a partir de los sentidos.

23. Conforme a la división latina "aviceniana" "in quinque sensus interiores", con el sensus communis y la imaginatio en el ventrículo frontal, la fantasia y la estimativa en el medio y la memoria en el posterior (I, XXIII): Ludovicus de Prussia, Trilogium anime non solum religiosis verum etiam secularibus predicatoribus confessoribus contemplantibus et studentibus lumen intellectus et ardorem affectus amministrans (Núremberg: Antonius Koberger, I498), h. sig. $\mathrm{D}_{4} \mathrm{v}-\mathrm{E}_{\mathrm{I}} \mathrm{r}$.

24. Tres ventrículos aparecen también en Codex Windsor, RL [Royal Library] I26ozr [ca. I 490] (fig. 2). Véase O'Malley y Saunders, Leonardo on the Human Body, 330-33 I, \$ I 42. 25. O’Malley y Saunders, Leonardo on the Human Body, 364-365, \$ I59; Leonardo da Vinci. Anatomical Drawings from the Royal Library, Windsor Castle (Nueva York: The Metropolitan Museum of Art, I983), 44-45. Vid. Martin Kemp, “Il Concetto dell'Anima' in Leonardo's Early Skull Studies", Journal of the Warburg and the Courtauld Institutes 34 (I97I): II9; y Pardo, "Memory, Imagination, Figuration", en Leonard's Writings, ed. Farago, I32.

26. Acaso sólo equiparable al muy próximo esquema de Colonna que ubica a "Cinosia" en la porción frontal, si es que cabe en verdad ver en ella (interpretaciones discutibles) a la dianoética o incluso al "intelecto activo", según sendas propuestas del editor Gabriele y de Semler: Francesco Colonna, Hypnerotomachia Poliphili. Riproduzione dell'edizione aldina del 1499 [Venecia: In aedibus Aldi Manutii, I499], eds. Marco Ariani y Mino Gabriele, 


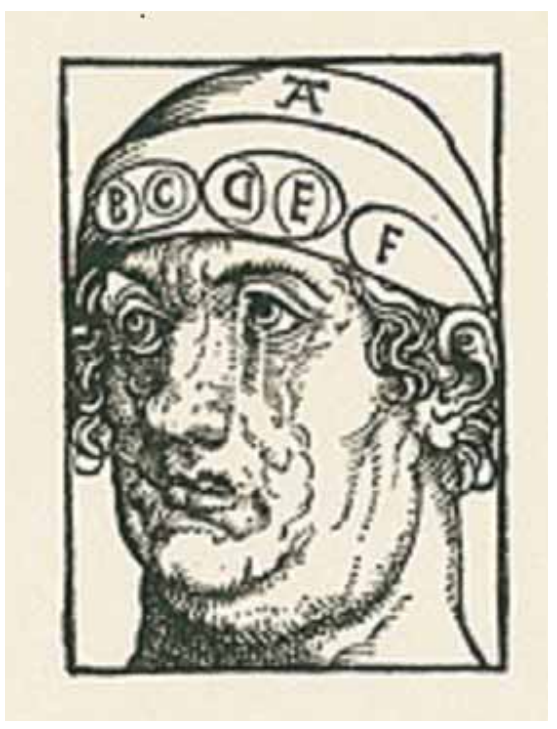

I. Albrecht Dürer, Caput phisicum (posible criptorretrato de Willibald Pirckheimer), grabado en madera. Tomado de Hollstein's German engravings, etchings and woodcuts I400-I700, vol. 7 (Ámsterdam: A. L. van Gendt, I962), 205.

podía confundírsele con el logistikón (situado en el medio), pero que más bien era concebido como carente de localización física (del mismo modo que la voluntas); es posible que con ello pretendiese destacar la primacía de la vista al señalarlo directamente vinculado con ella. Igualmente contradictor respecto de la más vasta tradición psico-fisiológica precedente es la ubicación del sensus communis en el ventrículo medio. Asimismo, en otro esquema contemporáneo (Codex Windsor, RL I2627r) se distinguen (bajo luz ultravioleta) tres facultades: memoria, chomune senso e imprensiva, que corresponden a los ventrículos posterior, medio y anterior. ${ }^{27}$ Esas tres potencias básicas de la clasificación leonardesca (i.e. impressiva, senso comune, memoria) se mantienen, si bien con una disposición más compleja y menos definida (la primera en un doble ventrículo superior que se extiende ampliamente por encima del medio, que acoge la segunda, y del que se desprende el último donde se ubica la tercera) en un dibujo a pluma de un estadio más maduro de sus investigaciones anatómicas

vol. I (Milán: Adelphi, 2004), h. sig. f iii r-v [93] y II, 695-697, n. 6 y L. E. Semler, "Robert Dallington's Hypnerotomachia and the Protestant Antiquity of Elizabethan England", Studies in Philology 103, núm. 2 (2006): 218.

27. O'Malley y Saunders, Leonardo on the Human Body, 366-367, \$ I60; Leonardo da Vinci. Anatomical Drawings, 44-45. 


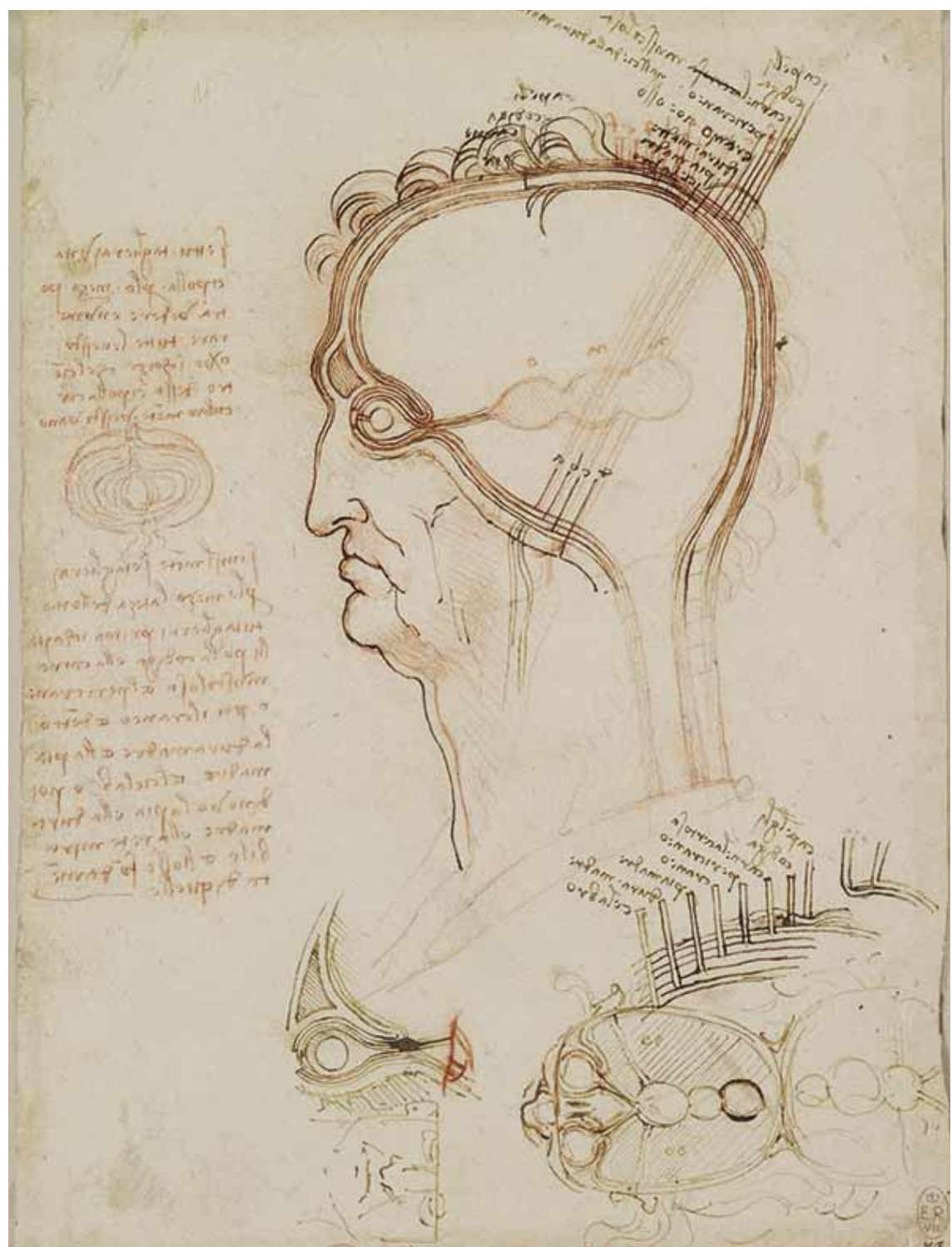

2. Leonardo da Vinci, Ventrículos del cerebro, pluma y tinta y tiza roja, ca. I490. Windsor Castle, RL I2603r. Tomada de la Royal Collection Trust/@ Her Majesty Queen Elizabeth II, 20I3. 
46 SIGMUND MÉNDEZ

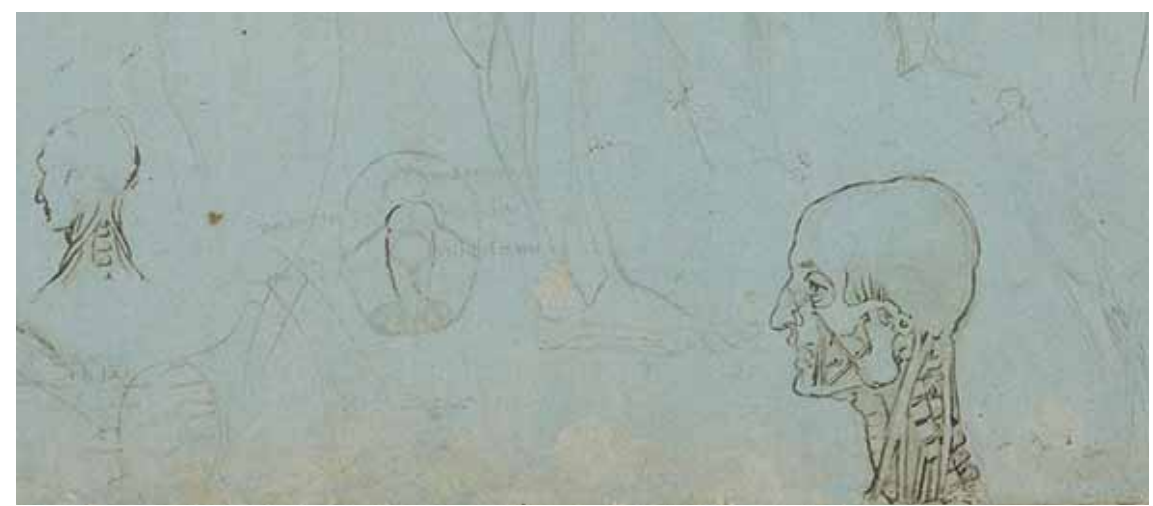

3. Leonardo da Vinci, Cabeza, punta de metal (desvanecido) y pluma y tinta, $c a$. I487-I 489, detalle. Windsor Castle, RL I2626r. Tomada de la Royal Collection Trust/@ Her Majesty Queen Elizabeth II, 2013.

(Weimar, Schlossmuseum, KK 6287; ${ }^{28}$ ca. I506-I508) (fig. 4) y que empata con la representación de los importantes experimentos de inyección de cera de fecha cercana (Windsor Castle, RL I9I 27r, ca. I508-I509) (fig. 5). ${ }^{29}$

Tal división tripartita parece corresponder a la clásica disposición "galénica”, phantastikón, dianoetikón, mnemoneutikón, o imaginatio, cogitatio, memoria; pero, con excepción del nombre y el lugar de la última potencia, sus contrapartes leonardescas resultan singulares y testimonian el modo múltiple de su observancia/independencia intelectual frente a las auctoritates (en otro apunte, consigna asimismo la clasificación platónica). ${ }^{30}$ Pues ese notable

28. Pardo, "Memory, Imagination, Figuration", en Leonard's Writings, ed. Farago, I35I37. Pardo recuerda con justeza la conocida terribilità de estos dibujos maduros a los que corresponde el ejemplo de Weimar.

29. O'Malley y Saunders, Leonardo on the Human Body, 340-34I, \$ I 47; Leonardo da Vinci. Anatomical Drawings, 54-55.

30. "Quattro sono le potenzie: memoria e intelletto, lascibili e concupiscibili. Le due prime son ragionevoli e l'altre sensuali”. Ms. Trivulziano [Milán: Biblioteca del Castello Sforzesco], 7v, en Da Vinci, Scritti scelti, 77 [ca. I487-I490], y The Literary Works, ed. Richter, $\$ 840$. Se trata de la célebre distinción de Platón de dos almas, la divina e inteligible, y la mortal, dividida en una parte irascible y otra concupiscible (véase Timaeus 69c-73d, Respublica 440e8-44Ia3, Phaedrus 253d-e [en Opera, ed. I. Burnet], Aristóteles, De anima III, 9, 432a25-26). Leonardo tamiza estas distinciones asumiéndolas como "potencias" y dividendo de modo ańadido lo que toca al alma inteligible en "intelecto" y "memoria". 
REFLEXIONES TEÓRICAS DE LEONARDO DA VINCI...

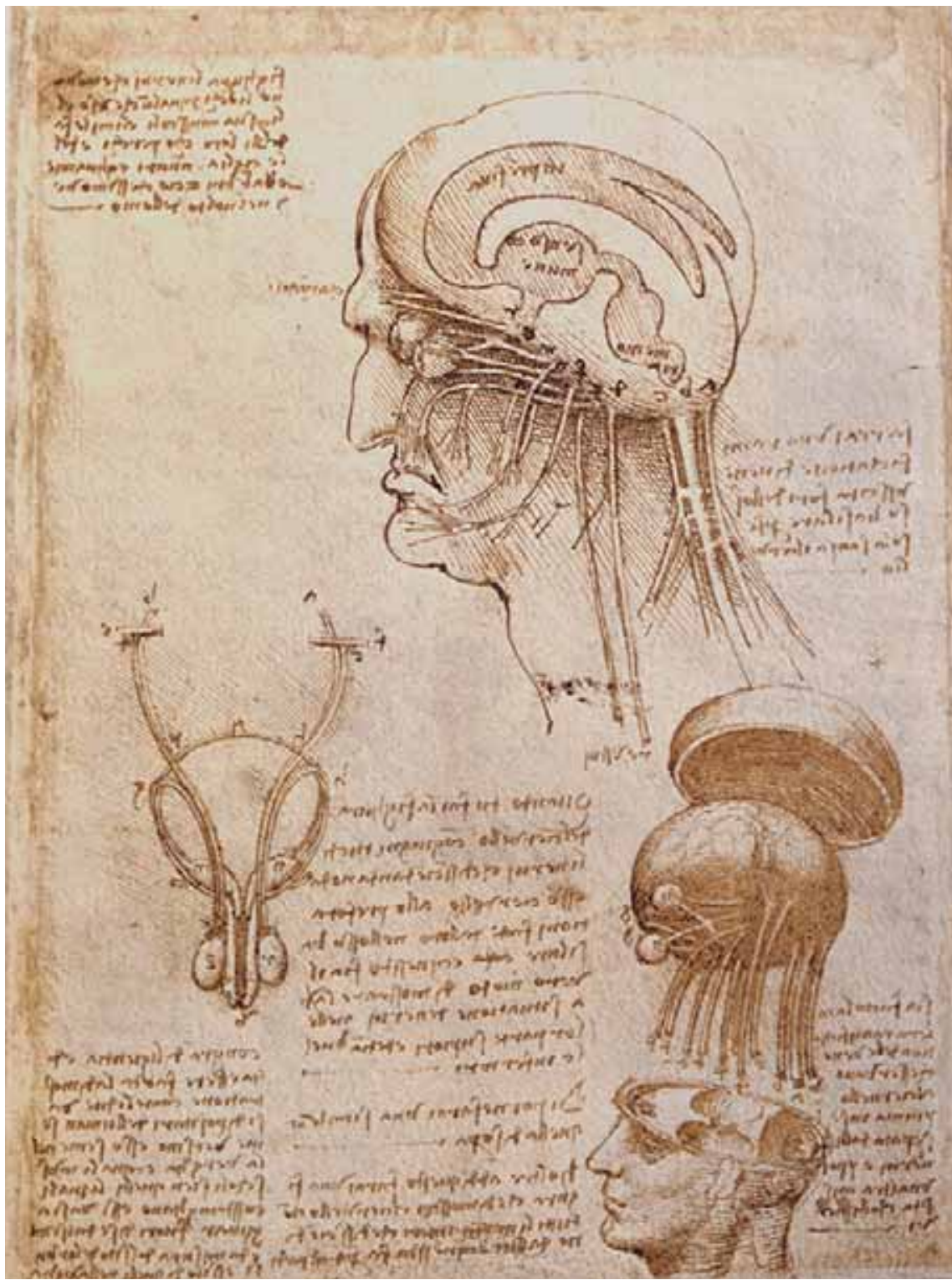

4. Leonardo da Vinci, Estudios anatómicos, pluma y tinta, ca. I506-I508. Weimar, Schlossmuseum, KK 6287. Klassik Stiftung Weimar: Herzogin Anna Amalia Bibliothek. 


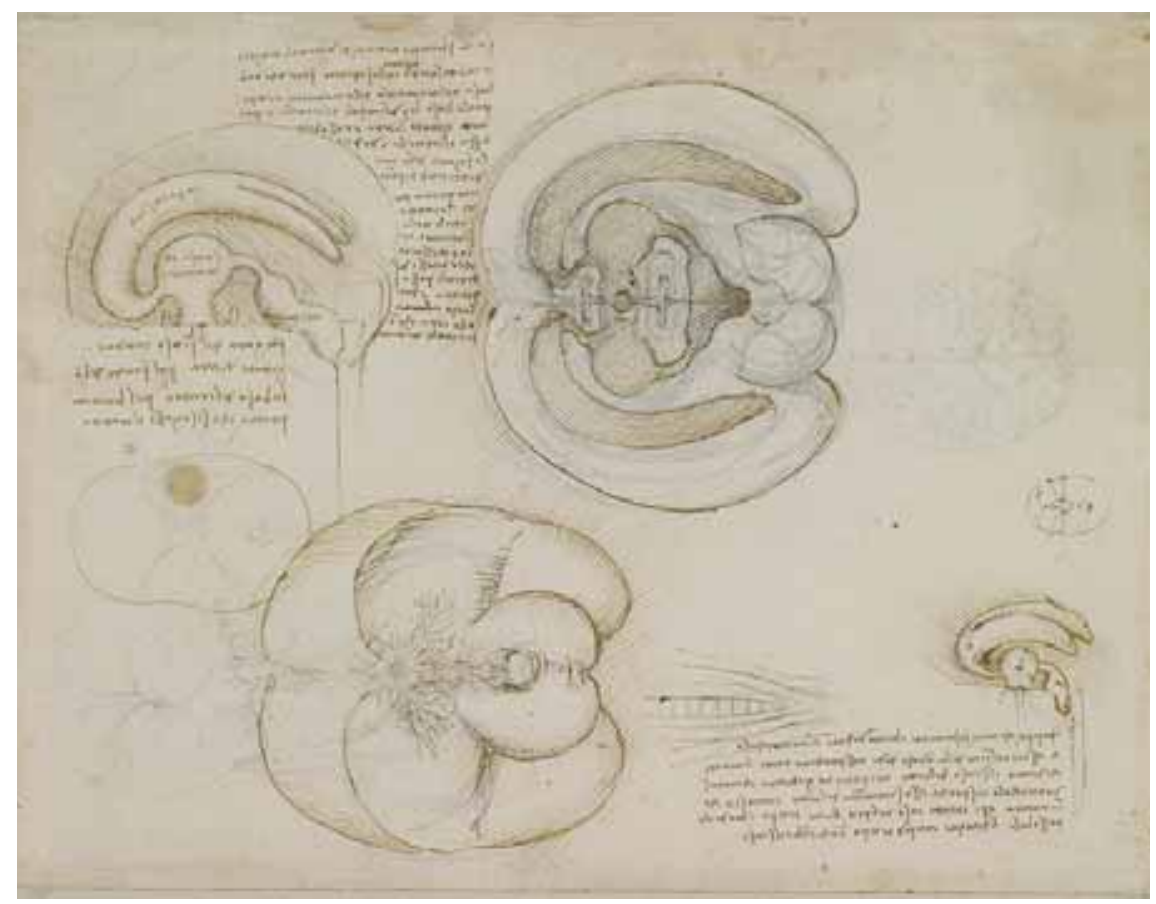

5. Leonardo da Vinci, El cerebro, pluma y tinta sobre tiza negra, ca. I508-I509. Windsor Castle, RL i9I27r. Tomada de la Royal Collection Trust/@ Her Majesty Queen Elizabeth II, 2013.

investigador que fue Leonardo (quien, ilustrado con el "redescubierto" Galeno, se esforzó por "dar luz verdadera a la anatomía"31 como afirmó Vasari), pittore notomista ${ }^{32}$ igualado por Cardano con el propio Vesalio ${ }^{33}$ y cuyo conocimiento del cerebro ha sido a veces reputado en algunos aspectos incluso

31. Giorgio Vasari, Le Vite de' piú eccellenti pittori, scultori ed architettori, ed. Gaetano Milanesi, vol. 4 (Florencia: G. C. Sansoni, I879), 35.

32. Da Vinci, Libro di Pittura, $\$$ I25, 199 [ca. I5I3-I5I4].

33. Al hablar, con argumentos leonardescos, sobre el saber del pintor: "nam pictorem omnia necesse est scire, quoniam omnia imitatur. Est philosophus pictor, architectus, \& dissectionis artifex. Argumento est præclara illa totius humani corporis imitatio, iam pluribus ante annis inchoata a Leonardo Vincio Florentino, \& pene absoluta: sed deerat operi tantus artifex, ac rerum naturæ indagator, quantus est Vesalius". Girolamo Cardano, De subtilitate libri XXI (Lyon: Apud Stephanum Michaelem, I580), 573-574. 
superior al de éste, ${ }^{34}$ respondía aún a la actitud "especulativa” respecto de las "potencias interiores" en un cerebro "fantástico", modelado a la manera de Prometeo — según la ironía de Vesalio— en la explicación de sus funciones orgánicas específicas.

Hay otras referencias sobre estos mismos temas en distintos apuntes: el "sentido común sirve al alma"; así como el músculo obedece al corazón, "el corazón al sentido común, y el sentido común es sede del alma, y la memoria es su consejo, y la impresiva su relatora". ${ }^{35}$ La impressiva sirve de "referendaria" y la memoria da su "advertimiento" 36 al senso comune, en el cual se encuentra la "sede del alma" (a través de un modelo militar-áulico, ${ }^{37}$ del regente asistido por "secretario" y "consejero"); ${ }^{38}$ esta principalía trató incluso de ser reflejada

34. Véase Erwin Panofsky, "Artist, Scientist, Genius: Notes on the 'RenaissanceDämmerung", en Leonard's Writings, ed. Farago, 55, n. 34; Panofsky refiere a M. Holl, "Vesals Anatomie des Gehirns", Archiv für Anatomie und Physiologie, Anatomische Abteilung 39 (I9I5): II5.

35. "la corda al senso comune, e 'l senso comune è sedia dell'anima, e la memoria è sua ammunizione, e la imprensiva è sua referendaria”. Da Vinci, Codex Windsor, RL i9or9, en Da Vinci, Scritti scelti, I55-I56, y The Literary Works, ed. Richter, $\$ 838$.

36. Aunque Richter leía "munición”: “e la memoria è sua munitione”. The Literary Works, $\$ 838$.

37. Que es tópico respecto de una visión jerarquizada de la sociedad y el hombre, ambos entrelazados en la alegoría política del "cuerpo del Estado". Así Gracián calificará a la cabeza como "alcaçar del alma, corte de sus potencias" (I, IX). Baltasar Gracián, El Criticón, ed. Miguel Romera Navarro, vol. I (Filadelfia: University of Pennsylvania, I938), 267.

38. Kemp (“Il Concetto dell'Anima”, I28-I29) entiende esta localización corporal específica de la "sede del alma" como una expresión de una postura antiaristotélica y antiaverroística del intelecto diseminado a través del cuerpo (Codex Windsor, RL i9019 y Da Vinci, Scritti scelti, I55), e interpretable entonces como "neoplatónica" respecto de la idea del alma como cautiva de la prisión corpórea (Da Vinci, Libro di Pittura, $\$$ 28, I52: "Questo è finestra de l'uman corpo, per la quale la sua via specula, e fruisce la bellezza del mondo; per questo l'anima si contenta della umana carcere"), a pesar de que Leonardo considerara de modo contrario que los sentidos (la vista en este caso), en vez de testimoniar su confinamiento, le regalan una satisfacción sucedánea. De cierto Platón enseñó que "la semilla divina” del "alma intelectiva” está ubicada en el cerebro (Timaeus 73c-d; ed. I. Burnet); sin embargo, nótese que Plotino entendió en un sentido activo y no locativo la presencia de la potencia anímica en un órgano del cuerpo, siendo propiamente irreductible a lo corporal (Enneades IV, 3, 2I-22; eds. P. Henry y H. R. Schwyzer [Óxford: Clarendon, I964]); por tanto la razón (lógos), según "los antiguos" (Platón: Timaeus 90a5; en Opera, ed. I. Burnet), se ubica "en las alturas de todo el animal encima de la cabeza, no estando en el cerebro" (Enneades IV, 3, 23, 25-26). Concepciones que, muy probablemente, hubieran resultado poco satisfactorias para Leonardo, quien se encuentra en este caso más próximo a la actitud "empírica” representada por los médicos, 
en los tempranos estudios del cráneo a través de su localización puntual en el cerebro y en simétrica relación con los sentidos con base en una concepción "arquitectónica" del cuerpo (figs. 6 y 7). ${ }^{39}$ Según otro texto, que ratifica lo

ya el propio Galeno (e. g. De locis affectis libri VI, I74-I75; en Opera, vol. VIII, ed. C. G. Kühn [Leipzig: Knobloch, I824]), o, a finales del siglo xv (el pequeńo tratado apareció en Venecia en 1497), Alessandro Benedetti (cuya opinión se expresa adjuntada con elementos teo-antropológicos de prosapia platónica y cristiana): "Collum caput sustinet, in quo cerebrum viscerum excellentissimum continetur cælo proximum. Hinc euidentius intellectus culmen altissimum habet, $\&$ humana ratio, quam effector mundi, molitorque deus per filium maxime sibi proximam fecit" (III, II). Alessandro Benedetti, Anatomice siue historia corporis humani (París: in officina Henrici Stephani, I5I4), 3IV-32r. O bien, posteriormente, por un Fracastoro, quien tendió a dejar de lado la teoría "supracorporal" del intellectus agens y desprendido por entero de la phantasía y el sensus communis, para enfocarse en una solución más física (adecuada a este médico-poeta precursor de la epidemiología), y hablar así de una "particula cognoscitiva", afectada de modo diverso por los humores (la superior inteligencia es seca y caliente, aunque mejor si de modo "moderado", la flema excesiva produce una pinguis Minerva, etcétera), ubicando - pese a las vacilaciones al respecto - al intellectus en el segundo ventrículo. Véase Girolamo Fracastoro, Turrius siue de intellectione II [III], en Opera omnia (Venecia: Apud Iuntas, I555), 202r-205r. Tanto Benedetti como el propio Fracastoro, en diversos modos, parecen deudores de la exposición más material de las funciones del cerebro conocida por la Edad Media, expuesta por Constabulus (Costa ben Luca).

39. Codex Windsor, RL 19057r y I9058r. O'Malley y Saunders, Leonardo on the Human Body, 50-53, \$6 y 7; véase Kemp, “Il Concetto dell'Anima”, ir 8. La posición correlativa del corazón y la parte central del cerebro es algo asumido por la teoría anatómica medieval y renacentista; así lo muestra Mondino de' Liuzzi en su Anathomia, sobre la cogitativa en el ventrículo medio: "Item quia ipsa est virtus regitiua totius animalis. regimem autem totius animalis consistit in apprehensione presentium: memoria preteritorum: pronosticatione futurorum \& ideo debuit esse in medio harum virtutum apprehensiuarum et memoratiuarum: fuit etiam in medio horum ventriculorum vt sit virtus eius in directo ad cor". Mondino de' Liuzzi, Anothomia Mondini nuper optime emendata ac summa diligentia impressa (Venecia: per presbyterum Bonetum Locatellum Bergomensem, I507), IOv a. O bien, Benedetti (hablando, en este caso, del vermis): "Ob id, ea via cordi veluti omnium principio supra constituta est" (IV, XII). Benedetti, Anatomice, 43r. Piénsese también en la conciliación propuesta por un Kilwardby (De spiritu fantastico, I08-130; qu. 4: "Quod menbrum corporis sit organum sensus communis", I08-I30) entre la postura de teólogos y médicos y la de Aristóteles, implicando la participación conjunta de cerebrum y cor en las operaciones del sensus communis y la phantasía. Todavía Descartes considera esta relación orgánica y estructural entre cerebro y corazón en la teoría de los espíritus animales y los procesos propios del sensus communis, la imaginatio y la memoria (La Description du corps humain, I, viI): "Et enfin les parties de ce sang les plus agitées \& les plus viues, estant portées au cerueau par les arteres qui viennent du cœur le plus en ligne droite de toutes, composent comme vn air, ou vn vent tres subtil, qu'on nomme les Esprits animaux; lesquels, dilatans le cerueau, le rendent propre à receuoir les impressions 
REFLEXIONES TEÓRICAS DE LEONARDO DA VINCI...

6. Leonardo da Vinci, El cráneo seccionado, pluma y tinta sobre tiza negra, $c a$. I489. Windsor Castle, RL i9057r. Tomada de la Royal Collection Trust/C Her Majesty Queen Elizabeth II, 20I3.

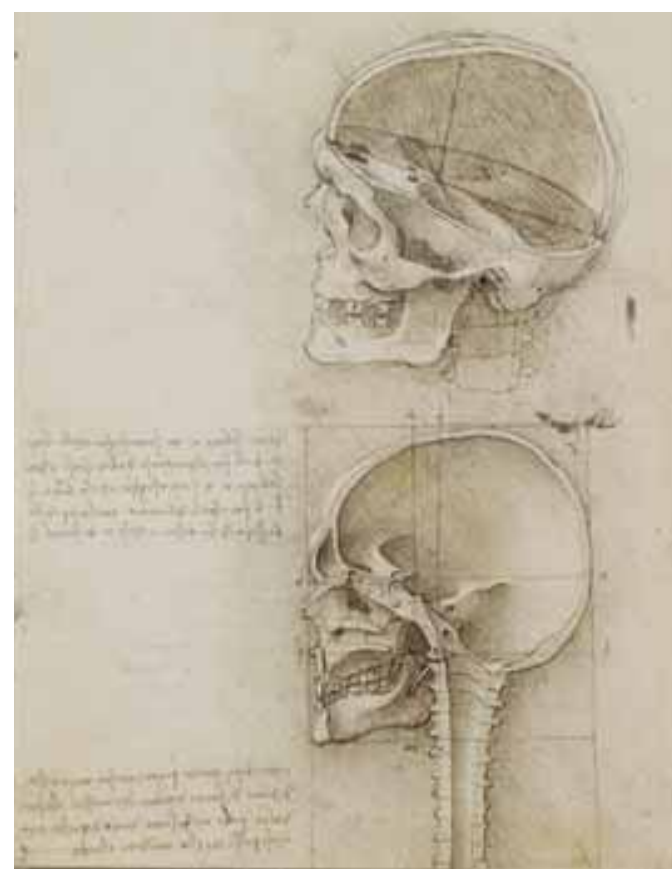

presentado en el esquema de las potencias en el temprano apunte del Codex Windsor (RL I2626r), ${ }^{\circ}$ la pupila, que es por sí misma "de naturaleza aprehensiva", está directamente conectada con la primera virtus: "Y este mismo círculo tiene en sí un punto, que parece negro, el cual es un nervio perforado que va hacia dentro a la potencia intrínseca, mismo que está lleno de la virtud impresiva y de juicio, que pasa al sentido común". ${ }^{4 \mathrm{I}}$ De este modo, habría un spiritus impressivus ${ }^{42}$ que va del ojo a la facultad que lo rige - la cual tie-

des objets exterieurs, \& aussi celles de l'ame, c'est à dire, à estre l'organe, ou le siege, du Sens commun, de l'Imagination, \& de la Memoire". Réne Descartes, CEuvres de Descartes, eds. Charles Adam y Paul Tannery, vol. in (París: J. Vrin, I996), 227.

40. O'Malley y Saunders, Leonardo on the Human Body, 364-365, \$159.

4I. "E questo circulo medesimo ha in sè uno punto, che apparisce nero, il quale è uno nervo forato, che va dentro alle intrinsiche virtù, il quale è pieno della virtù imprensiva e giudiziale, che capita al comun senso". Da Vinci, Codex Atlanticus, 27or b, en Da Vinci, Scritti scelti, $\mathrm{I} 66$.

42. La expresión, por cierto, la usará Zuccaro, aplicada al disegno como Idea: "poiche è 


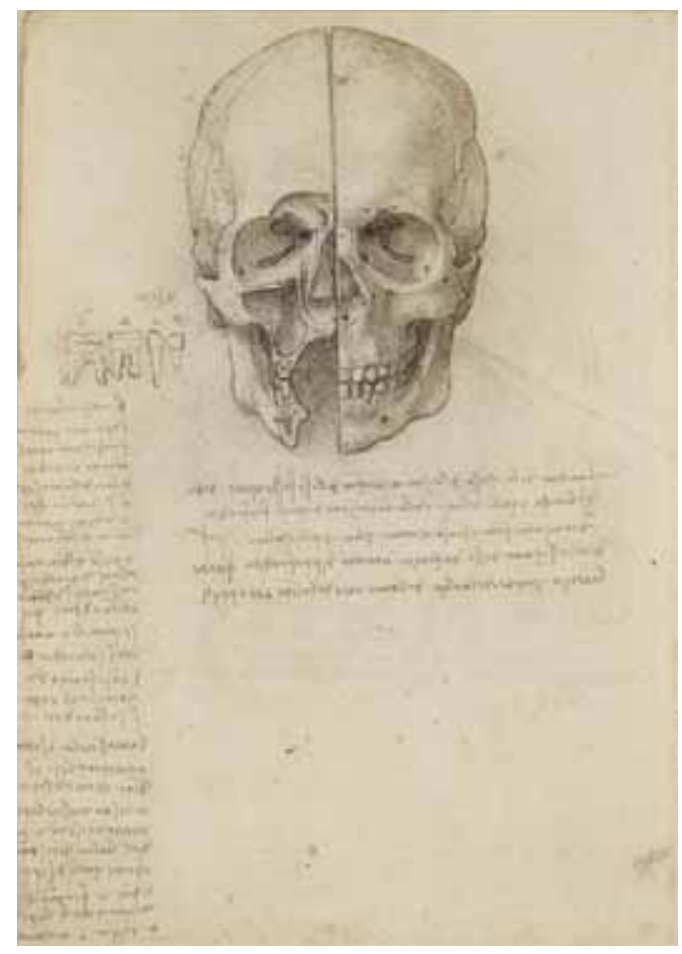

7. Leonardo da Vinci, El cráneo seccionado, pluma y tinta, $c a$. I489. Windsor Castle, RL i9058r. Tomada de la Royal Collection Trust/@ Her Majesty Queen Elizabeth II, 20I3.

ne en efecto una cavidad propia, el ventriculo della imprensiva - vinculado estrechamente con la capacidad misma de ver (la visión nocturna de ciertos animales respecto del hombre radica en la diferente proporción de la pupila y el lugar interior de esta facultad); 43 el ojo participa por ello también de la po-

Idea, spirito impressiuo, e formatiuo di tutte le cose in noi". Federico Zuccaro, L'Idea de' pittori, scultori, et architetti, facsímil de la ed. Torino: Agostino Disserolio, I607, lib. I, 36, ed. por Detlef Heikamp, en Scritti d'arte (Florencia: Leo S. Olschki, I96r), I84. En este caso, sin embargo, se refiere a un principio anímico, cuyo valor "activo" corresponde a su uso en Giordano Bruno: "in principio activo seu impressivo". Libri physicorum Aristotelis explanati III, en Giordano Bruno, Opera Latine conscripta, eds. F. Tocco y H. Vitelli, vol. 3 (Florencia: Typis Successorum Le Monnier, I89I), 335.

43. Da Vinci, Codex D [París: Institut de France, Ms. D (2175)], 5v-r, en Da Vinci, Scritti scelti, 400; en el búho la pupila (fuente de la luz) es mucho mayor que la imprensiva, a diferencia del hombre: "E questa imprensiva dell'omo rispetto a quella del cufo è come una gran sala che ha lume per una piccola busa, rispetto a una piccola sala tutta aperta: che nella gran 
tencia impresiva y de juicio — cada sentido, en efecto, “juzga”, krinei, lo que le compete: De anima III, 2, 426b8-I I - de modo parcial —lo que explica el giudizio dell'occhio_, aunque dichas operaciones pertenezcan cabalmente a las sedes cerebrales correspondientes.

A este propósito, bien pudo Leonardo aprovechar las consideraciones de los teóricos medievales sobre la perspectiva, como la de Alhacén acerca del "sintiente último" (ultimum sentiens), ${ }^{44}$ identificable, como explicaba Roger Bacon, con el sensus communis pero, en sentido estricto, referido a la unidad interior de los órganos sensoriales particulares, como en el "nervio co-

sala v'è notte di mezzogiorno, e nella piccola aperta v'è giorno di mezzanotte, non essendo il tempo nuvoloso". Nótese de modo añadido este apunte del Codex Arundel [Londres: British Museum], I7IV.[I506-I508]: "Neciessaria cosa sarebbe se la inprensiva fussi fori del'ochio che le linee rette non avessino loco. Inperochè benchè $b$ venga per linea retta all'ochio $f$, e da $f$ vada in $d$, non di meno la linea che va alla inprensiva sia nel'ochio; el nervo che si parte da l'ochio e va al cielabro, è simile alle corde perforate che con infinite rami tessano la pella de' corpi, e per lor vacui si porta al comune sens", en James S. Ackerman, "Leonardo's Eye", Journal of the Warburg and the Courtauld Institutes 4I (I978): I40. La versión de Ackerman redunda en un énfasis excesivo: "la linea che va alla inprensiva sia nel'ochio" por "it is necessary that the imprensiva be in the eye". De manera singular, Summers ha concluido que la imprensiva corresponde a "one of the surfaces of the eye". David Summers, The Judgment of Sense: Renaissance Naturalism and the Rise of Aesthetics (Cambridge: Cambridge University Press, 1987), 7I. Sin embargo, aunque en el texto del Codex Arundel no sea tal cosa explícita, puede conjeturarse que el parecer de Leonardo es consistente con lo vertido en el precitado apunte contemporáneo del Codex $D$, $5 \mathrm{v}$-r: el nervio que comunica al ojo con la imprensiva esta impregnado con su "espíritu" para hacer posible la visión, pero la facultad en sí misma tiene un locus propio dentro del cerebro.

44. "Deinde iste sensus qui cadit apud glacialem extenditur in nervo obtico et venit ad anterius cerebri, et illic est ultimus sensus et sentiens ultimum quod est virtus sensitiva que est in anteriori cerebri, et ista virtus comprehendet sensibilia. Visus autem non est nisi quoddam instrumentum istius virtutis, quoniam visus recipit formas rerum visarum et redit eas sentienti ultimo, et sentiens ultimum comprehendit illas formas et comprehendit ex eis res visibiles que sunt in eis. Et illa forma in superficie glacialis extenditur in corpore glacialis, deinde in corpus subtile quod est in concavo nervi quousque perveniat ad nervum communem. Et apud perventum forme ad nervum communem completur visio, et ex forma perveniente in nervo communi comprehendet ultimum sentiens formas rerum visarum." Alhacén, De aspectibus I, 6, 68, 13-26, en Alhacen's Theory of Visual Perception. A Critical Edition, with English Translation and Commentary, of the First Three Books of Alhacen's "De aspectibus", the Medieval Latin Version of Ibn al-Haytham's "Kitāb al-Manā ir", ed. A. Mark Smith, vols. I y 2 Transactions of the American Philosophical Society 9I, 4-5 (Filadelfia: American Philosophical Society, 200I), 52. 
mún” de los ojos 45 (virtus visiva fontalis); del "juicio" sobre las cosas visibles se entiende que son también partícipes los ojos, de modo parcial, completándose en el ultimum sentiens; ${ }^{46}$ en este ámbito, el sensus communis tendría que verse como el ejecutor pleno del iudicium de la cosa en la integridad de su manifestación: "el sentido común es aquel que juzga las cosas a él dadas de los otros sentidos"47 (aunque Bacon atribuyó cabalmente a la phantasía dicho acto: "el juicio completo del objeto, que ejerce la fantasía"). ${ }^{48}$ Leonardo parece desarrollar estas nociones, ubicando lo propio al "nervio común" en una cavidad cerebral particular que corresponde a la impressiva, deslindada del sensus communis al que tradicionalmente se le atribuye la inmediata percepción interior que, a cambio, ocupa la posición media del cerebro como gran

45. "Quoniam autem Alhacen dicit quod istud ultimum sentiens est in anteriori parte cerebri, videretur sic alicui quod esset sensus communis et ymaginatio vel fantasia, que sunt in anteriori cerebro, ut prius dictum est, percipue cum ibi dictum sit quod non completar iudicium de aliquo sensibili antequam veniat species ad sensum communem. Sed dicendum est quod ultimum sentients potest esse origo omnium sensuum; et sic non loquitur hic de ultimo sentiente, hoc enim est sensus communis in anteriori cerebri. Aliter est ultimum sentiens specialiter in visu vel auditu vel odoratu vel aliis, loquendo de uno sensu particulari. Et sic ultimum sentiens est nervus communis in visu respectu duorum oculorum, qui sunt instrumenta que prima immutantur a visibili" (I, 5, 3, 94-I05). Roger Bacon, Perspectiva, en Roger Bacon and the Origins of "Perspectiva" in the Middle Ages, ed. David C. Lindberg (Óxford: Clarendon Press, I996), 64 y 66. Véase Lorenzo Ghiberti, I commentarii (III, XI, 3), ed. Lorenzo Bartoli (Florencia: Giunti, I998), I42.

46. "Et sic patet quod non solum oculi iudicant de visibili; sed incipitur iudicium in eis, et completur per ultimum sentiens, quod est virtus visiva fontalis in nervo communi [...] Et licet dicat quod oculus est instrumentum ultimi sentientis et medium inter ipsum et visibile, tamen oculus necessario habet iudicium et virtutem videndi, licet incompletum" (I, 5, 3, I20I22 y I27-I30). Bacon, Perspectiva, 66. Véase Ghiberti, I commentarii, I 43.

47. "Il senso comune è quello che giudica le cose a lui date da li altri sensi". Da Vinci, Codex Atlanticus, $90 \mathrm{r}$ b, en Da Vinci, Scritti scelti, I57; y The Literary Works, ed. Richter, $\$ 836$. Recuérdese que, según Aristóteles, cada sentido juzga lo propio, como la facultad sensitiva general capaz de juzgar (krinein) también los distintos sensibles, de modo que "entiende y percibe" (De anima III, 2, 426b22). En el pequeño tratado de Alessandro Benedetti se señala "sensus namque communis de exterioribus iudicium affert" (IV, x). Benedetti, Anatomice, 42v. Por su parte, Lorenzo de' Medici, refiriéndose al juicio de la forma aprehendida por la vista: "Questa tale forma così veduta, dalla cristallina si transferisce al senso comune, che giudica per questo le qualità di quella tale cosa”. Lorenzo de' Medici, Comento de' miei sonetti, "Nuovo argumento" XVII, I8, en Tutte le opere, ed. Paolo Orvieto, vol. I (Roma: Salerno, I992), 444.

48. "iudicium completum de re, quod exercet fantasia" (I, I, 2, I09). Bacon, Perspectiva, 8. 
centro comprensor. Ello indica la posición analítica de Leonardo respecto del conocimiento sensible en su fase inicial —a mitad de lo ocular y lo psicológico-,${ }^{49}$ en el que cada sentido es procesado de forma individual antes de su integración y juicio en la potencia central del alma.

Finalmente, es oportuno citar una explicación general de la cognición a partir de los sentidos:

Y este nombre de sentido común usan solamente porque es juez común de los otros cinco sentidos, es decir: ver, oír, tocar, gustar y oler. El sentido común se mueve mediante la impresiva que está colocada en medio entre él y los sentidos. La impresiva se mueve mediante las semejanzas de las cosas a ella dadas de los otros órganos superficiales, es decir los sentidos, los cuales están colocados en medio entre las cosas exteriores y la impresiva; y de modo similar los sentidos se mueven mediante los objetos. Las semejanzas de las cosas circunstantes mandan sus semejanzas a los sentidos, y los sentidos las transfieren a la impresiva, la impresiva las manda al sentido común, y por él son establecidas en la memoria, y allí son más o menos retenidas, según la importancia o fuerza de la cosa dada. Aquel sentido que es más próximo a la impresiva es más veloz en su oficio: el ojo. ${ }^{50}$

De manera muy general, los procesos aquí descritos corresponden a una exposición tópica del paso del conocimiento de los fenómenos desde una instancia receptora a otra central comprensora y, finalmente, a una retentiva. Hacer, sin embargo, del sensus communis, la parte iudiziale que es sede del alma y la fa-

49. De acuerdo con Ackerman, "Leonardo's Eye", I4I: "the theory of the imprensiva was an effort to explain functions that we now attribute partly to the retina and partly to the psychology of perception, the workings of which are still not entirely clear".

50. "E questo nome di senso comune dicano solamente perchè è comune iudice de li altri 5 sensi, cioè: vedere, uldire, toccare, gustare e odorare. Il senso comune si move mediante la imprensiva ch'è posta in mezzo infra lui e i sensi. La imprensiva si move mediante le similitudine delle cose a lei date da li strumenti superfiziali, cioè sensi, i quali sono posti in mezzo infra le cose isteriori e la imprensiva; e similemente i sensi si movano mediante li obbietti. Le similitudine delle circunstanti cose mandano le loro similitudine a' sensi, e sensi le transferiscano alla imprensiva, la imprensiva le manda al senso comune, e da quello sono stabilite nella memoria, e lì sono più o meno retenute, secondo la importanzia o potenzia della cosa data. Quello senso è più veloce nel suo uffizio, il quale è più visino alla imprensiva: è l'occhio [...]". Da Vinci, Codex Atlanticus, 9or b, en Da Vinci, Scritti scelti, I58; y The Literary Works, ed. Richter, $\$ 836$. 
cultad principal (que parece subsumir la "razón particular" de la cogitativa), , I prácticamente el hegemonikón o potencia rectora general,,$^{52}$ es de cierto una "anomalía" que pone a la vista esa tendencia de proponer a los sentidos, y en especial, el de la vista, como estructura cognoscitiva primaria del hombre; aunque puedan evocarse a este propósito las lecciones estoicas del hegemonikón como "el primer sensitivo" (tò prôton aisthetikón, Galeno, De symptomatum causis I, 8; ed. Kühn, vol. VII, I39= Stoicorum Veterum Fragmenta II, 855, 23I, 7, ed. von Arnim). También es de notar que el sensus mismo como imago in praesentia, e incluso entendido como "juicio de lo particular" y no de lo universal, 53 corresponde a la postura epistemológica leonardesca y su énfasis sobre la presencialidad visual e interesada más, en todo caso, en los particularia que en las leyes universales ${ }^{54}$ (lo que sugiere también su vínculo con la

5I. A la que posicionalmente sustituye. Sobre ella, valga citar lo que señalará Varchi: "La ragione particolare è intorno alle intenzioni individuali, come dicono essi, cioè non conosce e non intende se non le cose particolari, e conseguentemente generabili e corrutibili; e questa fu chiamata da Aristotile, secondo che testimonia il suo grandissimo Comentatore [i.e. Averroes], cogitativa; la quale, se bene è mortale, non si trova però negli animali bruti, i quali hanno in quella vece la stimativa, assai meno perfetta che non è la cogitativa negli uomini”. Benedetto Varchi, "Della maggioranza e nobiltà dell'arti”, en Tratatti d'arte del Cinquecento, ed. Paola Barocchi, vol. I, Scrittori d'Italia 219 (Bari: Gius. Laterza \& Figli, I960), 7. La pintura está volcada, por su propia modalidad representativa, a lo "particular", "generable" y "corruptible", por lo que, en efecto, puede entenderse supeditada a la correspondiente "razón particular" que, en Leonardo, parece ser "devorada” por el sensus communis. Y más aún, al concurrir en la "sede del alma”, esto sugiere el esbozo de una integración de lo sensorial-comprensor que muestra, por otra parte, la forma distintiva de las pretensiones "universales" que el arte despliega en su pensamiento. Esto no desarmoniza con el modus operandi del "desorden" de su despliegue, que entiende dicha "universalidad", no como un conjunto jerárquico de leyes abstractas generales, sino como abarcador conocimiento de los "singulares", es decir, remitido en todo momento a cada fenómeno que se haga "presente a los ojos" en su discurrir por el mundo.

52. Según apunta Summers, The Judgment of Sense, 92 y 98 (pero no debiera entenderse, como pretende el mismo Summers - 73, n. 3-, que el ojo corresponda al sensus communis).

53. Por un lado, según comenta Landino: "È el senso comune quello al quale e sensi exteriori ciò che comprendono riferiscono; et in quanto è senso riceve le imagini delle chose sanza materia; ma solo mentre insino che la materia è presente". Asimismo, como correspondiente a la "ragione inferiore [...] che discorre pe' particulari: 'Questo giudicio [el que evalúa un ente exterior particular como potencialmente bienhechor o dañoso] è proprio del senso, et per questo è non solamente nell'huomo, ma anchora ne gl'altri animali. Ma è sempre nelle chose particulari, perché el senso non può comprendere gl'universali" (Inferno XxIII, I9-30). Cristoforo Landino, Comento sopra la Comedia, ed. Paolo Procaccioli, vol. 2 (Roma: Salerno, 200I), 8I6 y 8I8.

54. Como explicaba santo Tomás: "Nam, cum sensus sit cognitio particularium, intellectus 
phantasía como máxima "cognitio particularium").55 El sensus communis es aquí, verdaderamente, la médula de la empeiría, ${ }^{56}$ y ésta el fundamento de la cognición humana, donde las semejanzas entre percibir con los sentidos y pensar ("pues en estos dos el alma juzga y conoce alguno de los entes": De anima III, 3, 427a2I) parecen de pronto resolverse en una identidad entera.

A pesar de que la phantasíalimaginatio o imaginativa (al igual que la aestimativa y/o la cogitativa) no aparecen en este esquema de las potencias interiores, no puede dejar de conjeturarse su pertenencia a este mismo ámbito si contextualizamos su peculiar orden con relación a distintas enseñanzas sobre este tema desde la Antigüedad. Respecto de la impressiva lapprehensi$v a$ es oportuno recordar el concepto estoico de la phantasía como týposin en psychêe (Diógenes Laercio, Vitae philosophorum VII, 45-46), la "impresión en el alma”, en tanto que acto por el cual algo es impreso (týposis y phantasial týpoma y phántasma); luego, en la Edad Media, la apprehensiva pudo ser contada entre las capacidades propias de la imaginatio. 57 De modo ańadido, está el estrecho vínculo entre el sensus communis y la phantasía, sugerido por las reflexiones de Sinesio de Cirene (cuyo tratado, cabe recordar, fue traducido por Marsilio Ficino), de las que se puede deducir una cierta identidad entre ambos; la potencia fantástica es "ella misma sentido de los sentidos, ya que el pneuma fantástico es la facultad más común y cuerpo primero del alma” ( $D e$ insomniis $\mathrm{V}, \mathrm{I} 35 \mathrm{D}-\mathrm{I} 36$; ed. N. Terzaghi).${ }^{8}$ Es algo no ajeno a las teorías de los

per hoc ab ipso differre videtur, quod universalia comprehendit". Santo Tomás de Aquino, "Proemio", Commento alla "Metafisica" di Aristotele e testo integrale di Aristotele, ed. Lorenzo Perotto, vol. I (Bolonia: Edizioni Studio Domenicano, 2004), 38.

55. Según la indicación de san Alberto Magno, la phantasía es el summum de los sentidos interiores para el conocimiento de las cosas particulares, pues su primer fin "est cognitio particularium major quam in sensibili anima haberi potest" (III, I, III). San Alberto Magno, Liber de anima, en Opera Omnia, ed. Augustus Borgnet, vol. 5 (París: Apud Ludovicum Vivès, I890), 318.

56. Véase la ya mencionada interpretación de Gregoric, Aristotle on the Common Sense, 204207, sobre el "sentido común" en Aristóteles.

57. Así en Robert Kilwardby, Despiritu fantastico (q. 4, 257), i I 5: "Et accipio 'apprehensiuam' communiter pro cognitiua; ideo enim dixi ymaginatiuam esse apprehensiuam"; y Ramon Lull, De ascensu et descensu intellectus V, I0, 75-77; vol. 35 de Corpus Christianorum Continuatio Mediaevalis, ed. Aloisius Madre (Turnhout: Brepols, 198I), 77: "quod imaginatio est forma, habens in se tres potentias, scilicet potentiam apprehensiuam, potentiam appetitiuam et potentiam existimatiuam".

58. "hæc enim sensus est sensuum. quoniam phantasticus ipse spiritus sensorium est communissimum, primumque animæ corpus". Synesius De Somniis translatus a Marsilio Ficino Florentino ad Petrum Medicem, en Ficino, Opera, I970. 
sentidos interiores en la Edad Media, donde varias potencias quedan en este punto coligadas. Una autoridad en la materia, Avicena, es ejemplar respecto de su complejo deslinde:

Una potencia es la que se llama sentido común y fantasía; y en los médicos son de cierto una potencia, pero en los que dan testimonio de los filósofos son dos potencias. El sentido común es aquélla que recibe todas las cosas percibidas por el sentido; y las admite de cerca a sus formas, que en ella son ligadas. La fantasía en verdad es aquella que las guarda después de que son unidas y las conserva tras la ausencia del sentido. Y ya que una de estas dos es la que recibe, la otra es por la que se resguarda. Esto en efecto es lo que pueden certificar los filósofos. Pero sea del modo en que fuere, la sede de ella y el principio de su operación es el ventrículo anterior del cerebro. ${ }^{59}$

En el Liber de anima, del mismo Avicena, aparece una equipolencia total -a la manera "de los médicos" - entre las dos primeras potencias, al grado de trasladar phantasía (ban àsiyā) como equivalente de sensus communis; ${ }^{60}$ ahí se señala también que: "el sentido común, la imaginación y la fantasía son casi una misma potencia". ${ }^{6}$ San Alberto Magno es uno de los difusores de este conocimiento, que incluye la mudable caracterización de tales potencias, mientras que Roger Bacon registra la creencia de que sensus communis e imaginatio se reunían en la célula frontal del cerebro bajo una misma facul-

59. "vna est virtus quæ vocatur sensus communis et phantasia. et apud medicos quidem sunt vna virtus, sed apud certificantes, qui sunt ex philosophis due sunt virtutes. Sensus enim communis est illa quæ omnia sensu percepta recipit. \& ab eorum formis patitur, quæ in ipsa coiunguntur. Phantasia vero, est illa, quæ eas custodit postquam coniunguntur et retinet eas post sensus absentiam. Et quae harum duarum est recipiens, alia est à custodiente. Hoc autem certificare est philosophi. Sed qualitercunque fuerit, eius sedes, \& operationis eius principium est anterior cerebri ventriculus" (Liber I, Fen. I, Doctrina VI, cap. 5). Avicena, Liber Canonis, De medicinis cordialibus, et Cantica, iam olim quidem a Gerardo Carmonensi ex arabico sermone in latinum conuersa (Venecia: en Iuntas, I555), $27 \mathrm{v}$.

6o. Avicena, Liber De Anima I, IV, 20, ed. van Riet, vol. I, 87. Equivalencia repetida por Salutati: "Comprehendit etiam res secundum quod in aliquo determinato loco sunt, quam vim solent appellare philosophi sensum communem. Et non solum hac vi, que etiam fantasia dicitur, queve semper exigit presentiam sensibilem, sed etiam ex imaginatione, que sic retinet percepta per fantasiam aut sensum communem quod sensibilis presentiam non requirat." Coluccio Salutati, De laboribus Herculis (II, XVII), ed. B. L. Ullman, vol. I (Zúrich: Thesaurus Mundi, I95I), I47.

6I. "sensus communis et imaginatio et fantasia sunt quasi una virtus". Avicena, Liber De Anima IV, I, 64-65, ed. van Riet, vol. 2, 5. 
tad llamada phantasía que, en última instancia, comprendía sus operaciones como el todo a sus partes. ${ }^{62}$ Luego Mondino de' Liuzzi, profesor de anatomía en Bolonia a principios del siglo XIV, explicaba su ubicación en los ventrículos frontales (la fantasia adelante, la imaginativa atrás y el sensus communis en medio), consignando la posibilidad de entenderlas todas como una misma facultad. Su discrimen en un contemporáneo de Leonardo y heredero de Mondino, Alessandro Benedetti, no ha evolucionado e incluso se ha desdibujado de modo parcial evidenciando el desgaste de las teorías psicofisiológicas. También en tiempos de Leonardo, Pico (el Joven) apuntó esa vacilante diferenciación entre las potencias señaladas en los numerosos estudios en torno a ellas, añadiendo la memoria ${ }^{63}$ (cuya función retentiva correspondería de modo específico, según la versión latina del Canon y tratándose de sensibilia, a la phantasía, o a la imaginatio según el De anima del mismo Avicena), recordando el dificultoso tema de que tal vez "sea una sola la potencia sensitiva del alma, que, ya el nombre de sentido común, ya de facultad imaginaria, ya de memoria, recibe según la diversidad de sus funciones". ${ }^{4}$ Hacia mediados del siglo XVI, Melanchton adoptará sensus communis como translado de phantasía, prefiriendo, según se deduce de su uso, aquella designación; ${ }^{65}$ y

62. "Et sic est in organo sensus communis et imaginationis. Et tamen tota virtus composita ex his duabus, scilicet, quae occupat totam cellulam primam, vocatur phantasia [...] Quapropter phantasia comprehendit utramque virtutem, et non differt ab eis nisi sicut totum a parte." Roger Bacon, V, I, II, en The "Opus Majus" of Roger Bacon, ed. John Henry Bridges, vol. 2 (Londres/Edimburgo/Óxford: Williams and Norgate, I900), 5. Véase Bacon, Perspectiva, I, I, 2, IOO-IO7, $\$ 8$.

63. Por ejemplo lo señalado por Roger Bacon: "Apud igitur translationem Aristotelis vulgatam, vocatur omnis virtus memoria que habet potestatem retinendi species; et ideo tam archa sensus communis quam estimationis secundum hoc vocatur memoria. Et ideo quod hic vocatur ymaginatio comprehenditur sub memoria apud translationem Aristotelis que est in usu vulgi” (I, I, 5, 267-27I). Bacon, Perspectiva, I8.

64. "sit unica tantum sensualis animae potestas, quae modo sensus communis, modo imaginariae facultatis, modo memoriae nomen pro functionum diversitate obtineat". Gianfrancesco Pico della Mirandola, On the Imagination, ed. Harry Caplan (New Haven/ Londres/Óxford: Yale University/Humphrey Milford/Oxford University/Cornell University, I930), 34 .

65. "Tres sunt sensus interiores, sensus Communis, Cogitatio seu compositio, \& Memoria. Galenus nominat phantastikòn, dianoetikòn, \& mnemoneutikón [...] Nam sensus communis apprehendit imagines oblatas a sensibus exterioribus, \& discernit obiecta singulorum sensuum". Philipp Melanchton, Commentarius De anima (Wittenberg: Ex officina Typographica hæredum Petri Seitzij, I550), i Ior. 
aún Descartes se refiere a lo conocido "con el sentido común, según lo llaman, esto es, la potencia generadora de imágenes" ${ }^{66}$

Estos indicios avalarían como una hipótesis no infundada la de Martin Kemp de suponer que phantasia-imaginatio tendría que estar, en el esquema de las potencias leonardesco, en el segundo ventrículo junto con el sensus communis, ${ }^{67}$ aunque no al grado de confundirse siempre en una misma entidad, implicando —en términos tradicionales - éste la "visión comprensora" de lo fenoménico, aquélla en cambio la "visión" interior in absentia tanto de lo "ya visto" como lo "inventado" por el alma. Cabe asimismo destacar que Leonardo nunca esclarece la sugerida equipolencia con el senso commune, y que ingegno, immaginazione o fantasia (lo mismo que, con alguna excepción, intelletto o giudizio) se usan en contextos teóricos de naturaleza distinta (en el paragone con la poesía o indagando la propia praxis artística) sin ser explí-

66. "sensu communi, ut vocant, id est potentiâ imaginatrice". Meditationes II, 29; en Descartes, Euvres, vol. VII, 32.

67. Kemp establece esto a nivel funcional, a partir de la interacción entre lo imaginario y lo "racional" (aquí adjudicable al senso comune capaz de "juzgar"): "Since the faculty of reason, through which man comprehends Nature, and that of imagination, through which he recreates Nature, are so closely complementary, it is reasonable to suppose that immaginativa would have been sited with the sensus communis in the second ventricle". Kemp, "Il Concetto dell'Anima", I33-I34. En otro texto posterior, el mismo Kemp asevera que, a semejanza de lo que Dante hizo para la poesía y la fantasia, "Leonardo developed immaginazione-fantasia into the vital image-forming capacity for the painter. To do this, he relocated fantasia in the second ventricle of the brain where it could operate in close conjunction with invenzione and rational intellect". Martin Kemp, "From 'Mimesis' to 'Fantasia': The Quattrocento Vocabulary of Creation, Inspiration and Genius in the Visual Arts", Viator. Medieval and Renaissance Studies, núm. 8 (1977): 396; también del mismo Kemp, Leonardo da Vinci: The Marvellous Works of Nature and Man (Óxford: Oxford University Press, 2006), I08-1 10 y I46. Estas generalizaciones, que implican a la phantasía, el sensus communis, el iudicium, la ratio y el intellectus, son facilitadas por el desorden terminológico de Leonardo; sin embargo, no siempre tienen la suficiente base textual y obedecen a inferencias en parte fundadas, pero de varios modos cuestionables. Se trata, no hay duda, de materias muy inestables que pueden tratar de ordenarse, con resultados poco plausibles, en observaciones panorámicas como la de Klein: "Il serait d'ailleurs plus exact, en beaucoup de cas, de dire que l'imagination, identifiée avec la ratio au sens large, est le nom générique des sens intérieurs dans leur ensemble." Robert Klein, "L'imagination comme vêtement de l'âme chez Marsile Ficin et Giordano Bruno", en La forme et l'intelligible. Écrits sur la Renaissance et l'art moderne, ed. André Chastel, Bibliothèque des Sciences Humaines (París: Gallimard, 1970), 65. Tal aserto puede resultar muy poco exacto si no se fija el contexto concreto donde la voz es empleada, pues a menudo phantasia-imaginatio es algo nítidamente distinto de la ratio y del sensus communis. 
citamente vinculados con los textos anatómicos, en una compartimentación terminológica que en modo alguno favorece la mayor claridad conceptual. Añadidamente, los vocablos técnicos latinos, ya de por sí ambiguos y complejos, incrementaron su inestabilidad al ser vertidos a las lenguas modernas, donde se adaptan o se vinculan con voces ya en uso. ${ }^{68}$ En todo caso, que Leonardo sostuviese durante años la búsqueda de un esquema "personal" de las potencias interiores, a pesar de que debió manejar las obras de Galeno, Avicena, san Alberto Magno, Mondino y Benedetti ${ }^{69}$ (además de su vínculo con el profesor de anatomía en Pavia, Marcantonio della Torre), ${ }^{70}$ permiten sustentar que tanto la teoría sobre la impressiva como la subrayada principalía del sensus communis obedecen no a la "ignorancia" del artista, sino a un intento auténticamente "original" que — partiendo del esquema tripartito de la tradición "galénica” — buscó sus propias soluciones para explicar los procesos biopsicológicos de la cognición. Es notorio el énfasis en su cualidad sensoria, que constituye con claridad una tendencia definidamente leonardesca frente al problema epistemológico general.

\section{La capacidad especular e inventiva de la phantasia}

De cierto, lo "imaginario" está ligado con lo sensible en las doctrinas psicofisiológicas tradicionales; el vínculo es, si cabe, más estrecho en Leonardo, quien al ser uno de los mayores apologistas de lo visual lo fue también de la capacidad de la mente como entidad reproductora-comprensora de la realidad natural. Una de sus metáforas preferidas para representarla es la del espejo; el pintor debe "sobre todo ser de mente igual a la naturaleza que tiene la superficie del espejo, que se cambia en tantos diversos colores cuantos son los colores

68. Lo sugieren, para los casos comentados, las Questioni filosofiche (principios del siglo XIII) al implicar — más allá de su fuente latina - a la ratio, el iudicium y el sensus communis: "In lo iiij ${ }^{\circ}$ cap(ito)lo se demostra dove stane la me(m)oria, la fantasia e la rasgio(n)e ov(er)o el giudicio, el quale se chiama el senso comune in(per)ciò che iudica de tutti le sensora" (IV, 3, 4). "Questioni filosofiche" in volgare mediano dei primi del Trecento, ed. Francesca Geymonat, vol. 2 (Pisa: Scuola Normale Superiore, 2000), 92.

69. Kemp, “Il Concetto dell'Anima”, i I9. Hay notas que testimonian el interés y conocimiento directo de Leonardo sobre estos autores, por ejemplo The Literary Works, ed. Richter, \$ I42I, I469, I482, I483, I494.

70. Indicado por Paolo Giovio y Giorgio Vasari, y al parecer avalado por algunas de sus anotaciones: Kemp, Leonardo da Vinci: The Marvellous Works, 285. 
de los objetos" ${ }^{71}$ La diversidad de formas y colores ha de ser aprehendida interiormente con puntual precisión como una colección viva de reflejos; el pintor tiene que hacer de su mente un instrumento, en primera instancia, fundamentalmente receptivo, obteniendo del mundo una minuciosa y objetiva reproducción de las cosas externas ${ }^{72}$ a través del ojo que, en los aristotélicos términos de san Alberto, ${ }^{73}$ repetidos por Alberti, es un "espejo animado" (speculum animatum):74 "El ojo, del cual la belleza del universo es espejeada por los contempladores..."75 Cabe reparar en que la imagen del espejo corresponde al sentido común (como ocurre en Avicena) ${ }^{76}$ no menos que, previsiblemente, a la phantasía. Así, Plotino aludía a la razón que, haciendo pasar el objeto de conocimiento "desde el pensamiento a la [facultad] fantástica, lo mostró como en un espejo” (Enneades IV, 3, 30, 9-Io). También, refiriéndose a las proteicas formas de lo aparencial y sus manifestaciones pasadas, presentes y futuras, Sinesio indicó: "De todas estas imágenes cambiantes el espíritu fantástico es espejo que muy claramente las muestra” (De insomniis XV, I49C).

7I. "sopra tutto essere di mente equale alla natura che ha la superfizie dello specchio, la quale si trasmuta in tanti vari colori, quanti sono li colori delli sua obbietti”. Leonardo, Codex Atlanticus, I84v c., en Da Vinci, Scritti scelti, 463; y The Literary Works, ed. Richter, $\$ 493$.

72. En el caso de limitarse a una sola cosa, como los retratistas, fallarán en la composición de la historia, prefiriendo lo particular sobre lo universal; ello lo ilustra a través de otro símil especular: "Essendo la potenzia di tale ingegno ridotta in poco spazio, non ha potenzia nella dilatazione, e fa questo ingegno a similitudine dello specchio concavo, il quale pigliando li razzi del sole, quando reflette essa quantità di razzi in maggiore somma di dilatazione, li refletterà con più tepida caldezza, e quando esso li reflette tutti in minore loco, allora tali razzi so' d'immensa caldezza, ma adopra in poco loco. Tal fanno questi tali pittori non amando altra parte della pittura che 'l sol viso de l'omo". Da Vinci, Libro di Pittura, \$ 58, I72-I73 [ca. I500-I505].

73. "Si igitur oculus est quoddam speculum animatum, sicut dicit Philosophus"/ "organum imaginis est sicut speculum animatum”. San Alberto, Summa de creaturis II, q. 2I, art. 3, pars 3; q. 4, 3 y II, q. 42, art. I, sol., en Opera omnia, ed. Augustus Borgnet, vol. 35 (París: Ludovicus Vivès, I896) I99b y $360 a$. Véase Aristóteles, De sensu et sensato 438a-b.

74. Leon-Battista Alberti, De pictura I, 6, en Das Standbild, Die Malkunst, Grundlagen der Malerei, eds. Oskar Bätschmann y Christoph Schäublin (Darmstadt: Wissenschaftliche Buchgesellschaft, 2000), 202. "L'œil est comme le miroir". Avicena, Le Livre de science, eds. Mohammad Achena y Henri Massé, vol. 2, Physique, mathemátiques (París: Les Belles Lettres, I958), 60 .

75. "L'occhio, del quale la bellezza de l'universo è specchiata dalli contemplanti..." Da Vinci, Libro di Pittura, $\$ 24$, I48 [ca. I490-I492].

76. "le sens commun est comme un miroir; si le sens externe perçoit une forme, elle se reflète dans ce miroir, alors il y a perception". Avicena, Le Livre de science, 85 . 
La vis phantastica es la potencia que sirve como espejo interior, tanto de las formas dianoéticas de la cognición espiritual como de las exteriores que, aprehendidas en ella, otorgan la posibilidad básica de todo proceso epistemológico. No es de extrañar que Ramon Llull haya señalado que "el espejo sea principalmente imagen y signo de la imaginación"; 77 se trata de un modelo metafórico-conceptual de uso más o menos tópico, como corrobora Landino: "la cogitativa volviéndose hacia la imaginativa encontró allí estas imágenes de modo no distinto que si las viese en un espejo" ${ }^{78}$ De bella forma, Giordano Bruno sugerirá que el spiritus phantasticus es, frente al ojo corpóreo, un "espejo vidente" que implica la unidad subjetivo-objetiva de la conciencia; ${ }^{79}$ en él se cifra una condición primordial de la mente y el alma del hombre, "his glassy essence", ${ }^{80}$ como dirá Shakespeare (Measure for Measure II, II, I23).

Para Leonardo, por su parte, esta equipolencia es más que metafórica y se concreta en ejercicios de prueba donde la phantasía demuestre constituirse en fidedigna réplica de la realidad:

Cuando quieras saber una cosa bien estudiada en la mente, haz de este modo: esto es, cuando hayas dibujado una misma cosa tantas veces que te parezca tenerla en la mente, prueba a hacerla sin el modelo, y ten trazado a contraluz sobre un vidrio delgado y plano tu modelo y ponlo sobre la obra que ha sido hecha sin el ejemplo presente; y nota bien donde el vidrio no se corresponda con tu dibujo; y donde veas haber errado, retenlo allí en mente para no equivocarte más, luego retorna al modelo para reproducir tantas veces aquella parte equivocada hasta que la tengas bien en la imaginativa $[\ldots]^{8 I}$

77. "speculum sit maxime imago et signum imaginationis" (I I, 5, 485-486, 537). Ramon Llull, Ars generalis ultima, vol. 75 de Corpus Christianorum Continuatio Mediaevalis, ed. Aloisius Madre (Turnhout: Brepols, 1986), 433.

78. "la cogitativa sua voltandosi alla imaginativa vi trovò queste imagini non altrimenti che se le vedessi nello spechio" (Inferno XXIII, 19-24, 68-70). Landino, Comento sopra la Comedia, vol. 2, 818.

79. "Tandem differt oculi visus a visu interni spiritus, quemadmodum speculum videns a speculo non vidente, sed tantum repraesentante speculum se ipso illuminatum et informatum, quodque simul lux est et speculum, et in quo obiectum sensibile cum subiecto sensibili sunt unum." Bruno, De compositione imaginum liber I, XII, en Opera, vol. 3, I I9.

8o. William Shakespeare, The Complete Works (Compact Edition), eds. Stanley Wells y Gary Taylor (Óxford: Clarendon, I990), 798a. La comparación especular del alma, ya en Avicena: "et est anima quasi speculum" (V, vi), Liber De Anima, vol. 2, I46.

8I. "Quando tu vorrai sapere una cosa studiata bene a mente, tieni questo modo: cioè, 
A través de esta práctica asidua, la "mente" o la "imaginativa” prueba en su exacta ejecución la capacidad de captar y reproducir el objeto in absentia. Hay otras observaciones que abundan sobre esta capacidad reflectora de la realidad:

El ingenio del pintor busca ser a semejanza del espejo, que siempre se cambia en el color de aquella cosa que tiene por objeto, y de tantas semejanzas se llena cuantas son las cosas que le son colocadas delante. Así pues sabiendo tú, pintor, no poder ser bueno si no eres maestro universal de retratar con tu arte la cualidad de las formas que produce la naturaleza, las cuales no sabrás hacer si no las ves y retienes en la mente, entonces, andando por los campos, haz que tu juicio se dirija a diferentes objetos, y de tiempo en tiempo remira esta cosa o aquélla, haciendo un haz de varias cosas elegidas y seleccionadas de entre las menos buenas; $y$ no hagas como algunos pintores que, agotados en su fantasía, dejan la labor y se cansan andando a solaz, acumulando el agotamiento de la mente, no sólo porque vean o pongan en mente diversas cosas; pero a menudo encontrando a los amigos o parientes, siendo de ellos saludados, no obstante los ven o escuchan, no distintamente son conocidos como si llamasen lo mismo que al aire. ${ }^{82}$

quando tu hai disegnato una cosa medesima tante volte che te la paia avere a mente, pruova a farla sanza lo esemplo, e abbi lucidato sopra uno vetro sottile e piano lo esemplo tuo e porràilo sopra la cosa che hai fatta sanza lo esemplo; e nota bene dove il lucido non si scontra col disegno tuo; e dove truovi avere errato, lì tieni a mente di non errare più, anzi ritorna allo esemplo, a ritrarre tante volte quella parte errata, che tu l'abbia bene nella immaginativa [...]" Da Vinci, Codex Atlanticus, I04r, en Da Vinci, Scritti scelti, 214-2I5; The Literary Works, ed. Richter, $\$$ 531; y Da Vinci, Libro di Pittura, $\$ 72$, I80-I8I [ca. I 492].

82. "Lo ingegno del pittore vol essere a similitudine dello specchio, il quale sempre si trasmuta nel colore di quella cosa ch'elli ha per obietto, e di tante similitudine s'empie, quante sono le cose che li sono contraposte. Adunque conoscendo tu, pittore, non potere esser bono se non se' universale maestro di contraffare colla tua arte tutte le qualità delle forme che produce la natura, le quali non saprai fare se non le vedi e ritenerle nella mente, onde andando tu per campagne, fa' che 'l tuo giudizio si volti a vari obietti, e di mano in mano riguardare or questa cosa, or quell'altra, facendo un fascio di varie cose elette e scelte infra le men bone, e non facci come alcun pittore, i quali, stanchi co' la lor fantasia, dismettano l'opera e fanno esercizio co' l'andare a sollazzo, riserbandosi una stanchezza nella mente, la quale no' che vegghino o ponghin mente varie cose, ma spesse volte scontrando li amici o parenti, essendo da quelli salutati, non che li vedino o sentino, non altrementi sono cognosciuti come s'elli scontrassino altretant'aria. Lo ingegno del pittore vol essere a similitudine dello specchio, il quale sempre si trasmuta nel colore di quella cosa ch'elli ha per obietto, e di tante similitudine s'empie, quante sono le cose che li sono contraposte. Adunque conoscendo tu, pittore, non 
En este punto, es el ingegno del pintor el cual se reviste con la cualidad especular de la mente, que guarda la posibilidad metamórfica de recoger la vasta diversidad de las impresiones visuales, universalidad receptora que a su vez se vuelve en condición indispensable para la maestría artística. Lo que el artista debe desarrollar es una "fantasía sensible exacta" ("exakte sinnliche Phantasie"); ${ }^{83}$ sólo a través del robustecimiento de esa fidedigna captación es como puede cumplirse el fin mimético del arte y así evitar también otro tipo de "errores" (impuestos por la propia disposición expresiva del alma, "maestra del tuo corpo", y el giudizio que mueve a la mano) como la "autorrepresentación involuntaria" ("todo pintor se pinta a sí mismo"). ${ }^{84}$ Pero además, en este proceso la mente debe retener las imágenes; es decir, se apunta también su capacidad memoriosa. Asimismo, se añade el necesario discernimiento que ofrece el giudizio, como la facultad que permite proceder a una selectio de imágenes, mediante la cual se guarda sólo una "colección" de las mejores para ser utilizadas como materia creadora. Por su parte, la laboriosidad del ingenio queda contrastada negativamente a través de aquellos "fatigados con

potere esser bono se non se' universale maestro di contraffare colla tua arte tutte le qualità delle forme che produce la natura, le quali non saprai fare se non le vedi e ritenerle nella mente, onde andando tu per campagne, fa' che 'l tuo giudizio si volti a vari obietti, e di mano in mano riguardare or questa cosa, or quell'altra, facendo un fascio di varie cose elette e scelte infra le men bone, e non facci come alcun pittore, i quali, stanchi co' la lor fantasia, dismettano l'opera e fanno esercizio co' l'andare a sollazzo, riserbandosi una stanchezza nella mente, la quale no' che vegghino o ponghin mente varie cose, ma spesse volte scontrando li amici o parenti, essendo da quelli salutati, non che li vedino o sentino, non altrementi sono cognosciuti come s'elli scontrassino altretant'aria". Da Vinci, Codex Atlanticus, 82r, en Da Vinci, Scritti scelti, I88; y The Literary Works, ed. Richter, \$506.

83. Según la expresión de Goethe, aplicada apologéticamente a Leonardo por Ernst Cassirer, Individuum und Kosmos in der Philosophie der Renaissance (Leipzig/Berlín: Teubner, I927), I67.

84. "Ogni pittore dipinge sé”. Da Vinci, Libro di Pittura, \$108-109, I93-194; sobre sus bases históricas y teóricas (la tendencia naturalista de Leonardo y el senso comune como estructura central del alma y sus directrices a priori) y la necesidad de la asiduidad dibujística y los estudios científicos contra la "involuntaria automímesis", véase lo expuesto por Frank Zöllner, "Dall'artista legato a commissioni all'artista d'espressione: Leonardo e Michelangelo", en L'opera grafica e la fortuna critica di Leonardo da Vinci. Atti del Convegno internazionale. Parigi, Musée du Louvre, I6-I7 maggio 2003, eds. Pietro C. Marini y Françoise Viatle (Florencia/Milán: Giunti, 2006), I02-I07; y "Kunst und Wissenschaft: Leonardo zwischen 'automimesis' und Proportionslehre”, Denkströme. Journal der Sächsischen Akademie der Wissenschaften, núm. 3 (2009): 42-57. 
su fantasía” que, sin esforzarse en cumplir la labor conceptual de las obras y el proceso de visión-selección-retención de imágenes, divagan y por mero placer inducen el "agotamiento de la mente", sin potenciar el espejo totalizador de ingenium-phantasía — incansable en un artista como Leonardo- y su trabajo visual-comprensor-memorístico como instrumento privilegiado del proceso formatorio del pintor. Sin la phantasía autoconsciente, personas y cosas se tornan vana phantasmata que no dejan "impresión” alguna en la mente.

Debe, por otra parte, notarse que de la interrelación de la phantasía y el ingenium hay diversos indicios en las teorías sobre los sentidos interiores desarrolladas desde la Antigüedad. Por ejemplo, a partir de la división tripartita de las potencias del alma, de origen aristotélico-galénico y que gozó de una considerable difusión en la Edad Media, en algunos textos, en particular de la escuela de Chartres, se sugirió la concurrencia entre el ingenium y la vis phantastica en tanto que ocupan el primer ventrículo del cerebro; valga como muestra un texto de Guillermo de Conches:

Tres son las cosas que hacen de modo perfecto al sabio: el ingenio, esto es, la potencia natural para entender algo con rapidez; la razón, que es el discernimiento de los inteligibles; y la memoria de las cosas pasadas. Si no sabe alguien entender, discernir y retener en la memoria, no es completamente un sabio; y si esto sabe, sabio es. En verdad estas tres cosas, que hacen perfecto al sabio, tienen su sede en la cabeza. Está ciertamente en la primera parte de la cabeza la celdilla del cerebro en que se encuentra la potencia de entender que es llamada fantástica. ${ }^{85}$

85. "Tria sunt quae faciunt perfecte sapientem: ingenium, id est naturalis uis ad aliquid cito intelligendum; ratio, id est discretio intellectorum; memoria praeteritorum. Nisi sciat aliquis intelligere, discernere, in memoria retinere, non est perfecte sapiens; et si ista sciat, sapiens est. Ista uero tria, quae perfecte faciunt sapientem, in capite habent sedem. Est enim in prima parte capitis cellula cerebri in qua est uis intelligendi quae uocatur fantastica" (In Consolationen I, pr. I, 39-46). Guillermo de Conches, Glosae super Boetium, vol. I5 8 de Corpus Christianorum Continuatio Mediaevalis, ed. L. Nauta (Turnhout: Brepols, 1999), I9. Asimismo, en el comentario a la Eneida atribuido a Bernardo Silvestre: "Minerva quasi media vel intima cogitatio est, sapientia que in cerebro sedem habet. Tria namque sunt que sapientiam perfectam reddunt, ingenium, scilicet vis inveniendi, ratio vis discernendi inventa, memoria vis conservandi. In cerebro autem sunt tres cellule quas alii ventriculos vocant: prima anterior in qua est ingenii exercicium; secunda est mediana in qua est vis rationis; tercia est postica in qua est vis memorie" (Commentum super sex libros Eneidos Virgilii VI, 68); y "Tria enim scientia naturalia habet seminaria: ingenium, vim naturalem inveniendi; rationem, vim scilicet discernendi inventa; memoriam, vim conservandi discreta" (VI, 334). Bernardo 
De este modo, las corroborables confusiones en la tradición facilitan entender la diversidad terminológica de los apuntes leonardescos; pues, en efecto, los procesos atribuidos al sensus communis, al ingenium y a la phantasía o la imaginatio poseían un fondo conceptual concurrente en la movediza nomenclatura medieval sobre los sentidos interiores y cuyo deslinde resultaba, en muchos casos y contextos, bastante problemático.

Ahora bien, es sobre todo interesante destacar que el proceso mismo de creación es el que fundamentalmente parece ser referido por Leonardo como propio de la phantasía en, al menos, ese status de equivalencia con el ingenium. Por ejemplo, en disputa con la poesía: "si la llaman mecánica, porque es obra manual, ya que las manos forman aquello que encuentran en la fantasía, ustedes escritores, dibujando con la pluma manualmente aquello que en vuestro ingenio se encuentra..." ${ }^{86}$ Es decir, que ingegno y fantasia son explícitamente utilizados para referir a la facultad que da origen a la "creación" artística (en este punto, pintura y poesía igualados también en términos de "artes mecánicas" por la semejante labor operativa del pincel y la pluma); y fantasia es en particular usada para el caso del arte pictórica. Ello testimonia que Leonardo usaba también la palabra en términos positivos, e incluso, no parece considerar aquí alguna valoración peyorativa que hiciere inoportuno introducirla en el espinoso terreno del laudo y la polémica con su rival artística. También emplea el término immaginativa para referirse a la aprehensión interior del objeto, el cual debe ser reproducido de memoria y luego contrastado con el original hasta "que lo tengas bien en la imaginativa". ${ }^{87}$ Igualmente, comenta cómo de modo inicial lo que se dibuja es "la intención y la invención hecha

Silvestre, The Commentary on the First Six Books of the "Aeneid" Commonly Attributed to Bernardus Silvestris, eds. Julian Ward Jones y Elizabeth Frances Jones (Lincoln/Londres: University of Nebraska, I977), 47 y 8I-82.

86. "Se voi la chiamate meccanica, perchè è opera manuale, che le mani figurano quel che truovano nella fantasia, voi scrittori, disegnando colla penna manualmente quello che ne lo ingegno vostro si truova”. Da Vinci, Codex Atlanticus, 99r-v, en Da Vinci, Scritti scelti, 204; y The Literary Works, ed. Richter, $\$ 654$. Dirá Palomino: "pues si se extendiese la voz mecánica en el estilo de su vulgar sonido, no habría arte liberal (especialmente de las matemáticas) que no fuese mecánica” (I, II, IV, $\mathbb{\$}$ II). Antonio Palomino de Castro y Velasco, El museo pictórico y escala óptica, pról. Juan de Ceán y Bermúdez (Madrid: M. Aguilar, I947), I67a.

87. "che tu l'abbia bene nella immaginativa". Leonardo, Codex Atlanticus, Io4r, en Da Vinci, Scritti scelti, 215. 
primero en tu imaginativa" ${ }^{88}$ No abunda mayormente en esto, pero deja con todo expresado de manera suficiente que la inventio pictórica es, en efecto, obra de phantasía-imaginatio. Un dictum que puede no resultar, desde una óptica moderna, muy sorprendente, y el cual muestra una continuidad nominal respecto de Cennini ${ }^{89}$ o Filarete, ${ }^{90}$ pero que no será tan a menudo sostenida, en tales términos, por otros autores de teorías de la pintura en el horizonte renacentista-barroco.

Nótese que la distante actitud de Leonardo frente a las formas más “intangibles" del idealismo no promueve un desdén generalizado por lo imaginario, sino que permite comprenderlo como fuente de visión anímica, como aparato replicante del mundo el cual confiere al hombre la base de toda certeza gnoseológica y reconocido como el espacio creativo connatural al pintor. En este sentido, y para la propia manera posromántica de entender el tema, la concepción leonardesca puede incluso llegar a producir un malentendido inverso al en ocasiones supuesto sobre el Renacimiento — que la facultad fantástica no existe como categoría conceptual porque llega a ocultarse en una diversa nomenclatura-, lo cual amerita su correspondiente aclaración. En efecto, no es la suya, al modo de los románticos, la enunciación explícita de una fantasía como potencia sintética de lo espiritual invisible y lo material sensible a manera de una Einbildungskraft transcendental. La phantasia, fronteriza entre lo sensible y lo racional, muestra en la teoría de Leonardo su capacidad reproductora del mundo dado a los sentidos, y conserva el valor que la propia palabra guardaba para san Agustín, como recuerdo de una imagen sensoria, ${ }^{91}$ aunque también pueda confundirse con el phantasma de origen no directamente sensible. Ciertamente, al apuntar la unidad interior de la inventio a par-

88. "la intenzione e la invenzione fatta in prima nella tua immaginativa". Da Vinci, Codex Atlanticus, I06r, en Da Vinci, Scritti Scelti, 22 I; y The Literary Works, ed. Richter, \$502.

89. "e quest'è un'arte che si chiama dipignere, che conviene avere fantasia e operazione di mano”. Cennino Cennini, Il libro dell'arte, ed. Franco Brunello, intr. Licisco Magagnato, $2^{\mathrm{a}}$ ed. (Vicenza: Neri Pozza, I982), I , 3-4.

90. Dicho del arquitecto y el edificio: "Ma innanzi che lo partorisca, come proprio la donna che nove o sette mesi in corpo lo porta [...] così l'architetto debba nove o sette mesi fantasticare e pensare e rivoltarselo per la memoria in più modi, e fare varii disegni nella sua mente sopra al generamento che lui ha fatto col padrone" (II). Antonio Averlino (detto il Filarete), Trattato di architettura, eds. Anna Maria Finoli y Liliana Grassi, vol. I (Milán: Il Polifilo, I972), 40 [7 v]; y del arquitecto ideal: "Bisogna che sia ingegnoso e che immagini di fare varie cose e di sua mano dimostri” (XV), vol. 2, 428 [II $3 \mathrm{r}-\mathrm{v}$ ].

91. Véase De musica (VI, xI), vol. 32 de Patrologia Latina (París: J.-P. Migne, I84I), col. I I80. 
tir de ella, permite entrever otro de los sentidos posibles de ese puente teórico entre el Renacimiento y el romanticismo y momentos posteriores — que en el barroco adquirirá expresiones más próximas al ideario romántico-, a veces oculto bajo la niebla de una terminología tornadiza y problemática; pone, de esta forma, a la vista la necesidad de analizar en qué términos tiene lugar el desarrollo de las reflexiones sobre arte en la modernidad europea, tanto en sus singularidades históricas como en su necesaria continuidad.

\section{La definición polémica del Paragone y el occhio tenebroso de la imaginación}

En el famoso Paragone entre la pintura y la poesía —álgido capítulo de la larga "disputa sobre el primado de las artes" que se extiende hasta el barroco-,${ }^{92}$ phantasía-ingenium aparecen como las facultades productoras de la inventio pictórica y poética. Ambas han sido vinculadas tanto por su potencial universalidad temática como por la libertad de su poder creativo, desde los famosos versos de Horacio: "para los pintores y los poetas de atreverse a todo siempre ha sido igual la potestad".93

No olvida Leonardo que el "poeta es libre, como el pintor, en las invenciones"; 94 es decir, sus phantasíai son igualmente autónomas (con la siempre latente problemática de sus límites, pues "donde hay libertad no hay regla").95 Pero a partir de esta unidad esencial tiene lugar, como es sabido, la

92. La importancia teórica de estas comparaciones, que supera la mera "esercitazione accademica" convirtiéndose en agente catalizador de un más intenso desarrollo lingüístico y conceptual, ha sido destacada por Paola Barocchi, en Scritti d'arte del Cinquecento, ed. Paola Barocchi, vol. I (Milán y Nápoles: Ricardo Ricciardi, I97I), 465. En tiempos de Leonardo, Jean Lemaire de Belges incluye el asunto de la superioridad, en su caso, de la poesía sobre la pintura en La Plainte du Désirée (I504; "el primer texto en francés en el que la pintura como arte es tematizada"); véase el contraste entre ambos autores esbozado por Suzanne Kooij, "Poetic-Imagination and the Paradigm of Painting in Early-Modern France", en Imagination in the Later Middle Ages and Early Modern Times, eds. Lodi Nauta y Detlev Pätzold (Lovaina/ París/Dudley: Peeters, 2004), 86-90.

93. "'pictoribus atque poetis/quidlibet audendi semper fuit aequa potestas" (De arte poetica 9-Io; ed. D. R. Shackleton Bailey [Stuttgart: Teubner, I985]).

94. "poeta è libero, come 'l pittore, nelle invenzioni". Da Vinci, Codex Atlanticus, 99r-v, en Da Vinci, Scritti scelti, 203; The Literary Works, ed. Richter, $\$ 653$; y Da Vinci, Libro di Pittura, \$I9, I43 [ca. I 492].

95. “dove è libertà non è regola”. Da Vinci, Libro di Pittura, \$ I24, I99 [ca. I 492]. 
reformulación del viejo tópico del ut pictura poesis en términos de un ventajoso reposicionamiento para las artes plásticas. La fórmula antigua, según el testimonio de Plutarco, afirmaba: "Y en verdad Simónides llama a la pintura poesía que calla, y a la poesía pintura que habla" (De gloria atheniensium 3, 346F). Este símil, atribuido al poeta Simónides, ${ }^{96}$ se expresa para la pintura en términos de un déficit, como poesía carente de habla, mientras la poesía resultaba, por contraste, la pintura con el plus de ser "elocuente". Dos milenios más tarde, la plástica propone, por boca de Leonardo, su propia analogía: "si pretendieras que la pintura es 'poesía muda', igualmente el pintor podrá decir del poeta 'pintura ciega': mira luego cuál es más nocivo monstruo, o ciego o mudo" ${ }^{97}$ La poesía: "pintura ciega"; $9{ }^{8}$ ahora es ésta la que, desde su dominio, califica a aquélla y pone a la vista el carácter "monstruoso" del tópico, preparando así el terreno para la inversión leonardesca de la jerarquía de las artes, donde la representación visual revela su primado sobre la verbal. En efecto, la base de esa revaloración la otorga la ya comentada superioridad de lo visible sobre lo audible: "Y si el poeta sirve al sentido por la vía del oído, el pintor por el ojo, más digno sentido". 99 Puede decirse que, en este terreno, es la patencia la que se establece como categoría de excelencia de lo pictórico; algo que involucra a la phantasía como percepción: la propia a la pintura es más precisa y "real" que la accesible al lenguaje ("si la poesía se explaya con las palabras a figurar formas, hechos y sitios, el pintor se mueve con las propias semejanzas de las formas a retratar esas formas; ahora mira qué es más próximo al hombre:

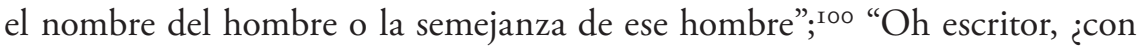

96. Véanse los demás loci clásicos: Rhetorica ad Herennium IV, 38 (ed. F. Marx [Leipzig: Teubner, I923]); Horacio, De arte poetica, 36I; Plutarco, De audiendis poetis 3, I7F; Quomodo adulator ab amico internoscatur I5, 58B; Quaestiones convivales 748A (eds. M. Pohlenz et al. [Leipzig: Teubner, 1925-1978]).

97. "se tu dimanderai la pittura muta poesia, ancora il pittore potrà dire del poeta orba pittura: or guarda quale è più dannoso mostro, o cieco o muto". Da Vinci, Codex Atlanticus, 99r-v, en Da Vinci, Scritti scelti, 203; y Da Vinci, Libro di Pittura, \$ I9, I43 [ca. I492].

98. También: "La pittura è una poesia muta, e la poesia è una pittura cieca, e l'una e l'altra va imitando la natura quanto è possibile alle loro potenzie, e per l'una e per l'altra si pò dimostrare molti morali costumi, come fece Apelle con la sua Calunnia". Da Vinci, Libro di Pittura, \$21, I45 [ca. I490-I492].

99. "E se il poeta serve al senso per la via de l'orecchio, il pittore per l'occhio, più degno senso". Da Vinci, Codex Atlanticus, 99r-v, en Da Vinci, Scritti scelti, 203-204.

Ioo. "se la poesia s'astende colle parole a figurare forme, atti e siti, il pittore si move colle proprie similitudine de le forme a contrafare esse forme; or guarda qual'è più propinqua 
qué letras escribirás tú con tal perfección la figura entera como hace aquí el dibujo?"). ${ }^{\text {Ior }}$ Así también, por el color, la perspectiva y su capacidad multirrepresentativa, la pintura se revela como un arte más completo y perfecto que la escultura; por ello, "la pintura es más bella y de mayor fantasía y más rica", ${ }^{102}$ y la escultura resulta de "menor ingenio". ${ }^{\text {I03 }}$

Dicha superioridad de la pintura sobre la poesía lleva a Leonardo a adoptar la célebre enunciación del arte como "nieto de Dios", expresada por Dante en la Commedia con base en preceptos aristotélicos:

Filosofía, me dijo, a quien la entiende, muestra, y no sólo en una única parte, cómo natura su curso lo prende del divino intelecto y de su arte; si atiendes de tu Física el concepto, verás presto en sus folios sin cansarte: vuestra arte cuanto puede su precepto sigue, como al maestro el estudiante; así de Dios vuestra arte es casi un nieto. ${ }^{104}$

La de Dante es, de hecho, una afirmación abierta a todo arte humano. Por ello no resulta muy difícil a Leonardo afirmar que "Nosotros por el arte pode-

all'omo o 'l nome d'omo, o la similitudine d'esso omo". Da Vinci, Codex Atlanticus, 99r-v, en Da Vinci, Scritti scelti, 203; y The Literary Works, ed. Richter, $\$ 653$.

Iог. "O scrittore, con quali lettere scriverrai tu con tal perfezione la intera figurazione, qual fa qui il disegno?" Da Vinci, "Fogli d'anatomia posteriori al I50o", Codex Windsor, RL 1907I, en Da Vinci, Scritti scelti, 508.

I02. "la pittura è più bella e di più fantasia e più copiosa". Da Vinci, Codex Atlanticus, I04v, en Da Vinci, Scritti scelti, 218; The Literary Works, ed. Richter, $\$ 656$; y Da Vinci, Libro di Pittura, $\$ 38, \mathrm{I} 62$ [ca. I492].

103. "minore ingegno". Da Vinci, Codex Atlanticus, I04v, en Da Vinci, Scritti scelti, 217; The Literary Works, ed. Richter, $\$ 655$; y Da Vinci, Libro di Pittura, $\$ 38$, I6I [ca. I 492].

I04. "'Filosofia', mi disse, 'a chi la 'ntende, / nota, non pure in una sola parte, / come natura lo suo corso prende // dal divino 'ntelletto e da sua arte; / e se tu ben la tua Fisica note, / tu troverai, non dopo molte carte, // che l'arte vostra quella, quanto pote, / segue, come 'l maestro fa 'l discente; / sì che vostr' arte a Dio quasi è nepote'" (Inferno XI, 97-I05). Dante Alighieri, La Commedia secondo l'antica vulgata, ed. Giorgio Petrocchi, vol. 2 (Milán: Arnoldo Mondadori [Società Dantesca Italiana, Edizione Nazionale], I966), I87-I88. 
mos ser llamados nietos de Dios", ${ }^{\text {IOS }}$ cuyo contexto polémico parece esbozar cierto enfrentamiento del pintor con el maestro de la poesía italiana. Además de esta pincelada, en otro apunte reescribe abiertamente la expresión dantesca al considerar que, "por decir más correcto", en cuanto imitadora directa de los seres y objetos naturales (como "hijos" de la naturaleza), se le debe llamar "nieto de la naturaleza y pariente de Dios". ${ }^{\text {106 }}$ Esta reformulación por parte de Leonardo resalta su postura personal y su intención rearticuladora de nociones que, surgidas en el ámbito de la poesía, son ahora adecuadas para la pintura; al tiempo que demarca su independencia intelectual, se sirve de ellas para definir los rasgos de sus propias valoraciones e inquietudes artísticas. Por ello, vuelve a utilizar el concepto de Dante confiriéndole otro matiz; según Leonardo, nipoti de la naturaleza son los pintores que copian sólo a los maestros de su arte y no a la naturaleza misma: "aquellos que solamente estudian a los autores y no las obras de la naturaleza, son por el arte nietos y no

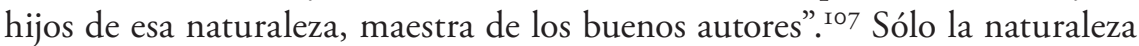
es, según mostró Masaccio, la verdadera "maestra de maestros". ${ }^{108}$

En el mismo contexto de la disputa con la poesía, debe notarse que la phantasía constituye también un elemento diferenciador in malo, por supuesto, para ésta. Por un lado, un distingo radica en la "materia" (subbietto) propia a una y otra arte: "más vale una imaginación falsa de la esencia de Dios, que una imaginación de una cosa menos digna". ${ }^{\circ 09}$ Mientras que la poesía sólo ofrece "mentirosas ficciones de las obras humanas", las fabricaciones del lenguaje (no "las obras de la naturaleza" sino "las obras del operador, es decir las obras de los hombres, que son las palabras"), ${ }^{\text {Io }}$ la pintura muestra las "co-

I05. "Noi per arte possiano essere detti nipoti a Dio". Da Vinci, Codex Atlanticus, 99r-v, en DaVinci, Scritti scelti, 204.

Io6. "nipote di natura e parente di Dio". Da Vinci, Codex Atlanticus, Ioor, en Da Vinci, Scritti scelti, 206; The Literary Works, ed. Richter, $\$ 652$; y Da Vinci, Libro di Pittura, $\$$ I2, I37 [ca. I 492].

I07. "quegli che solamente studiano li altori e non l'opere di natura, sono per arte nipoti e non figlioli d'essa natura, maestra de' boni altori”. Da Vinci, Codex Atlanticus, I4 I r b, en Da Vinci, Scritti scelti, 239. Vid. Da Vinci, Libro di Pittura, \$ 8I, I84 [ca. I508-I5I0].

I08. Da Vinci, Codex Atlanticus, I4 I r b, en Da Vinci, Scritti scelti, 239; The Literary Works, ed. Richter, $\$ 660$.

I09. "più vale una falsa immaginazione della essenzia d'iddio, che una immaginazione d'una cosa men degna”. Da Vinci, Libro di Pittura, \$27, I5 I [ca. I 490-I 492].

I Io. "l'opere del'operatore, cioè l'opere degli omini, che sono le parole". Da Vinci, Libro di Pittura, \$ 7, I34 [ca. I500-I505]. 
sas mismas", res non verba. Ambas, en efecto, son phantasiae, pero el mayor apego a lo que la cosa es, es decir, su misma presencia natural, convierte a las palabras en "imaginaciones" de segundo grado que tratan de referir la materialidad de un modo precario e inconveniente. Esto podría implicar también el ámbito temático de su pertinencia, uno el de la "filosofía natural" que toca a la pintura, el otro, la "filosofía moral" de la poesía, ${ }^{\text {II }}$ contraposición concurrente con el superior grado de la cosmicidad sobre el "reino ético", éste como "ficticio" respecto de aquél desde el punto de vista de la "matematización" del mundo (criterio combatido en la modernidad por "filósofos del espíritu”, de Hegel a Dilthey y aun el propio Heidegger, pero con posibles expresiones correlatas en los pensadores científicos como Einstein o Russell); aunque los acerque, por otra parte, la necesidad de un talento nato para ejercer — como la poesía — el arte, en contraste con la matemática. ${ }^{\text {II2 }}$ Ello remite además a la naturaleza misma de la representación, que la pintura vuelve a mostrar, bajo la forma propia a los entes, al sentido supremo, la vista. En efecto, aunque se asuma la existencia de una "visión imaginaria", el ojo es superior a la phantasía ("No ve la imaginación con tanta excelencia como ve el ojo"); ${ }^{\text {II3 }}$ el poeta, que no puede hacer exteriormente visibles las cosas, tiene que apelar a ese sucedáneo procedimiento interior ("se encuentra la poesía en la mente, o sea la imaginativa del poeta”). ${ }^{I}{ }^{14}$ Esto, argumenta Leonardo, señala otra vez la primacía del arte pictórica:

Así pues, para tal modo de ficción diremos con verdad que hay tanta desproporción de la ciencia de la pintura con la poesía, como hay del cuerpo con su sombra derivada, y aun desproporción mayor, ya que la sombra del cuerpo al menos entra por el ojo al sentido común, pero la imaginación del cuerpo no entra en ese sentido, sino allí

I I. Da Vinci, Libro di Pittura, \$ I9, I44 [ca. I492].

I I2. "questa [la pintura] non s'insegna a chi natura nol concede, come fan le matematiche, delle quali tanto ne piglia il discepolo, quanto il maestro gli ne legge". Da Vinci, Libro di Pittura, $\$ 8$, I35 [ca. I500-I505]. Por supuesto, Leonardo no invoca a este propósito a la poesía, en esa paridad que será más o menos común en momentos posteriores.

I 3 . "Non vede la immaginazione cotal eccellenzia qual vede l'occhio". Da Vinci, Libro di Pittura, \$ I5, I39 [ca. I500-I505].

I 4. "si trova la poesia nella mente, overo immaginativa del poeta". Da Vinci, Libro di Pittura, \$ I5, I39 [ca. I500-1505]. 
se genera, en el ojo tenebroso. Vaya diferencia que hay entre imaginar tal luz en el ojo tenebroso, a verla en acto fuera de las tinieblas. ${ }^{\text {II }}$

De este modo, la "visión interior" de la que depende la poesía es, comparada con la vista "en acto", enormemente defectiva; es como la sombra de un cuerpo, y menos que eso, pues ni siquiera es avistable como aquélla y aprehensible en el sentido común; la imagen que "nace" en la fantasía, en esa visión "en tinieblas" de la interioridad, tiene así respecto de la presencia sensible un valor secundario, imperfecto y "sombrío".

Sea que los conociese, ${ }^{\mathrm{II} 6} \mathrm{o}$ - lo que es más probable — llegase a formulaciones semejantes por su genial intuición, Leonardo no sólo saca provecho a la idea sobre las condiciones generales de "debilidad de la imaginación", ${ }^{117}$ sino que parece también concordar con viejos conceptos de las teorías teológicas sobre las potencias interiores, donde, como afirmaba Hugo de San Víctor: "en verdad la imaginación, en cuanto es imagen del cuerpo, es sombra"; ${ }^{118}$ de un modo semejante, parece haber instrumentado, sin invocar la solución inspirada de la manía, los argumentos platónicos sobre el imposible saber universal de los poetas. ${ }^{\text {II }}$

I I5. "Adunque in tal caso de finzione diremo con verità essere tal proporzione dalla scienzia della pittura alla poesia, qual è dal corpo alla sua ombra derivativa, et ancora maggiore proporzione, con ciò sia che l'ombra di tal corpo almeno entra per l'occhio al senso comune, ma la immaginazione di tale corpo non entra in esso senso, ma lì nasce, in l'occhio tenebroso. O che differenzia è a imaginar tal luce in l'occhio tenebroso, al vederla in atto fuori delle tenebre". Da Vinci, Libro di Pittura, $\$$ I5, I39-I40. Igualmente: “Tal proporzione è dalla immaginazione a l'effetto qual è da l'ombra al corpo umbroso, e la medesima proporzione è dalla poesia alla pittura, perché la poesia pon le sue cose nella immaginazione de lettere, e la pittura le dà realmente fori de l'occhio". Da Vinci, Libro di Pittura, \$2, I32 [ca. I500-I505].

I 16. Kemp ha sugerido en los textos posteriores a I500 un acercamiento mayor a las teorías tradicionales sobre la imaginatio (Kemp, "From 'Mimesis' to 'Fantasia”, 380). En este caso, como imago in absentia rei, aunque el aspecto "sombrío" destacado por Leonardo es más bien propio de las objeciones teológicas contra la phantasía (la verdadera luz interior es la inteligible), por lo que parece probable que esta posición nazca de modo conducente a partir de sus propias concepciones empiristas. Es por demás notorio que su solución "personal" en la disposición de las potencias interiores no se modificó en los textos más tardíos que tocan el tema.

I I7. De la que habla por ejemplo Avicena, por la fuerza que en vigilia tienen los sentidos, el sentido común y la razón que somete a la imaginación. Avicena, Le Livre de science, vol. 2, 85 .

I 18. "imaginatio vero, inquantum corporis imago est, umbra est". De unione corporis et spiritus, vol. 77 de Patrologia Latina (París: J.-P. Migne, I880), col. 288A, col. 288A-B.

I I9. "ma se voi vestirti de l'altrui scienzie separate da essa poesia, elle non sono tue, come astrologia, rettorica, teologia, filosofia, geometria, aritmetica e simili; tu non sei allora poeta, 
Así, a falta de la presencia visible, ha de verse por "l'occhio tenebroso" de la immaginazione, que mira sólo en las "tinieblas" interiores. Es una versión, en efecto, "sombría" de un concepto heredado de la Antigüedad y el pensamiento medieval en la metáfora platónica del "ojo del alma", der, con clara propiedad, también a la imaginatio como facultad anímica de

tu ti trasmuti, e non sei più quello di che qui si parla”. Da Vinci, Libro di Pittura, $\$$ I 4 , I38 [ca. I500-I505], "nissuna di queste cose di che lui parla è sua professione propria, ma che se lui vole parlare et orare, è da persuadere ch'in questo gli è vinto da l'oratore; e se parla d'astrologia, che l'ha rubato allo astrologo, e de filosofia, al filosofo, e che in effetto la poesia non ha propria sedia, né la merita altramente che d'un merciaio ragunatore de mercanzie fatte da diversi artigiani”. Da Vinci, Libro di Pittura, \$23, I48 [ca. I490-I 492]. El poeta no es otra cosa que "uno adunatore de cose rubate a diverse scienzie, con le quali lui fa un composto bugiardo, o voi, con più onesto dire, un composto finto”. Da Vinci, Libro di Pittura, $\mathbb{\$} 32$, I56 [I 490-I 492]. Aunque expuestos de modo distinto, los célebres argumentos de Sócrates en el Ión platónico apuntan a un fin semejante al de Leonardo: deslindar la poesía de las ciencias, cuyo conocimiento los vanos rapsodos asumían para el poeta y para sí mismos; en el epítome de Ficino: "Omnes artes \& scientias poetæ tradunt, sed omnes didicisse humano studio impossibile est, cum unicam ex parte percipere est difficillimum. Non igitur arte humana, sed diuina quadam infusione proferunt". In Platonis Ionem, uel de furore poetico, ad Laurentium Medicem uirum magnanimum Epitome, en Ficino, Opera, I283. Véase por su parte el "universalismo" ingenuo defendido por Cellini en su carta a Varchi, sobre que el escultor requiere ser soldado, orador o músico para correctamente representarlos. Benedetto Varchi, "Della maggioranza e nobiltà dell'arti”, 8I. Claro está, Sócrates también refutó las pretensiones de conocimiento general de los "artesanos" (cheirotéchnai /demiourgoí: Apologia Socratis 22d; en Opera, ed. I. Burnet).

I20. Tò tês psychês ómma (Respublica 533d2); o bien Oracula chaldaica I, 8-9 (ed. E. de Places [París: Les Belles Lettres, I97I]. Transmitido en la Edad Media, como en el tratado atribuido a Alcher de Clairvaux: "Dicitur spiritus mens rationalis, ubi est quaedam scintilla tanquam oculus animae, ad quem pertinet imago et cognitio Dei” (X). De spiritu et anima, vol. 40 de Patrologia Latina, col. 785. En el Renacimiento: "Animæ oculus mens est" (Lectiones antiquae II, XXXII): Ludovicus Caelius Rhodiginus, Lectionum antiquarum libri triginta. Recogniti ab Auctore, atque ita locupletati, ut tertia plus parte auctiores sint redditi (Fráncfort del Meno: Heredes Andreæ Wecheli, Claudium Marnium \& Ioannem Aubrium, I599), col. 85D; "i nostri occhi de la mente", "gl'occhi de l'Anima, o de l'intelletto" (Dialoghi d'amore, III): Leone Ebreo, Dialoghi d'amore. Hebreische Gedichte, ed. Carl Gebhardt (Heidelberg/ Londres/París/Ámsterdam: Carl Winters Universitätsbuchandlung/Oxford University/Les Presses Universitaires/Menno Hertzberger, Curis Societatis Spinozanae, I929), I4r y I07v; o bien, Hamlet ve — anticipo del espectro- a su padre muerto "In my mind's eye" (I, II, I84). Palomino no dejará de consignar: "El entendimiento, que es la principalísima parte del hombre, se denomina con la frase de los ojos. La mayor felicidad de nuestra naturaleza, consiste en el acto de la visión beatífica”, Palomino, El museo pictórico I, I, viII, \$ IV, I I 4a-b. 
las imágenes; ${ }^{\text {I2I }}$ la phantasía, pese a lo sugerido por la etimología aristotélica (De anima 429a3-4: "y el nombre lo ha tomado de 'luz', porque sin luz no es posible mirar"), ${ }^{\text {I22 }}$ mira entre sombras; la suya es una "luz tenebrosa".

Aunque pudiera leerse como una continuación de los denuestos filosóficoteológicos contra la phantasía, Leonardo camina en sentido contrario al de esas viejas concepciones que reescribe con espíritu crítico. La imagen anímica resulta —en oposición a lo enseñado por la mística cristiana de san Agustín ${ }^{\text {I23 }}$ o del citado Hugo de San Víctor ${ }^{124}$ o, con posterioridad, la del hermetismo de Bruno y su "espejo vidente" del alma - inferior a la sensible, en tanto que el centro de gravedad del proceso epistemológico ha sido invertido por Leonardo de lo interior a lo exterior. Para Hugo de San Víctor y la tradición idealista, la verdadera lux es la racional o espiritual; en contrapartida, en este apunte de Leonardo, sin el ojo sensible, el alma queda reducida a la visión fantasmal

I2I. Por ejemplo, en el siglo XVII se representa al oculus imaginationis en una conocida ilustración (I, II, III: “De animæ memorativæ scientia, quæ vulgo ars memoriæ vocatur”) del Ars memoriae de Robert Fludd, Tomus secundus De supernaturali, naturali, preternaturali et contranaturali Microcosmi historia, in Tractatus tres distributa: Authore Roberto Flud alias de Fluctibus Armigero \& Medicine Doctore Oxoniensi (Oppenheim: Impensis Iohannis Theodorj de Brÿ, I6I9), 47. Más tarde, Vico indicará que "phantasia [...] est ingenii oculus, ut judicium est oculus intellectus". Giambattista Vico, De antiquissima italorum sapientia, ed. Manuela Sanna (Roma: Storia e Letteratura, 2005), I34. En la época romántica, Joubert atribuirá también a la imaginación la misma figura: "L'imagination est l'œil de l'âme" (Pensées III, XLVII). Joseph Joubert, Pensées, maximes, essais et correspondance de J. Joubert, ed. M. Paul Raynal, vol. I (París: Librairie Académique Didier et $C^{\mathrm{e}}$, I86I), I58.

I22. La etimología de la voz responde a phantázestai / phainesthai, pero, en última instancia, éstos convergen con pháos en el radical indoeuropeo *bh(e) 2-, "alumbrar", "iluminar" (también "explicar", "hablar"). Véase Pierre Chantraine, Dictionnaire étymologique de la langue grecque. Histoire de mots (Avec un Supplément, de Alain Blanc, Charles de Lamberterie et al.) (París: Klincksieck, I999), I I68b-i I72a (s.v. pháe y phaino); y Alessandra Manieri, L'immagine poetica nella teoria degli antichi. "Phantasia" ed "enargeia", Filologia e Critica 82

(Pisa y Roma: Istituti Editoriali e Poligrafici Internazionali, I998), I7-I8.

I23. "melior est tamen imaginatio corporis in animo quam illa species corporis in quantum haec in meliore natura est, id est in substantia uitali sicuti est animus" (IX, XI, IO-I3 IX, XI, IO-I3). De trinitate, vol. 50 de Corpus Christianorum Series Latina, ed. W. J. Mountain (Turnhout: Brepols, I967), 307.

I24. La imagen pasa desde el sentido a la imaginación que es una "parte más pura" (como lo es en mayor grado la razón): "Ergo imaginatio nihil aliud est quam similitudo corporis, per sensus quidem corporeos ex corporum contactu concepta extrinsecus, atque per eosdem sensus introrsum ad partem puriorem corporei spiritus reducta, eique impressa”. De unione corporis et spiritus, vol. I77 de Patrologia Latina, col. 288A. 
del "ojo tenebroso" (que despliega mejor su poder, en todo caso, durante el sueño). ${ }^{\text {I25 }}$ Por ello, su sentido es en este punto más próximo al del empirismo del XVII, como el de Hobbes y su visión de imagination a modo de "decaying sense", ${ }^{126}$ o bien, lo observado luego por Wolff sobre que "phantasmata minus clara sunt ideis sensualibus"I27 (I, I, 9I; "las imágenes son menos claras que las formas sensibles"), donde "ideas" corresponde — como en Leonardo- a la presentación material de las cosas. Así, la poesía es “inferior” a la pintura por ser menos visual y más imaginaria, menos comprometida con la experiencia sensoria, lo que en un contexto más amplio la ubica en la disputa general del pintor contra los scrittori, basados en "signos" antes que en las "cosas" y que sustentan en muchos casos un saber "ilusorio" de la realidad. ${ }^{\mathrm{I} 2}$ No se

I25. "Perchè vede più certa la cosa l'occhio ne' sogni, che colla immaginazione stando desto”. Da Vinci, Codex Arundel, 278v, en Da Vinci, Scritti scelti, 6r i. Según explicaba Avicena (Le Livre de science, 82): "si l'âme est vigoureuse ou si l'imagination trouve l'occasion d'un repos, celle-ci, demeurant libérée du mouvement, se pare de l'éclat des substances spirituelles: si ces substances ne resplendissent pas dans l'âme, c'est parce que l'âme n'en est pas susceptible, étant occupée de choses inférieures". Si el “ojo tenebroso" ve por la intrínseca condición lumínica del spiritus (Kilwardby, De spiritu fantastico, I07: "spiritus uiuificans lumen quoddam est, et ipse spiritus uiuificatus luminosus est”, q. 3, 212), los teólogos podían explicar la mayor claridad de la visión onírica por la mayor cercanía del alma durante el sueño respecto de la luz primaria emitida por el "sol inteligible".

I26. "IMAGINATION therefore is nothing but decaying sense, and is found in men and many other living creatures [...] The decay of sense in men waking is not the decay of the motion made in sense, but an obscuring of it, in such manner as the light of the sun obscureth the light of the stars [...] And any object being removed from our eyes, though the impression it made in us remain, yet other objects more present succeeding and working on us, the imagination of the past is obscured and made weak, as the voice of a man is in the noise of the day" (I, II, 2-3). Thomas Hobbes, Leviathan. With Selected Variants from the Latin Edition of I668, ed. Edwin Curley (Indianapolis y Cambridge: Hackett, I994), 8.

I27. "Quoniam itaque praterea phantasmata minus clara sunt ideis sensualibus (\$. 96. Psych. empir.) \&, ne ab his obscurentur (\$. 99. Psych. empir.), attentio quantum fieri potest ab iisdem sit avertenda, ut animæ quasi sola præsentia sint phantasmata (\$. 257. Psych. empir.), ac ideo clariora evadant (\$. Ior. Psych. empir.); facile patet, nos super visibilibus facilius reflectere posse, præsertim si quæ in iis diversa sunt in oculos statim incurrant, quam super phantasmatis". Christian Wolff, Philosophia Moralis siue Ethica (Halle, Sajonia-Anhalt: In officina libraria Rengeriana, I750), I24.

I28. En general, de aquellos "especuladores" que basan su saber más en la "imaginación” que en la experiencia: "sì che voi, speculatori, non vi fidate delli altori che hanno sol colla imaginazione voluto farsi interpetri fra la natura e l'omo, ma sol di quelli che non coi cenni della natura, ma cogli effetti delle sue esperienze hanno esercitati i loro ingegni”. Codex I [París: Institut de France, Ms. I (2180)] IO2 (54) r y Ior (53) v, en Da Vinci, Scritti scelti, 
olvide que los dichos anteriores ("sofismas [...] de un hombre ingenioso") I29 han sido al menos en parte apurados por el propio contexto polémico del paragone (quizá, como se ha supuesto, frente a algún concreto oponente en la corte de los Sforza), donde se recurren a todas las conjeturadas debilidades de la adversaria para anotarse una victoria argumentativa.

\section{La dimensión ideal de la phantasía artística y la orientación filosófica de Leonardo}

Notorio y reiterado es el énfasis "empírico" de la teoría leonardesca; pero hay que tomar en cuenta otros apuntes de interés que iluminan la cuestión de modo distinto y complementario. ${ }^{130}$ En un texto anterior a los precitados se lee: "La idea, o bien imaginativa, es timón y rienda de los sentidos, porque la cosa imaginada mueve el sentido". ${ }^{13 \mathrm{I}}$ En este caso, la imaginativa es en efecto "timón"I32 y "rienda" de los sentidos, pero también, para éstos, potencia

276. Argumento semejante en su conocida autoapología como "omo sanza lettere", donde se encarece el saber fruto de la "sperienzia", y no de las palabras de otros, como la propia "maestra di chi bene scrisse". Da Vinci, "Fogli d'anatomia e di ottica" (I489-90), Codex Atlanticus, 204v a, en Scritti scelti, 70-171. También la irónica mención que se incluye en sus textos anatómicos, centrados en las evidencias de la realidad natural: "e il resto della difinizione dell'anima lascio ne le menti de' frati, padri de' popoli, li quali per ispirazione san tutti li segreti”. Da Vinci, "Fogli d'anatomia posteriori al I500", Codex Windsor, RL I9I I5, en Da Vinci, Scritti scelti, 503; y The Literary Works, ed. Richter, $\$ 837$.

I29. Schlosser, Die Kunstliteratur, I54.

130. El primado del sensus visualis y sus problemas comprensores y de representación desplazan a la phantasía como "libre re-creación" interior en los textos de Leonardo; por ello no es extraño el énfasis de Croce, aunque resulte excesivo y discutible a la luz de otras de sus reflexiones: "Non si può dire, per altro, che Leonardo avesse vivace coscienza intellettuale dell'attività creatrice dell'artista, della interiorità che si concreta nell'opera, della fantasia che è la vera genitrice dell'arte". Croce, "Leonardo filosofo", en Leonardo da Vinci, 24I.

I3I. "La idea, over imaginativa, è timone e briglia de' sensi, imperò che la cosa imaginata move il senso". Da Vinci, Codex Windsor, RL 19019, en Da Vinci, Scritti scelti, I56.

I32. La misma imagen usará Robert Burton: "So that I may certainly conclude this strong conceit or imagination is astrum hominis, and the rudder of this our ship" (I, II, III, II). Robert Burton, The Anatomy of Melancholy [The First Partition], ed. Holbrook Jackson (Nueva York: New York Review Books, 200I), 257. Siglos más tarde, Keats desarrollará la imagen en una pequeña alegoría náutica de la poesía: "a long Poem is a test of Invention which I take to be the Polar Star of Poetry, as Fancy is the Sails, and Imagination the Rudder." John Keats to Benjamin Bailey, 8 october I8I7, en Selected Letters, ed. Grant F. Scott (Cambridge: 
"motora"; igualmente, la pintura es "ciencia", es cognición interior y sus creaciones interiores determinan su plasmación material. De singular interés es la llamativa identidad entre idea e imaginativa, propuesta en términos, no del objeto o "forma" de la representación, sino de la propia facultad (la imaginativa) o el "lugar interior" de estos procesos con el valor semántico de "mente" (según confirma la expresión correlata: "en la mente, o bien la imaginativa" / "nella mente, overo immaginativa"), ${ }^{\mathrm{I} 33}$ lo que sin duda implica un uso anómalo de la voz sin huellas rastreables en la tradición precedente; ${ }^{\mathrm{I} 34}$ quizá lo propició la condición "senza lettere" ("sin letras") del autor, pero resulta una curiosa "evolución léxica” que conservaría cierta lógica operativa a la luz de la palabra phantasía (en efecto, la propia immaginazione tenía de antiguo el significado doble adquirido por aquélla: el de contenido antes que el de la capacidad de la representación, o, si se quiere, la unidad prediferenciada de ambos). El helenismo, tan gustado posteriormente en la literatura artística del Renacimiento — asimismo usado, como sugiere Vasari, como un interior locus: "nella idea"-, ${ }^{\mathrm{I}} 35$ aparece en otros apuntes: “¿Qué poeta con palabras te pondrá delante, oh amante, la verdadera efigie de tu idea con tanta verdad como hará el pintor?"; 136 "Y si tu escribieras la figura de algunos dioses, no tendrá esa escritura la misma veneración que la idea pintada”. ${ }^{37}$

Como puede verse, en estos últimos ejemplos - y en mayor medida que en el anteriormente citado-, tal "idea" tiene un sentido, si bien no ajeno a la

Massachusetts, Harvard University Press, 2002), 42.

133. Da Vinci, Libro di Pittura, $\$$ I5, I39 [ca. I500-1505].

I34. Es sin duda peculiar este corrimiento significativo de la idea para nombrar una facultad anímica, pero no insólito para ciertas adecuaciones de la lengua; por ejemplo, en el semejante desplazamiento semántico que ejerce una metonimia de Dante que emplea immagine por immaginazione (effectus pro causa): "Io non posso fuggir ch'ella non vegna / ne l'imagine mia, /se non come il pensier che la vi mena." Dante Alighieri, Rime LIII, I6-I8, en Rime, ed. Gianfranco Contini (Turín: Einaudi, I965), 207.

I35. Por ejemplo "e se lo metteva talmente nella idea, che poi arrivato a casa lo disegnava come se l'avesse avuto presente". Vasari, Le Vite, 26.

136. "Qual poeta con parole ti metterà inanzi, o amante, la vera effigie della tua iddea con tanta verità qual farà il pittore?" Da Vinci, Libro di Pittura, $\$$ I8, I 42 [ca. I 490-I 492].

137. "E se tu scriverai la figura d'alcuni dèi, non sarà tale scrittura nella medesima venerazione che la iddea dipinta". Da Vinci, Libro di Pittura, \$25, I50 [ca. I500]. Antes, en otro ejemplo de las imágenes sagradas, encarece la veneración que el pueblo les rinde, "non altramente che se tale iddea fusse lì presente in vita". Da Vinci, Libro di Pittura, $\$ 8$, I35 [ca. I500-1505]. Cabe mencionar que los usos de la palabra en Leonardo no fueron considerados en la célebre Idea de Panofsky. 
vOz griega en tanto que species corporis, abiertamente antiplatónico al referir lo sensible, la re-presentación puesta ante los ojos y no aquello que, por definición, transciende a la materia. ${ }^{138}$ Baste contrastar esto con la célebre negativa de Plotino, referida por Porfirio, a ser retratado, por reproducir el cuerpo, es decir, hacer la "imagen de una imagen" (Vita Plotinis I, 8); pues, en efecto, aquello que el pintor Carterio puede captar y retener — mirando al filósofo en su clase para después pintarlo de memoria - son sólo las particularidades de su apariencia externa (phantasiai). ${ }^{139}$ Por el contrario, para Leonardo la idea vale como una phantasía "directamente aprehendida" (epibletikôs) por la vista o la mente, que, a semejanza de la enseñanza epicúrea, "es la forma misma de la cosa sólida" (Epistula ad Herodotum 50, 6; ed. G. Arrighetti) con certidumbre cognoscitiva fincada en la propia materialidad, puesto que "la fantasía, a la que llama [Epicuro] también enárgeia, dice que es siempre verdadera" (Adversus mathematicos VII [Adversus dogmaticos I], 203; ed. H. Mutschmann). ${ }^{\mathrm{I} 0}$ En todo caso, hay que subrayar que el uso leonardesco resulta prefigurador de la "materialización" de la idea que dominará en el pensamiento moderno, como mostrarán de modo inequívoco los filósofos más de un siglo después (Leonardo habría aprobado las referencias "a las ideas que son recibidas del sentido común": "ideas à sensu communi accipiendas"). ${ }^{\text {I I I }}$

Sin embargo, el vigoroso énfasis en la fenomenicidad de la teoría estética leonardesca no debe ocultar su visión epistemológica general implicada en la labor artística. Es notorio que la primacía de lo visible es destacada en torno

I38. Luego, no será en lo más mínimo anómalo afirmar que el “intelecto imagina” en sus indagaciones matemático-geométricas: "quanto lo intelletto possa immaginare”. Da Vinci, Codex Windsor, RL I2280r, en Da Vinci, Scritti scelti, 39I; y The Literary Works, ed. Richter, $\$$ I475.

I39. El retrato en efecto "is a symbol of the illusory world of sense above which Platonism strives to raise the soul”, y puede ser entendido también como un símbolo metatextual de la propia biografía de Porfirio. M. J. Edwards, "A Portrait of Plotinus", The Classical Quarterly (Óxford) 43, núm. 2 (I993): 48I.

I 40. Recuérdese también, sobre esta doctrina epicúrea: "Nisi autem rerum natura perspecta erit, nullo modo poterimus sensuum iudicia defendere. Quicquid porro animo cernimus, id omne oritur a sensibus; qui si omnes veri erunt, ut Epicuri ratio docet, tum denique poterit aliquid cognosci et percipi. Quos qui tollunt et nihil posse percipi dicunt, ii remotis sensibus ne id ipsum quidem expedire possunt quod disserunt." Cicerón, De finibus I, 64; ed. J. Martha (París: Les Belles Lettres, 1967).

I4I. René Descartes, Regule ad directionem ingenii XII, en Euvres de Descartes, vol. Io, 4I5. Aun: para Descartes las "ideas" interiorizadas en la phantasía son materialmente extensas; el viejo símil del sello y la cera es mucho más que una mera analogía. Véase Euvres de Descartes, vol. Io, 4I2. 
a la recepción del arte, donde las ventajas del ojo corporal se imponen sobre el ojo de la phantasía como medio por el que la obra puede ser conocida; sin embargo, esto no determina necesariamente su "creación". La posición del pintor frente a la realidad natural no es la de un mero reproductor; también se contempla la condición de "rivalidad", de aemulatio de su inagotable belleza: "El pintor disputa y rivaliza con la naturaleza". ${ }^{42}$ La pintura abraza lo natural y más, "no sólo atiende a las obras de la naturaleza, sino a infinitas que la naturaleza jamás creó"; ${ }^{43}$ las obras de las artes humanas, fruto de la vista, son superiores a la naturaleza por su infinitud: "y en esto supera a la naturaleza, porque los singulares naturales son finitos, y las obras que el ojo manda a las manos son infinitas, como lo demuestra el pintor en sus ficciones de infinitas formas de animales, hierbas, plantas y lugares". ${ }^{44}$ Esto se basa en una constitutiva dualidad cognoscitiva y práxica; el propio ejemplo de Masaccio deja en claro que sólo el conocimiento permite acceder a una esfera superior para el arte. La de Leonardo es una sabia mímesis, un obrar que es saber, donde la práctica tiene que aliarse necesariamente con la teoría; ésta debe ser guía en su periplo creativo (que es, como la "idea" o "imaginativa”, timón y brújula ${ }^{\mathrm{I} 45}$ del pintor) supeditándose el pintar a lo en ella dispuesto, para poder plasmar "con forma demostrativa al ojo la intención y la invención hecha primero en tu imaginativa” ${ }^{146}$ Incluso con vistas a la propia elaboración material del cua-

I42. "Il dipintore disputa e gareggia colla natura". Da Vinci, Codex Forster III [Londres: South Kensington Museum], 44V, en Da Vinci, Scritti scelti, 238; y The Literary Works, ed. Richter, $\$ 662$.

I43. "non ch'alle opere di natura, ma ad infinite attende che la natura mai le creò". Da Vinci, Libro di Pittura, \$27, I52 [ca. I490-I 492].

I 44. "et in questo supera la natura, perché li semplici naturali so' finiti, e l'opere che l'occhio comanda alle mani sono infinite, come dimostra 'l pittore nelle finzioni d'infinite forme d'animali et erbe e pianti e siti". Da Vinci, Libro di Pittura, \$28, I52 [ca. I50o]. En este asunto puede vislumbrarse un cierto antagonismo entre el Leonardo artista y el científico; pues, cuando este último habla, no deja de señalar por el contrario los límites de las invenciones del ingegno humano frente a las de la naturaleza, ya que no puede hallarse "invenzione più bella nè più facile nè più brieve della natura, perchè nelle sue invenzioni nulla manca e nulla è superfluo". Da Vinci, "Fogli d'anatomia posteriori al I500", Codex Windsor, RL I9I I5, en Da Vinci, Scritti scelti, 503; y The Literary Works, ed. Richter, $\$ 837$.

I45. Da Vinci, Codex G [París: Institut de France, Ms. G (2I78)], 8r, en Da Vinci, Scritti scelti, 42I; The Literary Works, ed. Richter, \$I9; y Da Vinci, Libro di Pittura, \$ 80, I84 [ca. I5IO-ISII].

I 46. "con dimostrativa forma a l'occhio la intenzione e la invenzione fatta in prima nella tua imaginativa”. Da Vinci, Libro di Pittura, $\$ 76$, I82 [ca. I 492]. Este operar a partir de la imaginativa 
dro, la maestría no es "mecánica" sino "mental”; hacia ello apunta un dicho de Leonardo escuchado por Fernández de Oviedo: "Porques más seguro de quitar los errores de la mente que [...] los detalles donde se han pintado”. ${ }^{4} 7 \mathrm{De}$ modo semejante, los pintores auténticos utilizan sólo sucedáneamente apoyaturas como el prospectógrafo, puesto "que saben 'hacer de fantasía' siguiendo los efectos de la naturaleza". ${ }^{48}$ En este sentido, Leonardo acaso no objetaría del todo el parecer — en parte derivado de su pensamiento- de su traductor Fréart de Chambray, para quien la pintura es "toda espiritual", "toda espíritu" I49 y, por tanto, apta sobre todo para "el ojo del entendimiento". ${ }^{550}$

Además, en el pensamiento leonardesco es notoria la confluencia en la pintura de un arte y una ciencia "universales", con una vocación totalizadora en sus pretensiones comprensoras y representativas. Prima entonces la concepción de la pintura como imitadora de la naturaleza en cuanto conlle-

demanda siempre la consideración "dalla ragione e dalli effetti naturali". Manzi entendía el pasaje como muestra de que Leonardo "inculca il non operare di maniera", que vale por "operare di fantasia e di memoria". Da Vinci, vol. I, Trattato della Pittura (1817), 502-503, n. I5.

I47. Comunicándole al cronista madrileño algunos de los requisitos necesarios al pintor: "e que demás de ser [tres o cuatro palabras ilegibles] bien leýdo e amigo de la sçiençia, porque lo [una palabra ilegible] sea grato a los que entienden. Porques más seguro de quitar los errores de la mente que [una o dos palabras ilegibles] los detalles donde se han pintado." De D. Fadrique II Enríquez, Almirante de Castilla [Batalla II, Quinquagena. I, Diálogo 5], en Gonzalo Fernández de Oviedo, Batallas y quinquagenas, ed. Juan Bautista Avalle-Arce, Serie de Lengua y Literatura 4 (Salamanca: Diputación de Salamanca, 1989), I06 [276v]. Frente a esta lectura conservadora de Avalle-Arce, Pedretti ("Introduzione", en Da Vinci, Libro di Pittura, $\$$ 5I) presenta — sin comentar ninguna dificultad textológica - el pasaje del códice salmanticense (ms. 359) del siguiente modo: "y que, demás de ser un buen iumétrico, sea ombre bien leydo y amigo de sciencia por lo que pintare sea grato a los que entienden. Porque más seguro es pintar los errores de la mente que cancelar los de la obra donde se han pintado". Por lo que atañe a la frase citada, la propuesta de Pedretti ("pintar" en vez de "quitar", etendiendo así: "perché è più facile dipingere gli errori della mente che correggerli nell'opera dipinta"), redunda, al menos, en una obviedad, cuando no en un sinsentido ("seguro" como lo "libre de daño" y "sin riesgo": est securius...); más llano y lógico parece lo deducible aun en el texto trunco de Avalle-Arce (i.e. mejor corregir en la mente y no en el cuadro).

I48. "che sanno fare di fantasia apresso alli effetti di natura". Da Vinci, Libro di Pittura, $\$ 39,164[$ ca. I500-I505].

149. Roland Fréart de Chambray, Idée de la perfection de la peinture; en Parallèle de l'architecture antique avec la moderne, suivi de Idée de la perfection de la peinture, eds. Frédérique Lemerle-Pauwels y Milovan Stanić (París: École Nationale Supérieure des Beaux-Arts, 2005), 201 y 257.

I50. Fréart de Chambray, Idée de la perfection de la peinture, 200. 
va la comprensión de sus formas: "Si despreciaras a la pintura, que es única imitadora de todas las obras visibles de la naturaleza, por cierto despreciarás una sutil invención, que con filosófica y sutil especulación considera todas las

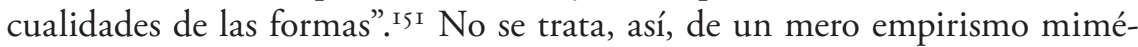
tico ("La naturaleza está llena de infinitas razones, que no fueron jamás en la experiencia"; ${ }^{52}$ "Ningún efecto hay en la naturaleza sin razón; entiende la razón y no te hace falta experiencia”), ${ }^{153}$ sino de su meditada apropiación para la conciencia. El arte es conocimiento y como tal se encuentra en la propia interioridad; luego, el objetivo supremo de la comprensión es la del propio operar del hombre: "Oh especulador de las cosas, no te elogies por conocer las cosas que ordinariamente la naturaleza por sí misma dirige, sino alégrate de conocer los fines de aquellas cosas que son diseñadas de tu mente". ${ }^{154}$ Ése es el meollo de la teoría, que indaga no sólo lo exterior, sino la propia teleología de su despliegue autoconsciente. Esto ciertamente incluye a la sottile invenzione del pintor —es decir, de su phantasía_, "la cual con filosófica y sutil especulación considera todas las cualidades de las formas"; ${ }^{155}$ es así que, para Leonardo, se revela como auténticamente filosófica ("la pintura es filosofía"). ${ }^{56}$ La phantasía del artista es, o debe ser, no sólo especular, sino también especulativa; ${ }^{157}$ su condición mimética es lo espiritual ilimitado $\mathrm{y}$,

I5I. "Se tu isplezzerai la pittura, la quale è sola imitatrice di tutte l'opere evidenti di natura, per certo tu sprezzerai una sottile invenzione, la quale con filosofica e sottile speculazione considera tutte le qualità delle forme". Da Vinci, Codex Atlanticus, Ioor, en Da Vinci, Scritti scelti, 205-206; y The Literary Works, ed. Richter, $\$ 652$.

I52. "La natura è piena d'infinite ragioni, che non furon mai in isperienzia”. Da Vinci, "Considerazioni, motti, massime”, Codex I, I8r, en Da Vinci, Scritti scelti, 6r 2.

I53. "Nessuno effetto è in natura sanza ragione; intendi la ragione e non ti bisogna sperienza”. Da Vinci, Codex Atlanticus, I47v a, en Da Vinci, Scritti scelti, 6r 2.

I54. "O speculatore delle cose, non ti laldare di conoscere le cose che ordinariamente per sè medesima la natura conduce, ma rallegrati di conoscere il fine di quelle cose che son disegnate dalla mente tua”. Da Vinci, Codex G, 47r, en Da Vinci, Scritti scelti, 6r7.

I55. "la quale con filosofica e sottile speculazione considera tutte le qualità delle forme". Da Vinci, Codex Atlanticus, Ioor, en Da Vinci, Scritti scelti, 206.

156. Da Vinci, Libro di Pittura, \$9, I36 [ca. I500-I505].

I57. En términos generales, hay en Leonardo una unidad epistemológica del arte y la ciencia para la que prácticamente no se concibe separación: son dos caras de la misma medalla de la inteligencia. Cabe aquí recordar la sugerente cita que Cassirer atribuye al propio Leonardo y que ofrecía como una muestra de la doble validación cognoscitiva del arte y la ciencia — confrontándola con el restrictivo apunte de Alberti sobre el necio artista que se fía de su ingenium - : "la scienza è una seconda creazione fatta col discorso, la pintura è una seconda 
presionada por su universalidad, "la mente del pintor" se ve impelida "a transmutarse en la propia mente de la naturaleza"; ${ }^{158}$ esto le confiere una auténtica condición divina: "La divinidad que tiene la ciencia del pintor hace que la mente del pintor se transmute en una semejanza de la mente divina". ${ }^{59}$

creazione fatta colla fantasia". Véase Cassirer, Individuum und Kosmos, I70. Pero, como ya ha apuntado Panofsky, "Artist, Scientist, Genius”, en Leonard's Writings, ed. Farago, 7I-72, n. 52, este texto es un "fantasma" no localizable en los textos leonardescos, y parece hacerse eco de una paráfrasis moderna. A Panofsky le parecía "sospechoso" no sólo por la voz creazione — “continuamente evitada" por Leonardo_-, sino incluso por fantasia, aunque de esta palabra hay notorias apariciones en sus textos; sin embargo (aunque sin mayores implicaciones de orden "teológico"): "la pittura non more mediante la sua creazione come fa la musica"; "la scienzia [...] sempre è testimonia e tromba del suo creatore, perché ella è figliola di chi la genera". Da Vinci, Libro di Pittura, \$ 65, I75-I76 [ca. I505-I5Io]. Kemp ("From 'Mimesis' to "Fantasia", 38I-382) ha registrado varias incidencias más de creare en Leonardo, junto con otros verbos semejantes sobre la producción artística: partorire, nascere, generare, vinculados con la generación natural. Cabe notar la paulatina apropiación nominal e incluso —al menos en parte- conceptual del término creatio (circunscrito por la teología a la "productio ex nihilo" divina) para el "creador artístico", que se vio facilitada en el horizonte renacentista por la recuperación etimológica de la voz griega poietés; tal y como explicaba ya Landino: "Quapropter ex eo verbo quod apud illos est poieîn, poietèn Graeci deduxerunt. Poiéo autem modo ex aliquo quicquam facere significat, modo ex nihilo creare, ut en archêi epoíesen ho theòs tòn ouranòn kaì tèn gên". Cristoforo Landino, Scritti critici e teorici, ed. Roberto Cardini, vol. I (Roma: Bulzoni, I974), 228. Esto aparecerá asimilado y desarrollado en la poética de Scaliger, quien asimismo debió probablemente respaldar algunas de las expresiones sobre la "creación” artística tanto en Lomazzo y Zuccaro como en teóricos de poesía del medio inglés. Por su parte, la idea del "poeta inspirado" — asumida en la Edad Media por autores como Alain de Lille, Dante o Chaucer-, fue ya retomada en las teorías poéticas por los tempranos De poetice ad Laurentium Medicem libri III, ed. Trinkaus (ca. I490-I 492), de Bartolommeo della Fonte: "Ac primum omnium divinam rem esse poeticem, divinosque poetas et caelesti afflatos numine esse arbitror" (3v-4r); en Charles Trinkaus, "The Unknow Quattrocento Poetics of Bartolomeo della Fonte", Studies in the Renaissance I3 (1966): 97. Italia es el punto de partida de las disputas modernas sobre el furor inspirado platónico y la melancholia aristotélica (Problemata XXX, I; 953a) y de la tradición médica, ya entremezcladas en las enseńanzas de Ficino (véase "De studiosorum sanitate tuenda", De vita I, v, en Ficino, Opera, vol. I, 497) que abren las amplias polémicas sobre el posible origen metafísico / físico del pensamiento "genial" y sus estados anímicos concomitantes a ser desarrolladas por autores como Barbaro el Joven, Nifo, Pomponazzi, Bruno, Campanella, etcétera.

I58. "a trasmutarsi nella propria mente di natura”. Da Vinci, Libro di Pittura, $\$ 40,164$ [ca. I500-1505].

I59. "La deità ch'ha la scienzia del pittore fa che la mente del pittore si trasmuta in una similitudine di mente divina”. Da Vinci, Libro di Pittura, \$ 68, I78 [ca. I490-I 492]. 
Quizá no sea una mera coincidencia enunciativa el que la pintura, en tanto que "es continente de todas las formas que son", ${ }^{160}$ de las obras humanas y divinas, ${ }^{16 \mathrm{I}}$ parezca adoptar para sí misma el concepto de cuño platónico sobre el noûs o las almas privilegiadas que han visto la fuente inteligible: "las almas que allí han mirado todas las cosas y desde todas surgidas, como conteniendo todas en sí mismas de principio a fin" (Enneades V, 8, I0, I8-20); la immaginazione pictórica se reviste, en tal caso, de auténticas pretensiones demiúrgicas ${ }^{162}$ que marcan un paso adelante en el Renacimiento en la imagen "divina" del artista. Se trata, sin embargo, de repentinas semejanzas con las doctrinas neoplatónicas (o aun, en un enlace más remoto, con la doctrina estoica y la unidad del ars y el "fuego artífice" del cosmos) cuya procedencia incluso podría radicarse — junto con las claras alusiones u otros paralelismos posibles - en su etapa florentina, pero en buena medida son ilusorias; según dicho ejemplo cabe así juzgarlo, por suponer, en el fondo, la inclusión en el arte de phantasíai y no idéai en un sentido platónico. Lo que importa a Leonardo es — como bien apuntaba Croce — "el conocimiento del fenómeno", ${ }^{163}$ la estructura óptica y óntica de lo "presentado ante los ojos" que constituye para él —frente a la indagación interior del filósofo— "la primera verdad de esos cuerpos, porque el ojo se engaña menos"; ${ }^{64}$ y casi podría asumirse que, antes que el "fenómeno mismo", lo que en verdad interesa a Leonardo es su representación, de manera concreta en este caso, su potencial valor como - para utilizar el término estoico- technikè phantasía, como algo apropiado por la conciencia artística en una "cognición creadora". De modo similar, el énfasis en la matemática, aunque semeje en su formulación a la célebre inscripción de la Academia ("No me lea en mis principios quien no sea matemático" ${ }^{65 /}$

I60. "è contenitrice de tutte le forme che sono". Da Vinci, Libro di Pittura, $₫ 3$ Ib, I54 [ca. I492].

I6I. "Ma la deità della scienzia della pittura considera l'opere così umane come divine". Da

Vinci, Libro di Pittura, $\$ 23$, I48 [ca. I 490-I 492].

162. De acuerdo con Clark: "Leonardo always insists on this godlike quality of the painter's imagination. From the divine element in the science of painting it follows that the mind of the painter is transformed into the likeness of the mind of God". Kenneth Clark, Leonardo da Vinci. An Account of His Development as an Artist (Cambridge: University, I952), 72.

163. Croce, "Leonardo filosofo", en Leonardo da Vinci, 234.

164. "la prima verità di tali corpi, perché l’occhio meno se inganna". Da Vinci, Libro di Pittura, $₫$ IO, I36 [ca. I500-I505].

165. "Non mi legga chi non è matematico nelli mia principi". Da Vinci, Codex Windsor, RL i9i I6r, en Da Vinci, Scritti scelti, 6I4; The Literary Works, ed. Richter, $\$_{3}$. 
"Nadie entre que no sepa geometría"), ${ }^{166}$ tiene el sentido del conocimiento que desentraña la composición presencial de las cosas del mundo, y no la abstracción de éstas camino a lo eterno suprasensible.

Ya Olschki atribuyó la salida de Leonardo de Florencia a sus diferendos con el neoplatonismo, mientras que su estancia milanesa respondería a una mayor afinidad con el aristotelismo asentado en el norte de Italia. ${ }^{167}$ Así, Schlosser apuntó su distancia del platonismo (además del escolasticismo), ${ }^{168}$ Panofsky definió la actitud de Leonardo como anti- o paraplatónica, ${ }^{169} \mathrm{Ba}$ rasch destacó su distinto talante respecto de Ficino, ${ }^{170}$ parecer apoyado también, con razonables argumentos, por Ernesto Grassi. ${ }^{17 \mathrm{I}}$ Luego, dadas algunas semejanzas, podría entonces conjeturarse que su modelo onto-epistemológico general resulta un más o menos lejano heredero de Aristóteles, o bien, estructuralmente más conforme con las lecciones del Liceo (a las que acaso pudo ser introducido en su temprana juventud por Joannes Argyropoulos). ${ }^{172}$ En efecto: decir que "Las cosas mentales que no han pasado por el sentido son vanas", ${ }^{773}$ es una profesión de fe de corte aristotélica; el filósofo enseñó la

I66. Olimpiodoro, Prolegomena 9, I, ed. A. Busse (Berlín: Georg Reimer, I902); Miguel Psellos, Opuscula logica III, 62, ed. J. M. Duffy (Leipzig: B. G. Teubner, I992).

167. Sin embargo, Kemp, Leonardo da Vinci: The Marvellous Works, 7I, matiza tales supuestos.

I68. Schlosser, Die Kunstliteratur, I52.

169. Panofsky, "Artist, Scientist, Genius", en Leonard's Writings, ed. Farago, 37, n. I8.

I70. Moshe Barasch, Theories of Art. From Plato to Winckelmann (Nueva York/Londres: New York University Press, I985), I34-I35.

I7I. Oportunamente, Grassi destaca "la tesis puramente antiplatónica de Leonardo": "La verità sola fu figliola del tempo" (Da Vinci, Codex M [París: Institut de France, Ms. M (2183)], 58v, en Da Vinci, Scritti scelti, I33). Ernesto Grassi, Einführung in philosophische Probleme des Humanismus (Darmstadt: Wissenschaftliche Buchgesellschaft, I986), I37.

I72. Según sugirió ya Ivor Blashka Hart, The Mechanical Investigations of Leonardo da Vinci (Londres: Chapman \& Hall, I925), 40. Joannes Argyropoulos ("Giovanni Agiropulo" [ca. I 4I5-I 487]), helenista que pasó de Constantinopla a Italia a mediados del siglo xv, fue el traductor de Aristóteles al latín más influyente de su tiempo y enseñó en Florencia entre I456 y I 472 .

I73. "Le cose mentali che non son passate per il senso son vane". Da Vinci, Codex Windsor, RL I9070, en Da Vinci, Scritti scelti, 6I3. Recuérdese el célebre dictum tomista: "nihil est in intellectu quod non sit prius in sensu" (Quaestiones disputatae. De veritate [q. 2, art. 3, I9], 206), que pasaría a simbolizar a los empiristas del XVII, por medio del posicionamiento de Leibniz contra Locke: "Nihil est in intellectu, quod non fuerit in sensu, excipe: nisi ipse intellectus" (II, I). Gottfried Wilhelm Leibniz, Nouveaux Essais sur l'entendement humain, en God. Guil. Leibnitii Opera philosophica quae exstant Latina, Gallica, Germanica omnia, ed. 
necesidad de la imagen derivada de los sentidos, el phántasma, como condición primera del pensamiento (De anima, III, 7, 43 Ia I4-I5). A su vez, la manifestación sensible supone la realización de la idea, es decir, de la forma (eîdos) que encarna en la materia y que no puede ser pensada sino desde el objeto; la penetración contemplativa de la mente permite adentrarse en la constitución intrínseca de las cosas. Leonardo entiende que la pintura "es primero en la mente de su especulador, y no puede alcanzar su perfección sin la operación manual". ${ }^{174}$ Así, la forma ("idea, over imaginativa") yace en la mente de los hombres como potencia y tiene por ello un mero carácter "sombrío": "Tanta correlación hay de la imaginación con el efecto como hay de la sombra con el cuerpo sombreado"; ${ }^{175}$ sólo puede ser "en acto" realizándose en la obra, donde el eîdos se asienta efectivamente en el sýnolon, el "compuesto" de lo formal y lo material; la pintura "no existe separadamente" de la obra realizada. ${ }^{176} \mathrm{Sin}$ embargo, la "forma misma" es en realidad "la mente artística" (Metaphysica VII, 9, I034a24; "pues el arte es la forma" / "artificium enim est forma"); por ello permanece en el alma la auténtica "perfección” del arte, su elemento superior, el conocimiento y la capacidad plasmante del "creador", donde "la obra es superada por el juicio". ${ }^{177}$

Joannes Eduardus Erdmann (Berlín: Sumtibus G. Eichleri, I840), 223a. Véase Melanchton (Commentarius De anima, I3or): "Vulgo celebratum dictum est. Nihil est in intellectu, quod non prius fuit in sensu. Quod nisi dextre interpretemur, admodum absurdum fuerit. Nam universales noticiæ, \& dijudicatio, non prius fuerunt in sensu"). Bertrand Russell señalará al respecto: "The dictum 'Nihil est in intellectu quod non fuerit ante in sensu', would unquestionably be true, if for intellect we were to substitute imagination; it is vain, therefore if our actual space be Euclidean, to hope for a power of imagining a non-Euclidean space". An Essay on the Foundations of Geometry, intr. John G. Slater (Londres/Nueva York: Routledge, 1997), 79.

I74. "è prima nella mente del suo speculatore, e non pò pervenire alla sua perfezzione senza la manuale operazione”. Da Vinci, Libro di Pittura, \$33, I57 [ca. I500].

175. "Tal proporzione è dalla immaginazione a l'effetto qual è da l'ombra al corpo ombroso". Da Vinci, Libro di Pittura, \$2, I32 [ca. I500-1505].

176. Lo que primaría en este punto es la realización material que objetiva la obra, en la onticidad de su presencia, como en el modelo general de "lo fabricado" por el hombre, al modo del ejemplo de la casa: "pues en algunas cosas es evidente que no es separable la forma, como de una casa" (Metaphysica XI, 2, I060b27-28). Otra cosa es, sin embargo, la relación ontológica de la pintura y la escultura como representación, tanto de lo re-producido respecto del ente "ante los ojos" como de lo "inventado" por la phantasía, tema que apenas y fue meditado por la tradición metafísica occidental.

177. "I'opra è superata dal giudizio". Da Vinci, Libro di Pittura, \$ 57, I72 [ca. I500-I505]. 
Por supuesto, sería un exceso calificar a Leonardo de "peripatético", incluso si se considera una cierta afinidad gnoseológica general respecto del aristotelismo; sobre todo tratándose, claro está, no de un "filósofo de escuela", sino de una poderosa inteligencia dispuesta a dar cauce, con la primaria brújula de la propia experiencia personal, a su avidez por rerum cognoscere causas y su inclinación "innovadora" (como ya lo sugiere un apunte de su amigo Pacioli, al destacarlo entre aquellos "perspicasísimos arquitectos e ingenieros y asiduos inventores de cosas nuevas"). ${ }^{178}$ Leonardo es, en todo caso, menos un homo speculativus que un homo ingeniosus, no un teórico que busca leyes universales, sino una inteligencia vertida a lo particular, a los entes individuales en el hic et nunc; la "universalidad" de la mente está en su potencia especular para reflejar la varietà (sin atarse a un solo canon estético); ${ }^{179} \mathrm{y}$, por ello, es mucho menos un aristotélico-escolástico (o un "neoaristotélico") que un pensador imbuido por un espíritu afín al Humanismo. ${ }^{180}$ A la manera de éste, y a su muy especial forma, los límites del sistema medieval de pensamiento le son en lo fundamental insatisfactorios y por ello Leonardo es, literalmente, un "trans-

I78. "perspicacissimi architecti e ingegnieri e di cose noue assidui inuentori"; al hablar sobre el "scientifico duello" de la legendaria "Accademia Vinciana”, en Milán, bajo el patronazgo ducal de Ludovico il Moro. Luca Pacioli, Divina Proportione. Die Lehre vom goldenen Schnitt. Nach der venezianischen Ausgabe vom Jahre I509, ed. Constantin Winterberg (Viena: Carl Graeser, I889), 33.

I79. "Il pittore debbe cercare d'essere universale, perchè manca assai di degnità a fare una cosa bene e l'altra male, come molti che solo studiano nello ignudo misurato e proporzionato, e non ricercan la sua varietà; perchè e' pò uno omo essere proporzionato e essere grosso e corto, o lungo e sottile, o mediocre; e chi di questa varietà non tiene conto, fa sempre le figure sue in istampa, che pare essere tutti fratelli, la qual cosa merita grande riprensione”. Da Vinci, Codex G, 5v, en Da Vinci, Scritti scelti, 42I; The Literary Works, ed. Richter, \$503; y Da Vinci, Libro di Pittura, $\$ 78$, I83 [ca. I5IO-I5II]. Bien destacaba Blunt que Leonardo "is primarily interested not in the beautiful but in the individual and characteristic". Anthony Blunt, Artistic Theory in Italy. I450-I600 (Oxford University Press, I994), 3 I.

I80. A pesar de su abierta disputa con los litterati, que en él son más bien los representantes del saber libresco medieval. Son agudas las observaciones de Ernesto Grassi al respecto de esta afinidad entre Leonardo y su visión de la "experiencia" (Erfahrung) como base del saber y la órbita del ingenium humanista; véase Grassi, Einführung in philosophische Probleme, I34-I37. Bien recuerda a este propósito el encomio leonardesco sobre "li omini inventori, enterpetri tra la natura e gli uomini” (Da Vinci, Codex Atlanticus, i 7 r b, en Da Vinci, Scritti scelti, I7I) que, en tanto que interpretes et inventores, se revisten con un valor semejante al de los filólogos (en la concepción, operativa sin duda entonces, del Liber mundi); de ello resultaría, según propone Grassi, Einführung in philosophische Probleme, 136, que "Naturwissenschaft, 'scienza', ist Philologie der Natur'. 
gresor”. Nadie quizá como él representa esa “descompartimentación”, de la que ha hablado Panofsky, ${ }^{18 \mathrm{I}}$ de las artes et disciplinae medievales que implica a su vez una transfiguración epistemológica general; la mente del artista espejea una reestructuración de las categorías mismas del conocimiento, que parecen retrotraerse a la posición "original" de un momento refundador, donde la idéa se reviste de la dualidad de eido (ver/conocer), ${ }^{182}$ el ars es aún -o como nunca antes - téchne como saber-hacer (que aspira, de hecho, a confundirse con la epistéme, ${ }^{\mathrm{I} 3}$ con la "physica" o "filosofía natural"), la gnôsis es empeiría (la esperienzia como "madre de toda certeza") ${ }^{184}$ y la "estética" reclama su sustancia vivencial y cognoscitiva como proceso sensible, como aisthesis.

Que la phantasía leonardesca sea ante todo visión, reproductora y plasmante, de las cosas responde a ese momento cimero del naturalismo del Renacimiento en su ávido despertar, tras el milenario ensueño de la fe, y su reconquista fáustica de la realidad. Lo que ahora prima para esta facultad que, como Jano, mira hacia lo sensible y hacia lo espiritual, es la afirmación de sus ojos externos y la recuperación de los misterios de la naturaleza (y donde lo espiritual tiende, por contrapartida, a convertirse en una alteridad para la conciencia). ${ }^{185}$ Así, las vislumbres leonardescas indican a la potencia visual

I8I. Panofsky, "Artist, Scientist, Genius", en Leonard's Writings, ed. Farago, 26-29.

I82. "y los antiguos dicen que el pensar y el percibir son lo mismo" (De anima III, 3, $427 \mathrm{a} 2 \mathrm{I}-22$ ).

I83. El distingo entre scientia y ars no carece de diversas ambigüedades desde el orbe antiguo, extendidas en el horizonte medieval y el renacentista. Por ejemplo, Varchi dará cuenta de un sentido propio y otro "común" del término "arte": "questo nome 'arte' si può pigliare in due modi: propiamente e comunemente. Propiamente, quando si distingue da la scienza e da tutti gli altri abiti intellettivi [...] Comunemente, si piglia in più modi, perciocché alcuna volta si chiamano arti ancora tutte le scienze, senza aggiugnervi o buone o liberali o nobili o altro epiteto alcuno, come si può vedere nel primo libro dell'Anima; et in questo modo tanto significa arte quanto scienza”. Varchi, "Della maggioranza e nobiltà dell'arti”, en Tratatti d'arte del Cinquecento, ed. Barocchi, I3. Leonardo implícitamente asume el sentido más alto y comprensivo del arte, sin aceptar que — como subrayará Varchi- su fin "non è conoscere et intendere, ma fare et operare" (Varchi, "Della maggioranza e nobiltà dell'arti", Tratatti d'arte del Cinquecento, ed. Barocchi, 7), sino, por el contrario, que es tanto "conocer" como "operar".

I84. Da Vinci, Libro di Pittura, $\$ 33$, I56 [ca. I500].

I85. Es un proceso simultáneo reflejado como tal en el despliegue teórico-artístico de Leonardo; según sugiere Kemp, con el ahondamiento de sus investigaciones científicas ocurre también un deslinde de la naturaleza discernible de modo científico y la "sobrenaturaleza" divina; así, su obra tardía, como el San Juan Bautista o La virgen, el niño y santa Ana (si 
como el privilegiado instrumento de la cognición anímica, teniendo siempre fija su mirada autoconsciente en la finalidad misma del arte: su representación sensible. En la fecunda órbita de su despliegue constituyen, de hecho, puntuales antecedentes para las pretensiones filosóficas que respecto de la pintura defenderán, de manera más prolija y con más marcada tendencia idealista, autores como Lomazzo o Zuccaro en el manierismo y sus transformaciones barrocas. Por supuesto, las notas magistrales de Leonardo serán seminales para esos intentos ${ }^{186}$ y suman, a su compacta y vigorosa enunciación, el brillante despliegue de su obra dibujística y pictórica como justificación original y última de tales esbozos teóricos. La phantasía, que presenta aquí de modo primario su faceta como sensus communis, se caracteriza como aprehensión interna de lo sensible tanto como construcción interna de la inventio artística; a un mismo tiempo, se esboza a su través la tensa dialéctica entre el ojo sensible/el ojo imaginario y su unidad en la visión como expresión del fenómeno y acto de la conciencia. Sus poderes pasivos y creativos, cuyo deslinde, en efecto, ha sido ya esbozado en diversas consideraciones de la tradición, habrán de ser replanteados y ahondados por la estética en momentos posteriores (como muestra, de manera nítida, el distingo hegeliano entre Einbildungskraft y Phantasie).

\section{El Leonardo fantástico}

Según muestran sus apuntes teóricos, Leonardo encareció la capacidad de la pintura para conocer y representar las cosas del mundo, pero no evadió destacar su capacidad "imaginaria” e innovadora, donde la phantasía transciende el

acaso es datable más cerca de I5IO-I5I3), puede mostrar "his growing concern to evoke the 'otherness' of spiritual power". Martin Kemp, "Dissection and Divinity in Leonardo's Late Anatomies", Journal of the Warburg and the Courtauld Institutes 35 (I972): 2I 2-213.

186. Por ejemplo, Lomazzo registra su manejo — testimoniado también por Guido Mazenta - de textos de Leonardo, al menos, de un libro escrito por éste "di mano stanca a prieghi di Lodovico Sforza, duca di Milano" sobre la mayor nobleza de la pintura o la escultura. Gian Paolo Lomazzo, Trattato dell'arte della pittura, scoltura et archittetura (II, XIv), en Scritti sulle arti, ed. Roberto Paolo Ciardi, vol. 2 (Florencia: Centro Di, 1974), I38. Pedretti conjetura que la lacuna en el texto de la Giuntina sobre la vida de Leonardo escrita por Vasari, que toca al nombre del "pittore milanese" poseedor de algunos escritos leonardescos (Vasari, Le Vite, 37), corresponde justamente a Lomazzo; véase la "Introduzione” a Leonardo, Libro di Pittura, 49-5I y 54-55. 
status presencial del sensus communis. Por ejemplo, a través de la obra de Apeles ya invocada como ejemplar por Alberti: "Y podrá decir algún poeta: haré una ficción que significa cosas grandes; esto mismo hará el pintor, como hizo Apeles la Calumnia"; ${ }^{87}$ modelo que no dejó de seguir en la práctica, según muestran, entre muchos otros ejemplos, las alegorías vincianas de Óxford. ${ }^{188}$ Se trata sin duda de una modalidad de invenciones que le ocupó no poco de su tiempo y energía. ${ }^{89}$ En otra nota, afirma que el pintor tiene en la mente y realiza con la mano cualquier cosa existente en el universo "por esencia, presencia o imaginación"; en ese mismo locus, pondera su capacidad para representar la belleza y también la fealdad: "Si el pintor quiere ver bellezas que enamoren, es señor para generarlas, y si quiere ver cosas monstruosas que espanten, o que sean bufonescas y risibles, o verdaderamente compadecibles, es él señor y dios". ${ }^{190}$ Esta afirmación se extiende a diversas modalidades de representación y los distintos efectos que producen, pero es notable el énfasis en las cosas "monstruosas" o "ridículas" en las cuales el artista es "señor y dios". No puede dejar de destacarse la dedicación de Leonardo a estas figuraciones, así

I87. "E potrà dire uno poeta: io farò una finzione che significa cose grande; questo medesimo farà il pittore, come fece Apelle la Calunnia". Da Vinci, Codex Atlanticus, 99r-v, en Da Vinci, Scritti scelti, 204; The Literary Works, ed. Richter, $\$ 654$; y Da Vinci, Libro di Pittura, \$ I9, I43 [ca. I 492].

I88. Da Vinci, Oxford (Óxford: Christ Church), 2r-v, en Da Vinci, Scritti scelti, 9I-92; The Literary Works, ed. Richter, \$ 676-677. "Il Piacere e il Dispiacere", "Il Mal Pensiero con l'Invidia, overo Ingratitudine", "Virtú che partorisce contra di sé l'Invidia”, descritas por Lomazzo (Trattato dell'arte della pittura, VI, LV, ed. Ciardi, 390-39I), de acuerdo con la atinada identificación de Carlo Pedretti, "Leonardo's Allegories at Oxford Explained by Lomazzo", The Burlington Magazine 96, núm. 6I5 (junio, I954): I75-I77. Como anota el editor de Lomazzo (Trattato dell'arte della pittura, ed. Ciardi, 390, n. I), el tratadista milanés no adjudica sino "La Calumnia" y "La Envidia" a Apeles, dejando sin atribución las alegorías copiadas de Leonardo.

I89. Según recuerda Clark (I952), 84: "Much of Leonardo's time was spent on the invention of allegories and emblems expressive of Ludovico's greatness. This work seems to have appealed to him, for the manuscripts contain many fabulous or allegorical writings". Véase Martin Kemp, "Leonardo da Vinci: Science and Poetic Impulse" ("The Selwyn Brinton Lecture"), Journal of the Royal Society of Arts (Londres) I33, (I985): I96-2 I 4; Marco Versiero, "Il Moro cogl'occhiali...: Le allegorie politiche di Leonardo da Vinci (Firenze/Milano, I48II494)", Pittura Antica, Oltre lo Sguardo 2, 6 (Ferrara) (2006): 6-20; Joost Keizer, "Leonardo and Allegory", Oxford Art Journal 35, núm. 3 (2012): 433-455.

190. "Se 'l pittore vol vedere bellezze che lo innamorino, lui è signore di generarle, e se vol vedere cose mostruose che spaventino, o che sieno buffonesche e risibili, o veramente compassionevole, lui n'è signore e dio". Da Vinci, Libro di Pittura, \$ I3, I38 [ca. I490-I 492]. 
en un apunte que instruye sobre cómo hacer un "animal ficticio" ("animale finto") a manera de compositum construido sin dejar de lado la brújula del "naturalismo"I9I (que, en efecto, corresponde al modus operandi de la pintura de una especie de dragón descrito por Vasari), ${ }^{192}$ donde se asume — aplicando lo en otro punto señalado, en un contexto científico- que el hombre "produce infinitos compuestos" a partir de los entes "simples" de la naturaleza. ${ }^{193}$

Es también célebre la inclinación del artista hacia diversas "extravagancias" —o lo "fantastico"— ${ }^{194}$ referidas por el mismo biógrafo ("infinite... pazzie"),

19I. "Tu sai non potersi fare alcuno animale, il quale non abbi le sua membra che ciascuno per sé ha similitudine con qualcuno delli altri animali; adunque, se vòli fare parere naturale uno animale finto da te, — diciamo che sia uno serpente, — piglia per la testa una di maschino o bracco, e per li occhi di gatta, e per li orecchi d'istrice, e per lo naso di veltro, e ciglia di lione e tempie di gallo vecchio, collo di testudine d'acqua" "CCome debi fare parere naturale l'animale finto"). Da Vinci, Codex Atlanticus, Iogr, en Da Vinci, Scritti scelti, 228; y The Literary Works, ed. Richter, $\$ 585$. Véase Kemp, Leonardo da Vinci: The Marvellous Works, I 46.

192. "Portò dunque Lionardo per questo effetto ad una sua stanza, dove non entrava se non egli solo, lucertole, ramarri, grilli, serpe, farfalle, locuste, nottole ed altre strane spezie di simili animali; dalla moltitudine de'quali variamente adattata insieme cavò un animalaccio molto orribile e spaventoso, il quale avvelenava con l'alito e faceva l'aria di fuoco; e quello fece uscire d'una pietra scura e spezzata, buffando veleno dalla gola aperta, fuoco dagli occhi, e fumo dal naso sì stranamente, che pareva monstruosa ed orribile cosa affatto: e penò tanto a farla, che in quella stanza era il morbo degli animali morti troppo crudele, ma non sentito da Lionardo per il grande amore che portava all'arte". Vasari, "Lionardo da Vinci, pittore e scultore fiorentino", en Le Vite, 24. En este mismo ámbito de creaciones está la inconclusa "cabeza de Medusa" de la que da asimismo cuenta Vasari, "la più strana e stravagante invenzione che si possa immaginare mai". Vasari, "Lionardo da Vinci", 25. Paul Valéry destacará esta capacidad de Leonardo: "Il a le secret de composer des êtres fantastiques dont l'existence devient probable, où le raisonnement qui accorde leurs parties est si rigoureux qu'il suggère la vie et le naturel de l'ensemble". Introduction à la méthode de Léonard de Vinci (París: Éditions de la Nouvelle Revue Française, 1919), 72.

193. Habla en tal pasaje, en primer término, de las "infinitas" impresiones visuales y auditivas, luego, en particular, de los "semplici e composti" de un lenguaje, multiplicables también de modo ilimitado: "noi diren tali linguaggi essere stati e ancora dovere essere d'infinita varietà, mediante l'infiniti secoli che nello infinito tempo si contengano"; así, el hombre, "massimo strumento di natura", se diferencia de la producción constante de la "especies" de ésta: "perchè la natura sol s'astende alla produzion de' semplici, ma l'omo con tali semplici produce infiniti composti, ma non ha podestà di creare nessun semplice, se non un altro sè medesimo, cioè li sua figlioli”. Da Vinci, Codex Windsor, RL 19045, en Da Vinci, Scritti scelti, 495.

194. Usando la palabra en el sentido de un apunte del propio Leonardo: "Giovannina, viso fantastico; sta a Santa Caterina, all'ospedale”. Da Vinci, Codex Forster $\mathrm{II}_{2}, 76 \mathrm{v}$, en Da Vinci, Scritti scelti, 24I; y The Literary Works, ed. Richter, $\$$ I 404. 
aspecto de su personalidad complicado en la perspectiva de sus inmediatos contemporáneos al implicar sus aficiones e invenciones técnico-científicas. Ciertamente, la distancia entre ambos orbes parece difuminarse en el propio "caos" de los manuscritos leonardescos, ${ }^{195}$ del modo en que la pasión científica sobre los "misterios de la naturaleza" quedó expresada también en "allegorical fantasies on the natural world" componiendo las dos caras —una objetiva, otra imaginaria - de una misma medalla artística. ${ }^{196}$ Luego, la imagen de un Leonardo "fantasioso" se extendió en el periodo renacentista-barroco igualmente vinculada, en efecto, con sus propias indagaciones de perspectiva y anatomía, según muestra una alusión de Zuccaro, quien desestimó las enseñanzas de Dürer y las de "otro excelente hombre de la profesión, pero él también demasiado sofístico, en dejar así preceptos matemáticos para mover y torcer la figura, con líneas perpendiculares, con escuadra y compases; cosas todas ciertamente de ingenio, pero fantástico y sin fruto de substancia”. ${ }^{197}$

195. "Many of the manuscript pages are Leonardo's illustrated notes on scientific research, and they overlap the character of the more deliberate drawings when angels or Madonnas or monsters crowd the margins of machine designs and the diagrams of a bilogist's dissections". Martin Johnson, "Leonardo's Fantastic Drawings I", The Burlington Magazine for Connoisseurs (Londres) 80, núm. 47 I (junio, I942): I42. Nótese que aún Johnson confundía un dibujo del artista con un ejercicio de anatomía fantástica ("Dissected Foot of Monster"), a pesar de que corresponde, según el aviso certero de William Wright ("The Quatercentenary of Leonardo da Vinci. II. Leonard as an Anatomist", The Burlington Magazine for Connoisseurs [Londres] 34, núm. I94 [I9I9]: 203), a la disección de "the hind foot of a plantigrade carnivorous animalprobably a bear" (Codex Windsor, RL I2372-I2375 [ca. I490-I 493]). Con todo, el propio Johnson ha indicado no sin tino que esos ejercicios van más allá de meros "entretenimientos pueriles" e ilustran elocuentemente la "tensión trágica” de la inteligencia leonardesca ante las fisuras del orden del mundo, tanto naturales como — sobre todo- humanas ("Leonardo's Fantastic Drawings II", The Burlington Magazine for Connoisseurs [Londres] 8I, núm. 473 [agosto de 1942], I92-I95); algo estructural a su visión y experiencia de las cosas más allá de los accidentes externos (bien apuntaba Schlosser, Die Kunstliteratur, I50: "Wie bei Michelangelo liegt die Tragik seines Schaffens in ihm selbst, nicht in äußeren Umständen”).

196. Kemp, Leonardo da Vinci: The Marvellous Works, I39 y I46.

197. "altro pur valent'huomo di professione, ma troppo sofistico anch'egli, in lasciare precetti pur mathematici à muouere e torcere la figura, con linee perpendicolari, con squadra, e compassi: cose tutte d'ingegno sì, ma fantastico, \& senza frutto di sostanza”. Zuccaro, L'Idea de' pittori, libro II, 3I [25I]. Pedretti registra en su "Introduzione" este texto de Zuccaro, indicando de modo plausible la identidad de Leonardo detrás de esta alusión; Da Vinci, Libro di Pittura, 42. Para el leonardista, esto es una muestra consecuente en el escenario del debate entre "clasicismo" y "naturalismo" y de la paulatina sustitución academicista de la maestría práctica. Cabe ver en ello, sin embargo, el creciente avance de la renuncia del arte 
Conviene complementar las concepciones ya esbozadas en torno a este tema con un par de conocidas sugerencias que muestran, de un modo quizá más próximo a la comprensión moderna, la vitalidad de la concepción de phantasía en el pensamiento leonardesco. Se trata de dos ejercicios que el pintor juzga válidos y necesarios para el robustecimiento de la interior potencia productora. Uno de ellos lleva el encabezado de "Modo de aumentar o avivar el ingenio para diversas invenciones", y expone lo siguiente:

No dejaré de poner debajo de estos preceptos una nueva invención de especulación, la cual, aunque parezca pequeña y casi digna de risa, no es menos de gran utilidad para avivar el ingenio para varias invenciones. Y ésta es si miras en algunos muros ensuciados con varias manchas o piedras de varias mezclas. Si hallases para 'inventar' cualquier sitio, podrás allí ver semejanzas de diversos paisajes, decoraciones de montañas, ríos, piedras, árboles, grandes llanuras, valles y colinas de diversos modos; aún allí podrás ver diversas batallas y hechos dispuestos con figuras, aspectos extraños de rostros y vestidos y cosas infinitas, las cuales podrás adaptar en entera y recta forma; porque sucede en semejantes muros y mezclas como en el sonido de las campanas, que en sus tañidos encontrarás cualquier nombre o palabra que imaginares.

No es de despreciar este parecer mío, en el cual se te recuerda que no te es inoportuno el quedarte alguna vez a mirar en las manchas de los muros, o en las cenizas del fuego, nubes, lodo u otros lugares similares; si fueren por ti correctamente considerados, hallarás dentro las más maravillosas invenciones, con que el ingenio del pintor se despierta a nuevas invenciones así de composiciones de batallas, de animales y hombres, como de varias composiciones de paisajes y de cosas monstruosas, de diablos y cosas similares, porque fueren causa de darte honor; porque en las cosas confusas el ingenio se aviva para nuevas invenciones. Pero

a su condición de "ciencia" (aún defendida en el clasicismo de Fréart o el barroco postrero por un Palomino) presionada no sólo por su misma praxis sino por el propio poder de la matematización del mundo en el pensamiento científico. Pedretti cita (Da Vinci, Libro di Pittura, 44) un sugestivo apunte de Galileo que muestra a este propósito el abismo de esa "teoría experimental" de los maestros del temprano Renacimiento y el saber operativo (Dialogo [...] sopra i due massimi sistemi del mondo, Tolemaico, e Copernicano, I632 [Florencia: Gio. Batista Landini], 35): "altri posseggono tutti i precetti del Vinci, e non saprebber por dipignere uno sgabello". Ciertamente, la postura de Leonardo es antagónica a la de Michelangelo, quien desdeñaba los intentos de "geometrizar" las artes visuales afirmando la pertinencia del "giudizio dell'occhio", del mismo modo en que aquél — rebajando a la escultura, y de modo contradictorio a otros apuntes suyos - señalaba: "li maestri non si fidano nel giudizio de l'occhio, perché sempre inganna”. Da Vinci, Libro di Pittura, \$36, I 43. 
procura primero saber hacer bien todos las partes de aquellas cosas que quieres figurar, como los miembros de los animales, las partes de los paisajes, es decir, piedras, plantas y similares. ${ }^{198}$

Esta práctica colinda con una de las posibilidades negativas de la phantasía: las falsas figuraciones del sueño y sus derivaciones patológicas en el delirio; a ello alude un pasaje de Aristóteles: "por ello también a los que tienen fiebre algunas veces aparecen animales en las paredes por una pequeña semejanza de las líneas que se juntan" (De insomniis 46obir-I3; ed. W. D. Ross). También se suma a esto el juego de descubrir tornadizas imágenes en las nubes. ${ }^{199}$

198. "Non resterò di mettere [in]fra questi precetti una nova invenzione di speculazione, la quale, benché paia piccola e quasi degna di riso, nondimeno è di grande utilità a destare lo ingegno a varie invenzioni. E quest'è se tu riguarderai in alcuni muri imbrattati di varie macchie o pietre di varii misti. Se arai a invenzionare qualche sito, potrai lì vedere similitudini de diversi paesi, ornati di montagne, fiumi, sassi, alberi, pianure grande, valli e colli in diversi modi; ancora vi potrai vedere diverse battaglie et atti pronti di figure, strane arie di volti e abiti et infinite cose, le quali tu potrai ridurre in integra e bona forma; ch'interviene in simili muri e misti, come del sono delle campane, che tu ne' loro tocchi vi troverai ogni nome e vocabolo che tu t'immaginerai. // Non isprezzare questo mio parere, nel quale ti si ricorda che non ti sia grave il fermarti alcuna volta a vedere nelle macchie de' muri, o nella cenere del foco, o nuvoli, o fanghi, o altri simili lochi, li quali, se ben fieno da te considerati, tu vi troverai dentro invenzioni mirabilissime, che lo ingegno del pittore si desta a nove invenzioni sì di componimenti di battaglie, d'animali e d'omini, come di vari componimenti di paesi e di cose mostruose, come di diavoli e simili cose, perché fieno causa di farti onore; perché nelle cose confuse l'ingegno si desta a nove invenzioni. Ma fa prima di sapere ben fare tutte le membra de quelle cose che voi figurare, come le membra delli animali, come le membra de' paesi, ci[o]è sassi, piante e simili”. Da Vinci, Codex Atlanticus, Io2v, en Da Vinci, Scritti scelti, 2I I-2I2; The Literary Works, ed. Richter, \$ 508; y Da Vinci, Libro di Pittura, \$ 66, I77-I78 [ca. I 492]. El primer párrafo citado es el que corresponde al Codex Atlanticus; el otro añadido, según el editor Pedretti, puede ser posterior a I500.

I99. Continuando, en un pasaje mutilado, sus reflexiones sobre la naturaleza de las apariencias sensibles y su "levedad" ("Nunc age, quam tenui natura constet imago / percipe"), apuntaba Lucrecio esas figuraciones "vacías de sentido" que se forman espontáneamente: "quin potius noscas rerum simulacra vagari / multa modis multis, nulla vi cassaque sensu? / Sed ne forte putes ea demum sola vagari, / quae cumque ab rebus rerum simulacra recedunt, / sunt etiam quae sponte sua gignuntur et ipsa / constituuntur in hoc caelo, qui dicitur aer, / quae multis formata modis sublime feruntur, / ut nubes facile inter dum concrescere in alto / cernimus et mundi speciem violare serenam / aera mulcentes motu; nam saepe Gigantum / ora volare videntur et umbram ducere late, / inter dum magni montes avolsaque saxa / montibus ante ire et solem succedere praeter, / inde alios trahere atque inducere belua nimbos. / nec speciem mutare suam liquentia cessant / et cuiusque modi formarum vertere in oras" 
Recuérdese además que Vasari atribuyó al peculiar Piero di Cosimo (ejemplo negativo de "vita fantastica") la afición de "descubrir" diversas figuraciones en manchas en los muros y las nubes. ${ }^{200}$ Evidentemente, en Leonardo se trata de un acto consciente, como un adiestramiento de la capacidad del artista para descubrir e inventar formas, que estimulan la invenzione del pintor (como se asume también en una crítica contra Botticelli). ${ }^{201}$ Hay evidencias de que un modo de proceder conjeturalmente semejante fue en efecto procurado por Leonardo a partir de sus propios bocetos, que, como ha indicado Gombrich, eran usados “to help his 'invention' regardless of the subject” (así en la Santa Ana, a partir de la Virgen con el gato, o en la búsqueda de soluciones para la Batalla de Anghiari). ${ }^{202}$

En la misma órbita se ubica otro ejercicio a efectuarse "nel letto allo scuro":

He comprobado en mí mismo ser de no poca utilidad, cuando te encuentres a obscuras en el lecho, andar con la imaginativa repitiendo las líneas superficiales de las

(De rerum natura IV, I27-I 42; ed. J. Martin [Leipzig: B. G. Teubner, I969]). O en Filóstrato, dentro de ciertas reflexiones sobre la graphiké entendida como mímesis: "Las cosas que vemos en el cielo', dijo, 'cuando las nubes se separan unas de otras, los centauros y hircocervos y, por Zeus, los lobos y también los caballos” (Vita Apollonii II, xxiı, ed. C. L. Kayser [Leipzig: B. G. Teubner, I870]), sobre las que Apolonio descarta su valor de formas verídicas a menos de imaginar el absurdo de que Dios juega "como los niños en la arena".

200. "Fermavasi talora a considerare un muro, dove lungamente fusse stato sputato da persone malate, e ne cavava le battaglie de'cavagli e le più fantastiche città e più gran paesi che si vedesse mai: simil faceva de'nuvoli dell'aria”. Vasari, Le Vite, I34. Véase sobre ello Sharon Fermor, Piero di Cosimo. Fiction, Invention and "Fantasia" (Londres: Reaktion, I993), I I-40.

20I. Dentro de una anécdota que lo implica y que sirve para ilustrar sus carencias como paisajista, exemplum in malo sobre el tema leonardesco de la universalidad del pintor, se asume la utilidad de las figuras caprichosas en el muro para la invenzione: "Quello non fia universale che non ama equalmente tutte le cose che si contengono nella pittura; come se uno non li piace li paesi, esso stima quelli essere cosa di brieve e semplice investigazione, come disse il nostro Botticella, che tale studio era vano, perché col solo gittare d'una spunga piena di diversi colori in un muro, esso lasciava in esso muro una macchia, dove si vedeva un bel paese. Egli è ben vero che in tale macchia si vede varie invenzioni di ciò che l'om vole cercare in quella, cioè teste d'omini, diversi animali, battaglie, scogli, mari, nuvoli e boschi et altri simili cose; e fa com'il sono delle campane, nelle quali si pò intendere quelle dire quel ch'a te pare. Ma ancora ch'esse macchie ti dieno invenzione, esse non t'insegnano finire nessuno particulare. E questo tal pittore fece tristissimi paesi”. Da Vinci, Libro di Pittura, $\$$ 60, I74 [ca. I 492].

202. Ernst H. Gombrich, “Leonardo’s Method for Working Out Compositions”, en Norm and Form (Londres: Phaidon, I966), 6I. 
formas antes estudiadas, u otras cosas notables por sutil especulación comprendidas, y esto mismo es un acto plausible y útil para conservar las cosas en la memoria. ${ }^{203}$

De esta manera, la mente del pintor es un repositorio de imágenes convocadas por una memoria obligada siempre a robustecer su capacidad evocadora de lo visto, que se convierte también, en la oscuridad, en el tesoro figurativo que resguarda la interioridad. Y, como muestra la práctica anteriormente citada, es también un descubridor de formas, un "visionario" que enriquece y extiende su poder imaginario, su capacidad de fraguar representaciones, en el lúdicro ejercicio de dotar de sentido a lo difuso, de ordenar y animar lo accidental. Poco nos dice esto, es verdad, como en general los textos leonardescos, sobre el "mágico proceso" de su imaginación; ${ }^{204}$ confirman, sin embargo, que, para Leonardo, el pintor es un homo videns como homo imaginans, el que atesora líneas y colores del mundo y que es capaz, desde su visión y su saber interiores, de aprehender las formas de la naturaleza y emularlas a través del arte. \$\$

203. "[Ho in me] provato essere di non poca utilità, quando ti trovi allo scuro nel letto, andare con la imaginativa repetendo i lineamenti superfiziali delle forme per l'addietro studiate, o altre cose notabili da sottile speculazione comprese, [et è] questo proprio un atto laudabile et utile a confermarsi le cose nella memo[r]ia”. Da Vinci, Codex Atlanticus, ro6r, en Da Vinci, Scritti scelti, 220; The Literary Works, ed. Richter, $\$ 496$; y Da Vinci, Libro di Pittura, $\$ 67$, I78 [ca. I 492].

204. Blunt, Artistic Theory in Italy, 38.

N. B. Este texto forma parte de una investigación sobre la phantasía en la literatura artística del Renacimiento y el Barroco realizada con el apoyo de una beca posdoctoral en el Instituto de Investigaciones Estéticas de la UNAM, otorgada por la Coordinación de Humanidades y el Programa de Becas Posdoctorales de la UnAM. 